\author{
UNIVERSIDADE DE SÃO PAULO \\ FACULDADE DE ODONTOLOGIA DE BAURU
}

GUSTAVO LOPES TOLEDO

Enxerto com tubo de polietileno poroso preenchido com gordura autóloga no reparo de nervo periférico: uma nova proposta

BAURU

2011 


\title{
Enxerto com tubo de polietileno poroso preenchido com gordura autóloga no reparo de nervo periférico: uma nova proposta
}

\author{
Dissertação corrigida apresentada a \\ Faculdade de Odontologia de Bauru da \\ Universidade de São Paulo para obtenção do \\ título de mestre em Ciências Odontológicas \\ Aplicadas. A versão original encontra-se \\ disponível no Serviço de Biblioteca da FOB- \\ USP. \\ Área de concentração: Estomatologia e \\ Biologia Oral (opção: Biologia Oral) \\ Orientador: Prof. Dr. Antonio de Castro \\ Rodrigues
}

\section{BAURU}


T575e Toledo, Gustavo Lopes

Enxerto com tubo de polietileno poroso preenchido com gordura autóloga no reparo de nervo periférico: uma nova proposta/ Gustavo Lopes Toledo. Bauru, 2011. p. : il. ; $30 \mathrm{~cm}$.

Dissertação (Mestrado) - Faculdade de Odontologia de Bauru. Universidade de São Paulo

Orientador: Prof. Dr. Antonio de Castro Rodrigues

Autorizo exclusivamente para fins acadêmicos e científicos, a reprodução total ou parcial desta dissertação, por processos fotocopiadoras e outros meios eletrônicos.

Assinatura:

Comitê de Ética da FOB-USP

Protocolo no: 11- 2008

Data: 15.07 .2008 


\section{DEDICATÓRIA}

A MINHA ESPOSA JULIANA MEU GRANDE AMOR, MELHOR AMIGA E VERDADEIRA CONSELHEIRA E A MEU PÁSSARO DE LUZ, MARIA BEATRIZ, QUE POUSOU EM MINHA VIDA JUSTIFICANDO MINHA SENSIBILIDADE, MEUS AMORES A VOCÊS DEDICO MEU TRABALHO 


\section{AGRADECIMENTOS}

A DEUS pela vida e nova oportunidade na terra

A NOSSO SENHOR JESUS CRISTO irmão guia e supremo exemplo

Ao PAPAl, meu guia a quem sinto orgulhoso de chamar de papai, homem vertical, integro, simples, honesto e merecedor de todas as honrarias, estamos unidos para sempre. A MAMÃE como aprendi com você, sei que nossas vidas se entrelaçaram por designíos de Deus e para aprendermos juntos a alegria.

Ao Chico e Divaldo pais espirituais da minha vida talvez nunca saibam como os amo e como foram importantes na minha encarnação.

A meus irmãos JOÃO, FABIANE E RICARDO, como gostaria de estar mais perto de vocês, a providência proverá.

A minha nova família Seu Maurício que me adotou como filho incondicionalmente, Dona Helena, Andrea e Wiliam, por me aceitarem no dia-dia.

Ao Professor Doutor Antonio de Castro Rodrigues, a quem admiro pela incrível capacidade de ter humildade associada a incomparável capacidade técnica. Admiro como possui coração forte para superar as tempestades do destino e ficar de pé como ficou.

Obrigado pela honra de me orientar.

Ao Professor Doutor Clóvis Marzola, meu pai científico, que me ensinou os primeiros passos na academia experimental, o Senhor não sabe quanto me ajudou e como o admiro. 
Ao Professor Doutor Jesus Carlos Andreo que tive a felicidade de conviver intimamente,bem como com sua linda família, muito obrigado.

Ao Professor Doutor Rogério Buchaim que em pouco tempo de contato consegui estreitar laços que certamente permanecerão.

Aos Professores Doutores Marcelo Andretta do Departamento de Física da USP-São Carlos pelo auxílio na execução dos tubos, bem como do Dr. Tadeu, engenheiro e proprietário da ENGIMPLAN, situada na cidade de Rio Claro.

Aos Professores Doutores João Navarro, Flavio, Renato, Marcos Maurício Capelari, Daniel Zorzetto, Claudio Maldonado Pastori pessoas que tenho a honra de conviver e admirar, amigos de caminhada.

Aos meus colegas de pesquisa, que gentilmente me receberam e dedicaram seu precioso tempo em nossa pesquisa, Geraldo, Luiz e Erivam.

Aos colegas de Mestrado Daniel, André, Letícia, Karina, Bruno, Ricardo (primo) e Sandra.

Aos Residentes do Serviço de Cirurgia e Traumatologia Bucomaxilofacial de Bauru, vocês são heróis.

Ao Romário, Orivaldo, Cisira, Fatiminha, Vera (valeu !), vocês são incríveis, ainda bem que a USP os tem!

A Suelen, amiga que cresceu comigo profissionalmente, Cristina, Stela, Dna Judity e Gabriela. 
"A Ciência humana de maneira nenhuma nega a existência de Deus. Quando considero quantas e quão maravilhosas coisas o homem compreende, pesquisa e consegue realizar, então reconheço claramente que o espírito humano é obra de Deus, e a mais notável ." 


\section{RESUMO}

Os nervos periféricos são extensões do sistema nervoso central e responsáveis pela interação das atividades das extremidades, em suas funções sensitiva e motora. São vulneráveis aos mesmos tipos de traumas que afetam outros tecidos: contusão, compressão, esmagamento, estiramento, avulsão e laceração. Desta forma, a interrupção de continuidade da estrutura do nervo, por algum tipo de trauma, resulta na interrupção de transmissão dos impulsos nervosos e na desorganização de suas atividades funcionais. Para tanto, em vista da evolução tecnológica e o desenvolvimento de equipamentos mais sofisticados, a microcirurgia vem ganhando cada vez mais espaço no campo da investigação experimental referente a recuperação de nervos periféricos lesionados. Em uma secção simples, sem perda tecidual, a neurorrafia denominada término-terminal apresenta bons resultados, contudo, quando ocorre perda de tecido nervoso ou, não se têm mais os cotos distais do nervo, outras técnicas devem ser empregadas, até porque, não se pode de modo algum tencionar o nervo numa tentativa de coaptá-lo novamente. Várias técnicas de tubulização utilizando-se materiais biológicos e não biológicos, para criar um meio por onde ocorrerá a regeneração nervosa já foram ou ainda estão sendo testados com resultados insatisfatórios sob o aspecto funcional.É sabido que em um trauma sem perda tecidual, numa neuropraxia, por exemplo, o nervo recupera espontaneamente de forma satisfatória. É sabido também que em um feixe vásculo-nervoso, o nervo periférico encontra-se em íntimo contato com a adventícia de artérias e veias. A adventícia dos vasos é constituída por tecido conjuntivo frouxo, rico em adipócitos. Assim, em um trauma, os neuritos oriundos do coto proximal do nervo lesado, ficam diretamente em contato com esses adipócitos. Seguindo este raciocínio, e com base em trabalhos anteriores onde foi usada veia preenchida com músculo esquelético a fresco como enxerto, decidimos testar a possibilidade de crescimento axonal por meio de enxerto com tubo de polietileno preenchido por tecido adiposo autólogo. Para tanto será utilizado um tubo com $12 \mathrm{~mm}$ de comprimento por $0,25 \mathrm{~mm}$ de diâmetro, com poros de $80 \mu \mathrm{m}$ de diâmetro, preenchido com tecido adiposo in natura retirado das adjacências do referido nervo, na tentativa de se recuperar o nervo isquiático. A certificação do 
sucesso da recuperação do nervo será feita por meio de técnicas de microcirurgia, microscopia e morfometria. O enxerto de polietileno mostrou ter resistência a pressões, uma vez que não foi observado colapso estrutural. A gordura mostrou ser bom material trófico já que no grupo onde a utilizou apresentou resultados mais próximos do controle final.

Palavras-chave: Nervo isquiático de ratos, regeneração axonal, tubo de polietileno poroso. 


\begin{abstract}
Peripheral nerves are extensions of the central nervous system and are responsible for the interaction of the activities of the extremities in their sensory and motor function. They are vulnerable to these types of injuries that affect other tissues: contusion, compression, crush, stretch, tear and avulsion. Thus, the interruption of continuity of the nerve structure, due to some sort of trauma, results in the interruption of transmission of nerve impulses and disruption of their functional activities. Therefore, in view of technological evolution and development of more sophisticated equipment, microsurgery is gaining more space in the field of experimental research concerning the recovery of injured peripheral nerves. In a single section, without loss of tissue, called the endterminal neurorrhaphy was also good, however, when there is loss of nervous tissue or, if not longer have the distal nerve stumps, other techniques must be employed, because, in any circumstance the nerve should be tensioned as an attempt to coaptation again. Several techniques of tubing, using biological materials and non-biological means to create a place where nerve regeneration have been or are still being tested with unsatisfactory results in the functional aspect. It is known that in a trauma without loss of tissue, a neuropraxia, for example, the nerve recovers spontaneously and satisfactorily. It is also known that in a neurovascular bundle, the peripheral nerve is in close contact with the adventitia of arteries and veins. The adventitia of the vessels is composed of loose connective tissue rich in adipocytes. Thus, in trauma, the neurites from the proximal stump of injured nerve, are directly in contact with these adipocytes. Following this reasoning, and based on previous work where it was used vein filled with fresh skeletal muscle as a graft, decided to test the possibility of axonal growth by grafting polyethylene tube filled with autologous adipose tissue. For that will be used with a tube $12 \mathrm{~mm}$ long and $0.25 \mathrm{~mm}$ in diameter, with pores of 80 microns in diameter, filled with fresh adipose tissue removed from the vicinity of that nerve, in an attempt to recover the sciatic nerve. Certification of successful nerve recovery will be done through microsurgical techniques, microscopy and morphometry. The graft polyethylene
\end{abstract}


proved to have pressure resistance, since no structural collapse was observed. The fat was found to be good material as trophic group which had used the results closer to the ultimate control.

Keywords: rat sciatic nerve, axonal regeneration, porous polyethylene pipe. 


\section{LISTA DE ILUSTRAÇÕES}

\section{- FIGURAS}

Figura 1 - Esquema de um neurônio e seus anexos 32

Figura 2 - Detalhe da várias camadas de mielina num corte em grande aumento de uma fibra nervosa.Corte de microscopia eletrônica de transmissão .32

Figura 3 - Representação esquemática de um Oligodendrócito (seta).

Figura 4 - Imagem esquemática de um nervo nota-se a presença do epineuro (seta) 33

Figura 5 - Imagem demonstrando correto condicionamento dos animais em caixas apropriadas 55

Figura 6 - Demonstração esquemática do tubo de Polietileno Poroso .57

Figura 7 - Demonstração esquemática do tubo de Polietileno Poroso 58

Figura 8 - Exemplar do anestésico utilizado nos procedimentos cirúrgicos.

Figura 9 - Realização de tricotomia na face lateral do membro inferior direito do rato 59

Figura 10 - Animal com as patas fixadas na placa de cortiça com auxilio de fitas adesivas. 
Figura 11- Incisão de $2 \mathrm{~cm}$ na face lateral da coxa direita do animal.

Figura 12 - Após a incisão e divulsão dos tecidos subcutâneos

e musculatura subjacente, nota-se exposição do nervo isquiático.

Figura 13 - Aspecto do tubo de Polietileno poroso podemos comparar seu tamanho com uma lamina de bisturi número 11 61

Figura 14 - Demonstração da remoção da gordura in situ que, posteriormente, foi utilizada no grupo experimental com preenchimento. 61

Figura 15 - Em A - Vista aproximada do tubo de polietileno poroso, podemos notar a espessura de sua parede; Em B - Imagem revelando a inserção da gordura autógena no interior do tubo do grupo de enxerto experimental com preenchimento; Em C - Gordura inserida em recipiente com soro fisiológico $0,9 \%$ 62

Figura 16 - Verificamos por esta tomada a correta colocação do tecido adiposo, sem obliterar totalmente o lume do tubo de polietileno. .63

Figura 17 - Nervo isquiático após a lesão cirurgicamente provocada .63

Figura 18 - Tubo do grupo GEEP-CG, fixado em suas extremidades com nylon 10.0, nota-se também, por transparência a presença da gordura recostada na parede lateral do tubo .64 
Figura 19 - Nota-se paralisia da pata direita do animal do grupo GEEP-CG

Figura 20 - Incisão realizada na face lateral da coxa direita do animal do grupo Experimental de Enxerto com preenchimento nota-se densa formação de tecido conjuntivo circundando o tubo de polietileno poroso. Para melhor exposição da estrutura nervosa utilizamos fita de látex .70

Figura 21 - Após a remoção do tubo do sitio cirúrgico, observamos o tubo densamente colonizado por tecido conjuntivo

Figura 22 - Animal do grupo Experimental de enxerto com preenchimento com gordura, observa-se evidente sinal macroscópico de regeneração nervosa, com a clássica forma de ampulheta 71

Figura 23 - Animal do mesmo grupo Experimental da foto anterior, contudo observa-se ausência de regeneração em ampulheta .71

Figura 24 - Imagem histológica em aumento de 40x demonstrando que não houve boa fixação com o tetróxido de Ósmio na porção central do nervo isquiático

Figura 25 - Em A: GEEPcg150, em B: GEEPsg150, em C: GCl, em D: GCF, note as fibras mielínicas (seta cinza) , amielínicas (seta branca) 73

Figura 26 - Autofagia do animal do Grupo controle desnervado. .74 
Figura 27: Representação gráfica da média das áreas das fibras nervosas do nervos Isquiático

Figura 28: Representação gráfica da média da área dos axônios do nervo Isquiático 76

Figura 29: Representação gráfica da média do diâmetro fibras nervosas do nervos Isquiático. 77

Figura 30: Representação gráfica da média do diâmetro dos axônios

Figura 31: Representação gráfica da área das Bainhas de mielina do nervo Isquiático 79

Figura 32: Representação gráfica da Espessura das Bainhas de Mielina do nervo Isquiático. 80

Figura 33: Imagem representando as fibras nervosas do nervo Isquiático dos grupos $\mathrm{GCl}, \mathrm{GCF}$, GEEPcg \& GEEPsg da esquerda para direita respectivamente, considerando todas as variáveis possíveis 


\section{LISTA DE TABELAS}

Tabela 1: Distribuição dos ganhos de massa iniciais, médias

e finais. 


\section{LISTA DE QUADROS}

Quadro 1: Classificação histopatológica das lesões nervosas periféricas segundo Seddon e Sunderland.

Quadro 2: Correlação entre o tipo, grau e extensão da lesão nervosa e sua regeneração.

Quadro 3: Distribuição dos ganhos de massa iniciais, médias e finais.

Quadro 4 : Dados morfométricos referente ao nervo Isquiático $(\mathrm{N}=220)$. Onde: $\mathrm{AF}=$ Área da Fibra, $\mathrm{AA}=$ Área do Axônio, DF=Diâmetro da Fibra, DA= Diâmetro do Axônio, $A B=$ Área da Bainha e EB= Espessura da Bainha

Quadro 5: Dados referentes as médias dos valores colhidos das marchas dos animais. .81 


\section{LISTA DE SIGLAS E ABREVIATURAS}

$\mathrm{cm}:$ Centímetro

EMV: Eletromiografia

mm: Milímetro

MET: Microscopia Eletrônica de Transmissão

g: Gramas

GCl: Grupo controle inicial

GCD: Grupo Controle Desnervado

GCF: Grupo Controle Final

GEEPsg150: Grupo Experimental Enxerto com Tubo de Polietileno poroso sem gordura

GEEPcg150: Grupo Experimental Enxerto com tubo de Polietileno poroso com gordura

SF: Soro Fisiológico

N.: nervo

PAC: Potencial de Ação Composto (PAC)

PLA: Polilactina

PGA: Poliglicólico

PHB: Polifosfoésteres

$\mu \mathrm{m}$ : micrômeros 


\section{SUMÁRIO}

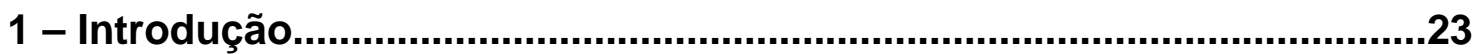

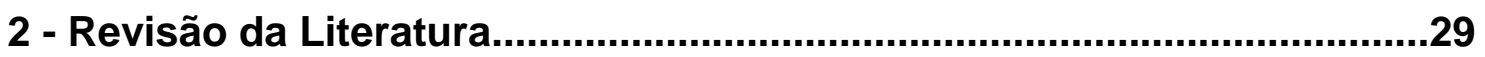

2.1 - Considerações morfológicas dos neurônios e nervos................................................................

2.1.1 - Neurônios..................................................................

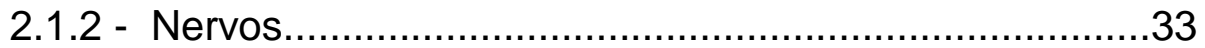

2.2 -Principais causas das lesões nervosas....................................34

2.3 - Classificação das lesões dos

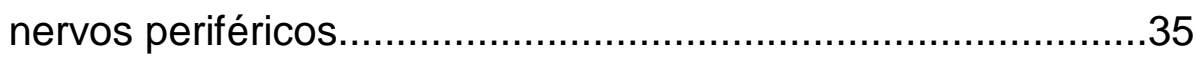

2.3.1 - Seguindo a classificação do

Sir Hebert Seddon (1943)...........................................35

2.3.1.1 - Neuropraxia............................................. 35

2.3.1.2 - Axonotmese.................................................

2.3.1.3 - Neurotmese ...................................................

2.3.2 - Sistema de Sunderland...............................................36

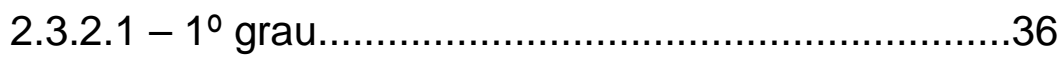

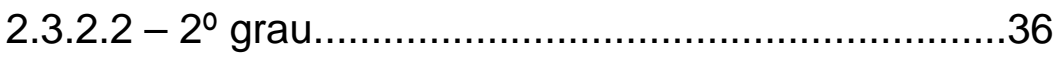

2.3.2.3 - $3^{\circ}$ grau.........................................................

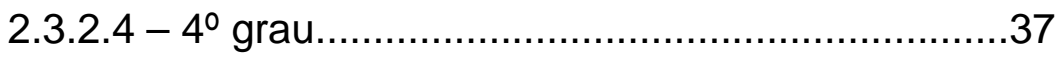

2.3.2.5 - 5o grau.........................................................

2.4 - Alterações Histológicas após as lesões

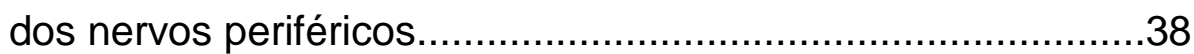

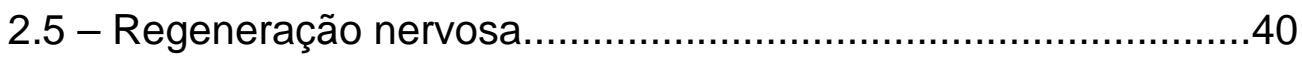

2.6 - História atualidade da cirurgia em nervos periféricos.

2.6.1 - A evolução do tratamento das

lesões dos nervos periféricos........................................41

2.6.2 - Atualidade no tratamento das lesões dos nervos periféricos.......................................43

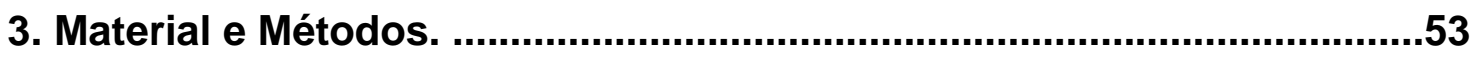

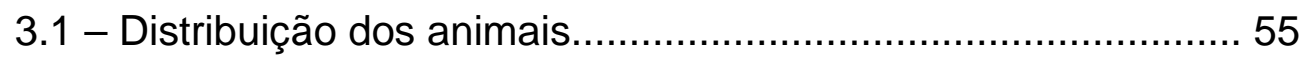

3.1.1 - Grupo Controle Inicial (GCl ) ...................................56 
3.1.2 - Grupo Controle Final (GCF - 150).

\subsection{3 - Grupo Controle Desnervado}

$$
\text { (GCD - 150) }
$$

3.1.4 - Grupo Experimental Enxerto de

Polietileno sem gordura

$$
\text { (GEEPsg - 150). }
$$

3.1.5 - Grupo Experimental Enxerto de Polietileno com gordura (GEEPCG - 150).

3.2 - Características morfológicas dos tubos de polietileno poroso.

3.3 - Procedimentos cirúrgicos e coleta das amostras 58

3.4 - Análise funcional do nervo isquiático. .64

3.5 - Processamento histológico dos nervos (isquiáticos)

3.6 - Processamento para análise morfométrica............................65

3.7 - Forma de análise dos resultados...........................................65

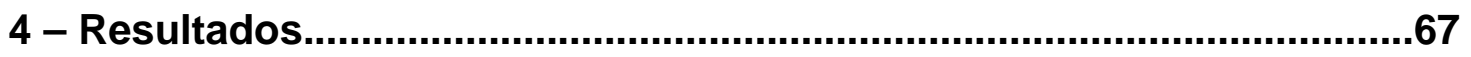

4.1 - Observações externas.................................................69

4.2 - Procedimentos cirúrgicos...............................................69

4.3 - Observações histológicas.............................................72

4.4 - Pesos dos animais..........................................................74

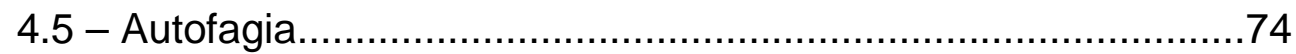

4.6 - Aspectos morfométricos dos nervos.................................75

4.7 - Análise funcional do nervo isquiático.................................81

5 - Discussão..........................................................................................83

6 - Conclusões...............................................................................................91

Referências Bibliográficas................................................................97

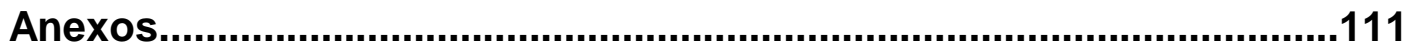



1 - Introdução 

Um nervo periférico assemelha-se a um cabo condutor de eletricidade. Trata-se de uma estrutura que terá a função de carregar impulsos nervosos da medula até os músculos e também, em sentido inverso, de transmitir informações nervosas vindas da pele, músculo, articulações e órgãos internos até a medula. Assim, no caso de lesão, todos os músculos inervados por esse nervo sofrerão paralisia e uma parte da pele por ele inervada poderá ficar anestesiada, por vezes tornando o indivíduo impossibilitado de realizar suas atividades (LECH, 1990).

As possíveis causas de destruição parcial de fibras nervosas são as (1) traumáticas, por meio dos acidentes automobilísticos, desportivos, de trabalho, quedas, pancadas, ferimentos causados por arma branca, projéteis, agressões físicas entre outros, (2) neoplásicas quando associada ao desenvolvimento de tumores e as (3) iatrogênicas (CUNHA et al., 2007).

As lesões dos nervos periféricos podem ser subdivididas, de acordo com a classificação de Seddon (1943), em neuropraxia, sendo a forma mais branda de lesão nervosa, caracteriza-se por uma redução ou bloqueio completo da condução através de um segmento de nervo com a continuidade axonal conservada, na maioria dos casos não há necessidade de tratamento. Axoniotmese é decorrente de uma lesão dos axônios com preservação das estruturas de sustentação, o tecido conjuntivo neural, desta forma a arquitetura interna fica relativamente preservada, podendo orientar a regeneração axonal. E, por fim a neurotmese, que consiste na ruptura completa do axônio e das estruturas que o sustentam (GRANT, 1999).

No caso das neurotmeses várias técnicas microcirúrgicas já foram descritas com sucesso, em especial onde não houve perda tecidual e sim, um simples seccionamento. Uma simples sutura término-terminal, também chamadas de neurorrafia, na região epineural já é suficiente. A primeira neurorrafia foi conduzida por William de Saliceto no século XIII, na Bolonha, mas os princípios técnicos dos reparos de nervos periféricos fundamentam-se nas observações de Waller do século XIX, sobre a regeneração do coto distal e as projeções (sprouting ) dos axônios a partir do coto proximal do nervo lesado.

Porém, secções com formação de gap maiores que $3 \mathrm{~cm}$ são inadequadas para simples conexões, sendo mais indicado o enxerto autólogo de 
um nervo sural, por exemplo (SUNDERLAND, 1978; HUDSON et al., 1979). Limitações do calibre do nervo lesado levam a utilização dos chamados "cable grafts", em que diversos segmentos do nervo são utilizados. A grande desvantagem é a necessidade de um grande número de suturas, consequentemente aparecimento de cicatrizes. Igualmente, a área doadora terá déficit de sensibilidade (FAWCET et al., 1986; MAGILL et al., 2007). Para resolver essa celeuma um grande número de pesquisadores pelo mundo tem vertido seu tempo em busca de novos caminhos, tais como, a pesquisa que envolve a utilização de materiais biológicos e não biológicos que serviram de elementos condutores da regeneração das fibras nervosas. Para tanto, foram propostos materiais colágenos, artérias, veias, moléculas de adesão celular, tubos de Polietileno (FIELDS et al., 1989).

Grandes avanços com a utilização de veia invertida tem se notado, especialmente porque ao se inverter a veia há exposição da túnica adventícia ao contato direto com os axônios seccionados, tornando-se um bom conduto para a regeneração de nervos. Além de serem permeáveis a fatores externos, encontram-se ricos em fatores tróficos, como colágeno, laminina e fibronectina, com proporções ideais, favorecendo um micromeio altamente favorável ao crescimento axonal (FERRARI et al., 1999).

Contudo, a auto enxertia além de não promover total recuperação funcional do nervo lesado, produz alterações na área doadora (SPECTOR et al., 1993; BRUNELLI et al., 1994). Estes problemas abrem caminho para busca de novas técnicas que sejam menos invasivas e mais simples, reduzindo significativamente a morbidade pós-operatória.

Técnicas baseadas no método de tubulização ou entubulização passaram a ser usadas em pesquisas sobre regeneração nervosa. Neste procedimento cirúrgico, os cotos dos nervos seccionados ou lesados são inseridos e fixados em uma prótese tubular com fios ultrafinos, sob atenção de microscópio cirúrgico (OLIVEIRA et al., 2004; TANSEY et al., 2011).

A recuperação do nervo frênico de cães através de enxertos feitos de tubo de colágeno, preenchidos com ácido poliglicólico, foi coberta por retalho de pericárdio rico em adipócitos. Os resultados apresentaram-se bem promissores, 
muito provavelmente, pela ação benéfica do tecido adiposo justaposto (YOSHITANI et al., 2007).

Centros de pesquisa espalhados pelo mundo estão utilizando células tronco extraídas de lipoaspiração. Mesmo porque, tais células dispensam cultivos longos como ocorre com outros tipos de células tronco (D'ANDREA et al., 2008).

Com isso, a presente dissertação propõe a utilização de um tubo de polietileno poroso que funcione como elemento condutor na regeneração de nervo isquiático lesado. Para comparar as diferentes técnicas, em um grupo houve o preenchimento com gordura autógena e em outro grupo ficou sem preenchimento. 
28 1-Introdução 


\section{2 - Revisão da Literatura}





\section{REVISÃO DE LITERATURA}

\subsection{Consideracões Morfológicas dos neurônios e nervos}

\subsubsection{Neurônios:}

As células nervosas ou neurônios são formados por um corpo celular ou pericário, que contém núcleo e do qual partem prolongamentos. Em geral, o volume total dos prolongamentos de um neurônio é maior do que o volume do corpo celular. Possuem morfologia complexa, porém quase todos apresentam três componentes, corpo celular (onde se encontra o núcleo celular), dendritos, axônio e telodendritos, (JUNQUEIRA e CARNEIRO, 2009).

Corpo celular (fig.1) é a zona estrutural do neurônio. Nele podem ser encontrados o núcleo, o citoplasma as organelas e o citoesqueleto. Estão normalmente localizados em áreas restritas do sistema nervoso, que formam o sistema nervoso central ou ainda nos gânglios nervosos, localizados próximo da coluna vertebral.

Dendritos (fig.1) são numerosos prolongamentos dos neurônios especializados na recepção de estímulos nervosos, que podem ser do meio ambiente ou de outros neurônios. A grande maioria dos neurônios possui numerosos dendritos - pois estes aumentam a sua superfície celular, tornando possível receber e integrar impulsos trazidos por numerosos terminais axônios de outros neurônios. Vão afinando-se à medida que se ramificam e não possuem complexos de Golgi. A grande maioria dos impulsos que chegam a um neurônio é recebida por pequenas projeções dos dendritos, de nome espinhas ou gêmulas. Estas são compostas de uma pequena parte alongada do dendrito formada por uma pequena dilatação; a quantidade de gêmulas em cada dendrito varia de um para outro, mas elas são sempre muito numerosas. São o primeiro local de processamento dos impulsos nervosos.

O axônio (fig.1) é uma parte do neurônio responsável pela condução dos impulsos elétricos que partem do corpo celular, até outro local mais distante, como um músculo ou outro neurônio. Uma de suas características é estar envolto pelas células de Schwann, no sistema nervoso periférico, e pelos 
oligodendrócitos (fig.3) no sistema nervoso central. As superposições de camadas de oligodendrócitos e de células de Schwann originam a bainha mielínica (fig. 2). Alguns axônios de neurônios de um humano adulto podem chegar a mais de um metro de comprimento. Cada neurônio possui um único axônio, que nasce do cerne de implantação, localizado ainda na região do pericário do neurônio; os axônios não se ramificam abundantemente, e, quando o fazem, dão origem aos chamados colaterais. A não continuidade da bainha forma espaçamentos isentos de mielina, os nódulos de Ranvier (fig.1). Isto facilita um movimento mais ágil do impulso que vai ocorrendo em saltos, já que o impulso só se propaga com a presença de mielina.

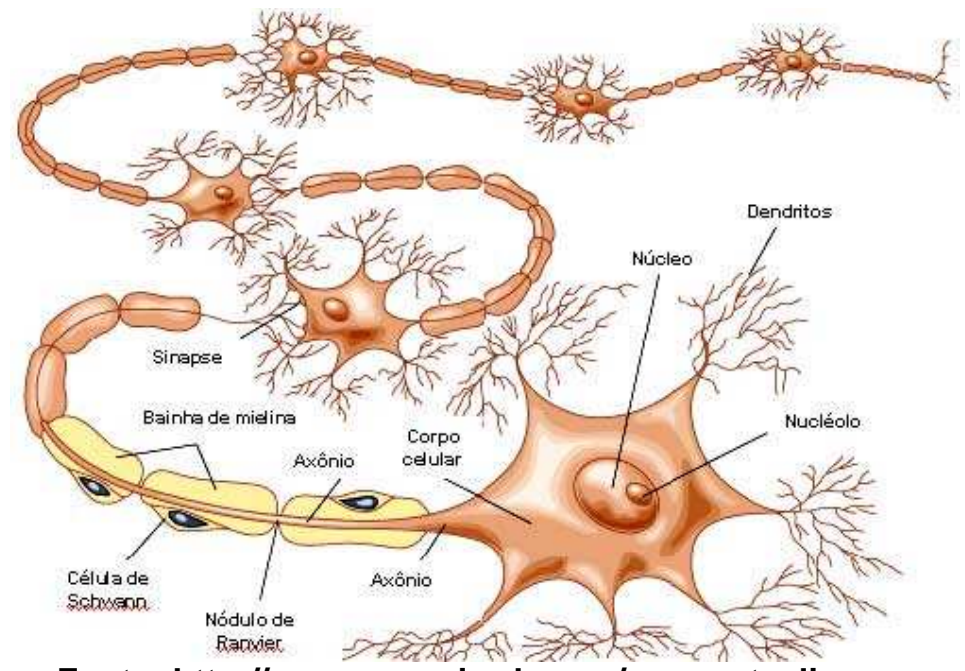

Fonte: http://www.passeiweb.com/na_ponta_lingua

Figura 1: Esquema de um neurônio e seus anexos

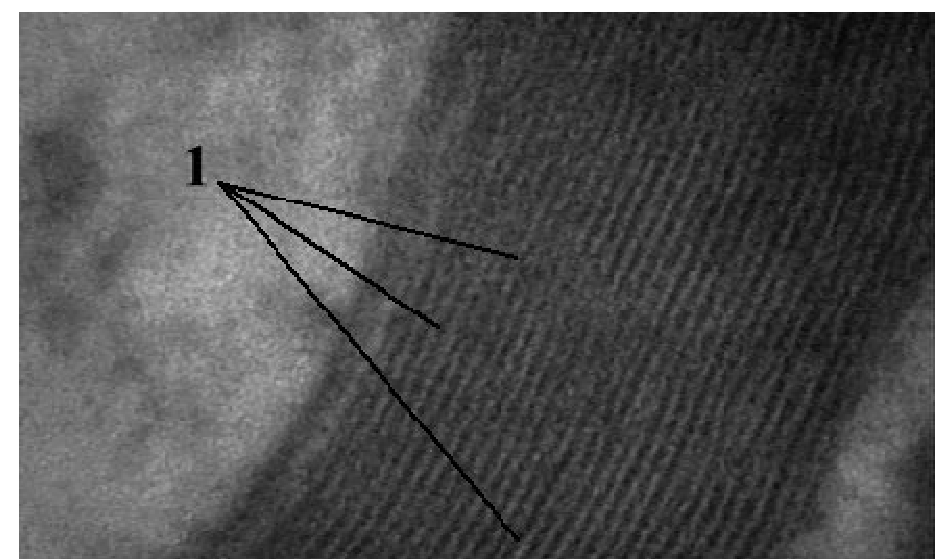

Figura 2: - Detalhe da várias camadas de mielina num corte em grande aumento de uma fibra nervosa. Corte de microscopia eletrônica de transmissão. 


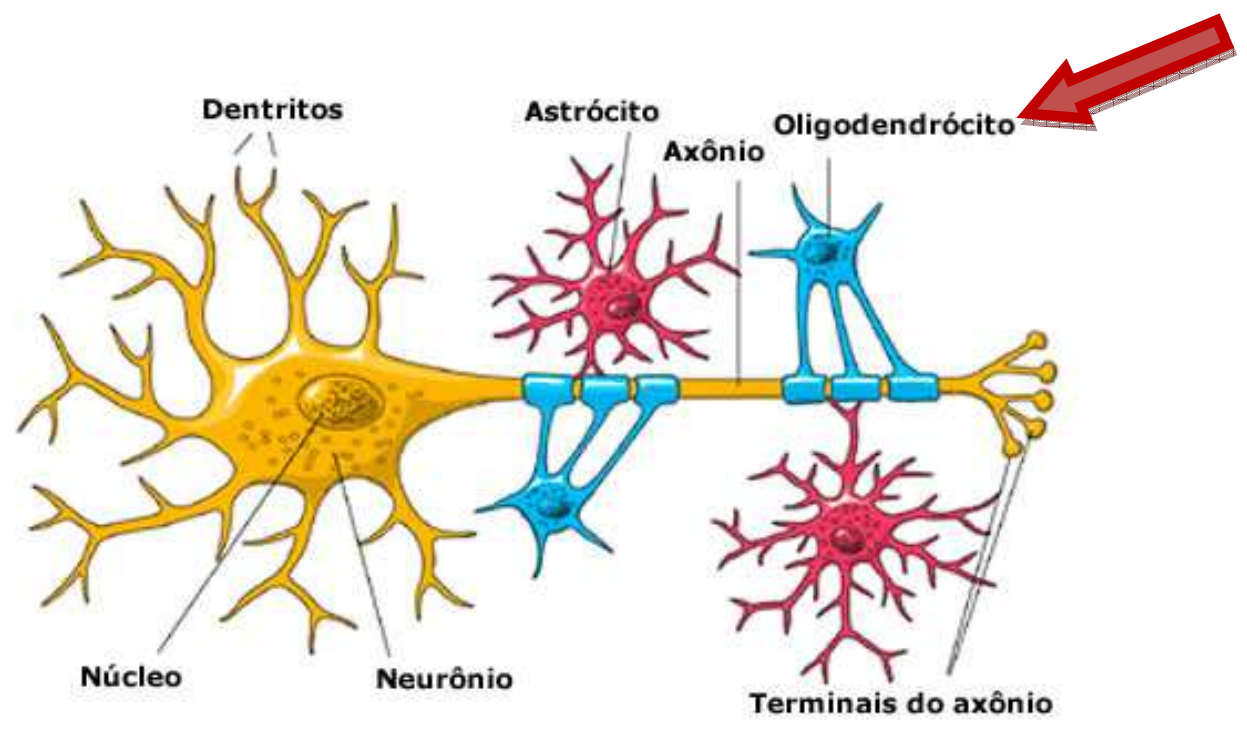

Fonte: http://www.geroupr.com/nervioso.html

Figura 3: Representação esquemática de um Oligodendrócito (seta).

\subsubsection{Nervos:}

No sistema nervoso periférico as fibras nervosas agrupam-se em feixes, dando origem aos nervos. Devido à cor da mielina, os nervos são esbranquiçados, exceto os raros nervos muito finos formados somente por fibras amielínicas. O tecido de sustentação dos nervos é constituído por uma camada fibrosa mais externa de tecido conjuntivo denso, o epineuro (fig.4), que reveste 0 nervo e preenche os espaços entre os feixes de fibras nervosas.

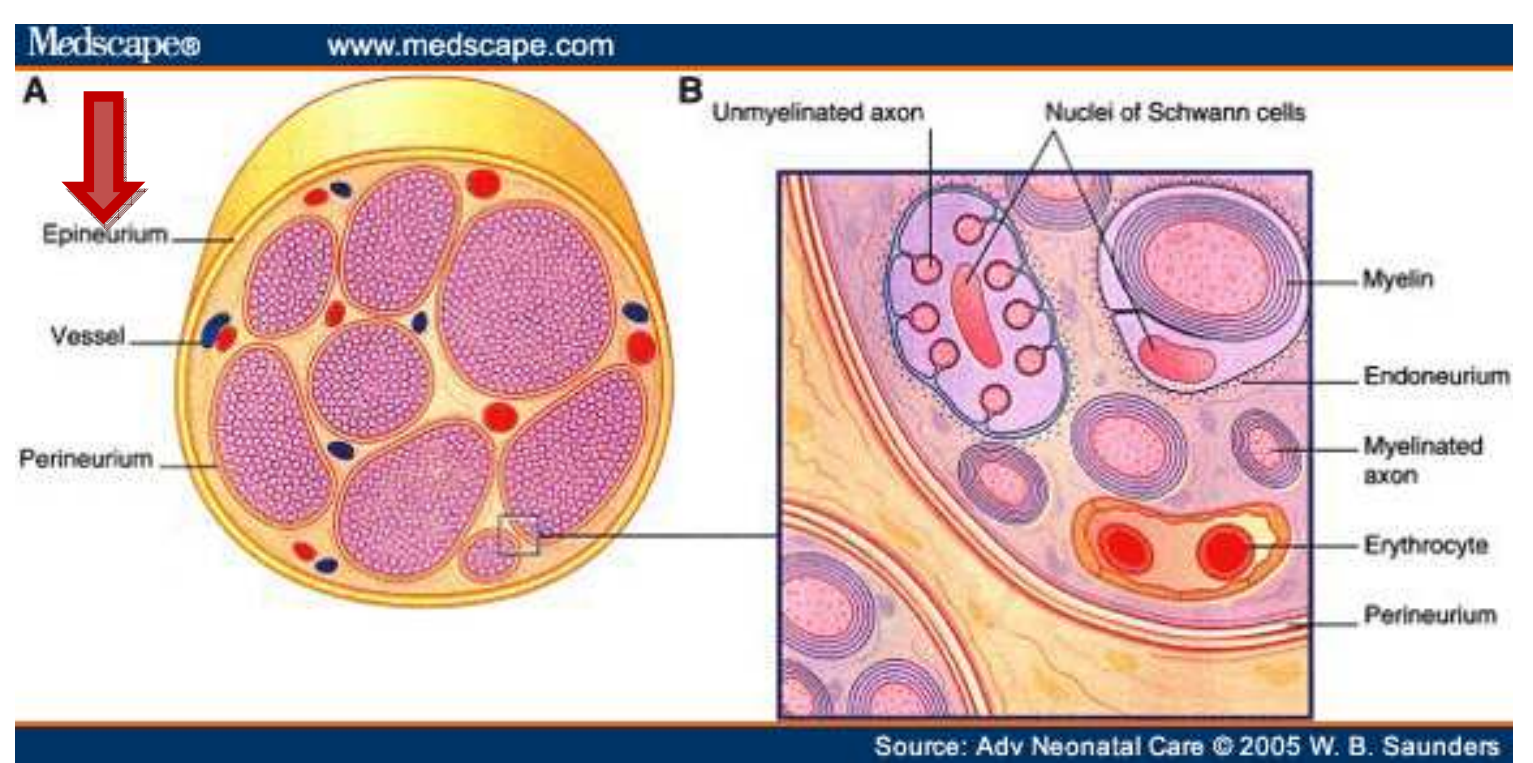

Fonte: www.medscape.com

Source: Adv Neonatal Care 02005 W. B. Saunders

Fig.4: Imagem esquemática de um nervo, nota-se a presença do epineuro (seta). 
Cada um destes feixes é revestido por uma bainha de várias camadas de células achatadas, justapostas, o perineuro. As células de bainha perineural unem-se por junções oclusivas, constituindo uma barreira à passagem de macromoléculas. Dentro da bainha perineural encontram-se os axônios, cada um envolvido pela célula de Schwann, com sua lâmina basal e um envoltório conjuntivo constituído principalmente por fibras reticulares, chamado endoneuro. As células de Schwann sintetizam colágeno tipo III que forma as fibras reticulares do endoneuro. Os nervos estabelecem comunicação entre os centros nervosos e os órgãos da sensibilidade e os efetores. Possuem fibras aferentes e eferentes, em relação ao sistema nervoso central. As aferentes levam para os centros as informações obtidas no interior do corpo e no meio ambiente. As fibras eferentes levam impulsos dos centros nervosos para os órgãos efetores comandados por esses centros. Os nervos que possuem apenas fibras de sensibilidade (aferentes) são chamados de sensitivos e os que são formados apenas por fibras que levam a mensagem dos centros para os efetores são os nervos motores. A maioria dos nervos possuem fibras dos dois tipos, sendo, portanto, nervos mistos.

\subsection{Principais causas das lesões nervosas}

Relatos de lesão aguda do nervo podem ser rastreados até 3500 anos atrás. Na conhecida história bíblica, Jacob sofreu uma lesão no nervo ciático com uma traumática luxação do quadril durante a sua batalha com o anjo (Gênesis 32:25-33). Entretanto, nenhuma técnica específica para reparar dano no nervo periférico foi descrito até o século XVI.

São variadas as causas de lesões de nervos periféricos. Cada vez mais estas lesões tornam-se frequentes na rotina dos atendimentos de urgências dos hospitais em consequência do aumento da violência urbana, dos acidentes automobilísticos, profissionais e domésticos (DE SÁ, 2004; MAZZER, 2006). Acredita-se que cerca de $5 \%$ dos pacientes atendidos em centros especializados em trauma apresentem lesão ou ruptura de um nervo periférico ou plexo (MURRAY, 2005). 
As lesões traumáticas dos nervos periféricos incluem esmagamento, compressão, estiramento, avulsão, secção parcial ou total e podem resultar em comprometimento funcional secundário ao déficit da transmissão de impulsos nervosos no território inervado (MONTE-RASO, 2006). Entre as causas não traumáticas encontramos as infecções virais, afecções inflamatórias, exposição a toxinas, distúrbios metabólicos, tumores e algumas neuropatias hereditárias (BOSCH; SMITH, 2005; ATOLINI JUNIOR, 2009).

Alguns traumas são considerados de natureza invasivas, podendo ser acidentais como lacerações, ferimentos penetrantes, injeções de medicamentos ou danos nervosos durantes procedimentos cirúrgicas ou consideradas manobras necessárias tais como ressecção nervosa ou rizotomia. Inúmeros outros traumas podem ter natureza não invasiva provocando compressão, tração ou esmagamento sobre um nervo e resultando em comprometimento neurológico (KENDALL, 2007). Os nervos podem ainda sofrer lesões por condições físicas extremas como exposição ao frio, corrente elétrica e radiação (MURRAY, 2005).

Os traumas podem ser separados em súbitos ou graduais, sendo que o último como resultado de posições mantidas ou movimentos repetitivos, o envolvimento pode ser disseminado por um membro ou localizado em um único ramo nervoso; pode ainda ser transitório ou resultar em déficits permanentes (KENDALL, 2007).

\subsection{Classificacão das lesões dos nervos periféricos}

\subsection{1 - Seguindo a classificação clássica do Sir Herbert Seddon (1943) das lesões traumáticas dos nervos, estas podem ser:}

\subsubsection{1 - Neuropraxia}

Há interrupção da condução do impulso pelas fibras nervosas, e a recuperação ocorre sem degeneração Walleriana. Esta é a condição mais favorável a recuperação e retorno a normalidade. 


\subsubsection{2 - Axonotmese}

Trata-se de perda da relativa continuidade do axônio e sua cobertura de mielina, mas a preservação da estrutura do tecido conectivo do nervo (o tecido de encapsulamento, o epineuro e perineuro, estão preservados). Como continuidade axonal é perdida, ocorre degeneração Walleriana. A eletromiografia (EMG) realizada 2 a 3 semanas mais tarde mostra fibrilações e potenciais de desnervação na musculatura distal ao local da lesão. Perda de impulso motor e sensorial é mais completo com axoniotmese que com neuropraxia, e a recuperação ocorre somente através de regeneração dos axônios, um processo que requer tempo. Axonotmese é geralmente o resultado de uma queda mais grave.

\subsubsection{3 - Neurotmese}

É mais grave, ocorre em contusão grave, estiramento, lacerações. Não só axônio, mas o tecido conjuntivo encapsular perde continuidade. O último e extremo grau neurotmese é transecção, mas a maioria destas lesões não produzem perda bruta de continuidade do nervo, mas ao invés, ruptura interna da arquitetura do nervo suficiente para envolver perineuro e endoneuro bem como axônios e seus invólucros. A desnervação registrado por EMG são as mesmas que as observadas com lesão axonotméticas. Existe uma perda completa da função motora, sensitiva e autonômica. Se a perda do nervo foi completamente dividida, a regeneração axonal causa um neuroma a se formar no coto proximal. Para neurotmese é melhor usar uma nova classificação, mais completa, chamado Sistema de Sunderland (SEDDON, 1943).

Sunderland expandiu este sistema de classificação para 5 graus de lesão do nervo.

\subsection{2 - Sistema de Sunderland:}


2.3.2.1 - 1ำ Grau: Existe um bloqueio da condução nervosa, sem existir lesão anatômica. A recuperação funcional ocorre entre 1 a 6 semanas depois da lesão. Corresponde à Neuropraxia na classificação de Seddon.

2.3.2.2 - 2 Grau: Existe uma lesão do axónio, embora o tubo endoneural esteja intacto. Tem lugar uma degeneração Walleriana assim como alterações retrógradas no cabo proximal do axônio. A recuperação é mais lenta.

2.3.2.3 - 3o Grau: A lesão limita-se à totalidade da fibra nervosa, com rotura dos axónios e tubos endoneurais, enquanto que Perineuro e o Epineuro permanecem intactos. A recuperação anatómica da lesão assim como a função, será muito incompleta e mais tardia.

2.3.2.4 - 4 Grau: A rotura da fibra é total, e somente o Epineuro ficou intacto. A possibilidade de recuperação espontânea é mínima e descartável, pelo que a lesão deve ser recuperada cirurgicamente.

2.3.2.5 - 5 Grau: A lesão do nervo é total e a recuperação cirúrgica é inevitável, se quiser obter a recuperação da função (SUNDERLAND, 1985).

Na quadro 1 e na tabela 1 observamos uma comparação entre as duas classificações.

Quadro 1: Classificação histopatológica das lesões nervosas periféricas segundo Seddon e Sunderland

\begin{tabular}{|c|c|}
\hline SEDDON & SUNDERLAND (1951) \\
\hline (1943) & Grau 1 - Desmielinização local \\
\hline Neuropraxia & Grau 2 - Interrupção da continuidade axonal \\
\hline Axonotmese & Grau 3 - Destruição do endoneuro \\
Neurotmese & Grau 4 - Destruição do perineuro \\
& Grau 5 - Interrupção da continuidade de todas as \\
& estruturas nervosas \\
\hline
\end{tabular}




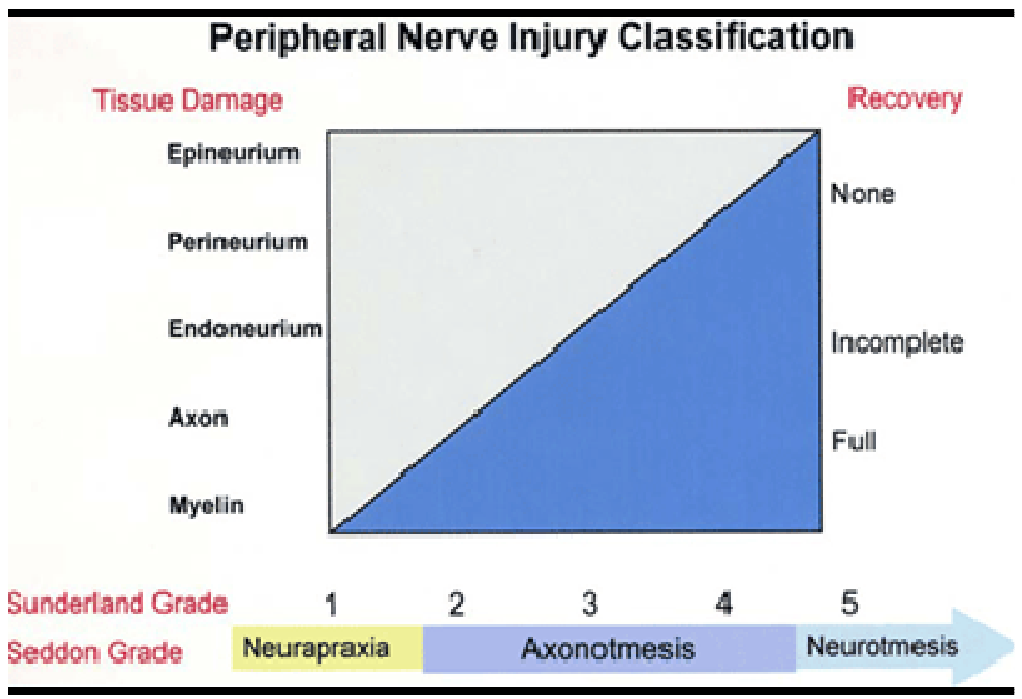

Fonte: www.medscape.com

Figura: Demonstrando a relação entre as duas classificações de lesões nervosas.

\subsection{Alterações histológicas após as lesões dos nervos periféricos}

Após uma lesão nervosa, ocorre um processo degenerativo no segmento distal que é chamado degeneração Walleriana ou centrífuga e no segmento proximal, conhecido como degeneração axônica ou centrípeta. A degeneração Walleriana é um processo de degradação de todas as estruturas do axônio distal à lesão, que perde sua continuidade com o corpo celular do neurônio. A degeneração axônica ocorre em alguns milímetros ou centímetros proximalmente à lesão e sua extensão varia de acordo com a intensidade do trauma. Nos processos de degeneração Walleriana e axônica há fagocitose das estruturas degradadas por macrófagos e células de Schwann, que deixam o tubo endoneural vazio e preparado para receber o axoplasma produzido pelo corpo celular durante o processo de regeneração nervosa.

A desmielinização segmentar ocorre geralmente quando há lesão de um segmento focal do nervo de forma que os segmentos proximais e distais permanecem intactos. Há lesão local da mielina com destruição de um ou mais internodos resultando em uma diminuição da velocidade da condução nervosa por prejuízo da função isolante e podendo acarretar alterações da função nervosa por condução as assincrônica no segmento, tais como alterações sensoriais, parestesias e alterações na velocidade das respostas 
reflexas. Perdida a mielina ocorre divisão das células de Schwann e inicia-se a remielinização, sendo a condução restabelecida em poucas semanas (MURRAY, 2005).

A degeneração Walleriana é um processo que pode ocorrer tanto nos esmagamentos como nas secções resultantes dos traumas em nervos periféricos. Na região proximal á lesão ocorre degeneração do axônio até o nódulo de Ranvier mais próximo, que, em situações extremas, acarreta a morte celular por apoptose, com diferentes mecanismos relacionados ás respostas induzidas por fatores neurotróficos (MACHADO, 1998; MARTINS, 2005). Uma importante reação enzimática e resposta imunológica com rápida ativação das células de Schwann ocorrem ao final do segmento proximal, por meio de um processo de divisão mitótica na tentativa de repor o tecido lesado (LACANNA, 2008).

No corpo celular ocorrem alterações do metabolismo e reorganização estrutural (MARTINS, 2005). Estas respostas provavelmente são iniciadas a partir do transporte retrógrado de sinais da lesão local, incluindo fatores de crescimento neurotróficos ciliares, produzidos pelas células de Schwann. Intensa cromatólise com aumento de proteínas citoplasmáticas, ingurgitamento celular, deslocamento do núcleo celular para periferia e dispersão dos ribossomos com degeneração da substancia de Nissl são observadas. Ocorre ainda incremento do metabolismo celular visando ao aumento na expressão de genes que estão relacionados á síntese de proteínas como a actina e tubulina e a regeneração do citoesqueleto do axônio (MARTINS, 2005; MURRAY, 2005).

A região distal a lesão é o local onde ocorrem as primeiras modificações, com o aumento da atividade de algumas proteinases e lipases culminando em desintegração do axônio e mielina que progride distalmente (MURRAY, 2005). Pode ocorrer degeneração Walleriana também nesta região, sendo este processo mediado pelas células de Schwann com expressão de genes e receptores na membrana (MARTINS, 2005).

No local da lesão há formação do cone de crescimento e reestruturação da matriz extracelular (MARTINS, 2005). As células de Schwann entram numa fase proliferativa onde há diferenciação e up-regulation da 
expressão de moléculas adesivas e neurotrofinas, importantes para a fase de regeneração (MURRAY, 2005).

Nos órgãos alvo pode ocorrer atrofia em um período variável de semanas a meses após a lesão dependendo do grau de reinervação. A denervação prolongada leva a degeneração irreversível das bainhas dos nervos intramusculares (MARTINS, 2005; MURRAY, 2005).

As células de Schwann fornecem substratos que permitem 0 apoio e o crescimento dos axônios em regeneração, desempenhando importantes papéis nas lesões dos nervos periféricos. Além disso, apresentam capacidade fagocítica e capacidade de secretar fatores tróficos que são captados pelo axônio e transportados ao corpo celular, desencadeando ou incrementando o processo de regeneração de fibras nervosas periféricas (MACHADO, 1998).

\section{$\underline{2.5}$ Regeneração Nervosa}

A recuperação nervosa periférica depende de fatores como o tipo, grau e extensão da lesão, técnica cirúrgica aplicada, distância da lesão ao corpo celular e a tensão aplicada ao reparo cirúrgico (VITERBO; FALEIROS, 2002).

Os nervos periféricos podem se recuperar de três maneiras, pela remielinização, pelo brotamento axonal e pela recuperação cirúrgica nervosa (RAMÓN and CAJAL, 1928).

$\mathrm{Na}$ remielinização ocorre a recomposição da camada de mielina lesada através da desmielinização segmentar. Esta é a forma mais rápida de recuperação, ocorrendo entre 2 e 12 semanas após a lesão (RAMÓN and CAJAL, 1928).

Quando ocorre a interrupção da continuidade axonal, parcial ou total, ocorre a degeneração axonal distal á lesão, logo nos primeiros minutos. Nas lesões axonais parciais encontramos um fenômeno chamado brotamento axonal, onde axônios vizinhos intactos passam a inervar a área desnevada pela lesão. Este fenômeno demora de dois a seis meses para ocorrer (VITERBO; FALEIROS, 2002; RAMÓN and CAJAL, 1928; GIROLAM et al., 2000). 
Após uma lesão completa do nervo periférico há necessidade do reparo cirúrgico.

O processo de degeneração e consequente regeneração nervosa periférica estão diretamente ligados ao tipo, grau e extensão da lesão nervosa como exemplificado no quadro a seguir

Quadro 2: Correlação entre o tipo, grau e extensão da lesão nervosa e sua regeneração.

\begin{tabular}{|c|c|c|}
\hline $\begin{array}{l}\text { Classificação da } \\
\text { Lesão }\end{array}$ & Danos & Regeneração \\
\hline 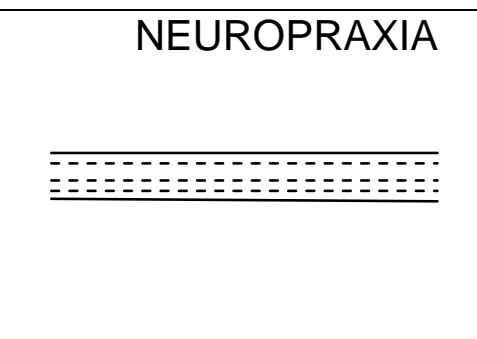 & $\begin{array}{l}\text { - Desmielinização } \\
\text { segmentar } \\
\text { - Bloqueio local de } \\
\text { condução }\end{array}$ & $\begin{array}{ll}\text { - } & \text { Remielinização } \\
& \text { espontânea } \\
\text { - } & 2-12 \text { semanas } \\
\text { - } & \text { Prognóstico } \\
& \text { favorável }\end{array}$ \\
\hline 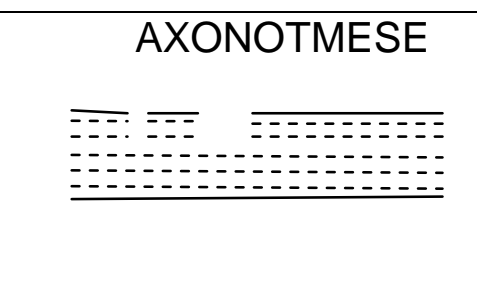 & $\begin{array}{l}\text { - Lesão axonal } \\
\text { - Degeneração } \\
\text { Walleriana }\end{array}$ & $\begin{array}{l}\text { - } \text { Brotamento axonal } \\
\text { - Regeneração lenta } \\
\text { - Recuperação } \\
\text { incompleta }\end{array}$ \\
\hline 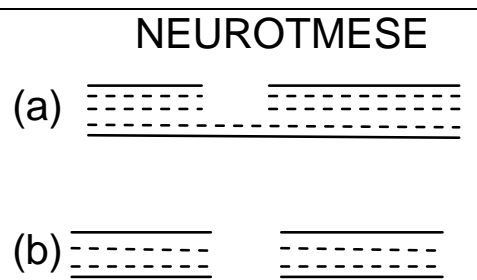 & $\begin{array}{l}\text { - Secção parcial ou } \\
\text { total do nervo }\end{array}$ & $\begin{array}{l}\text { - } \text { Recuperação } \\
\text { limitada } \\
\text { - } 18 \text { meses }\end{array}$ \\
\hline
\end{tabular}

\subsection{História e atualidade da cirurgia em nervos periféricos}

\subsection{1 - A evolução do tratamento das lesões dos nervos periféricos}

Até o século XIX sabia-se que, após a reparação de um nervo periférico, poder-se-ia obter a recuperação funcional das estruturas por ele inervadas, mas desconhecia-se o mecanismo pelo qual isto ocorria. Vários relatos de insucesso fizeram com que as reconstruções caíssem em descrédito. É surpreendente que a primeira publicação otimista, em relação a lesão de nervo periférico date de 1393, onde seu autor, Chauliac, relata suas observações sobre 
reparações de nervos periféricos e tendões que restabeleciam completamente a função. O conceito da reconstrução do nervo periférico, através de sua sutura, não foi aceito até 1850. Paget (1847) descreveu um paciente com 11 anos de idade, com lesão do nervo mediano, com recuperação total após um mês do reparo. Marie Jean Pierre Florens (1828) reportou o sucesso obtido com a transposição de nervos motores dos músculos flexores para extensores das asas de aves. Em 1850, Augustus Waller apresenta seu clássico trabalho sobre a degeneração nervosa após uma lesão. Trabalhando no laboratório de sua casa, descreveu a degeneração nervosa. O estudo de Waller nos nervos hipoglosso e glossofaríngeo de sapos demonstraram não apenas a degeneração do axônio distal, mas também o processo de regeneração nervosa, quando se mantém o cilindro-eixo intacto. Ele notou que a progressão da regeneração é mais rápida nos jovens e que a estimulação elétrica galvânica não altera a velocidade de regeneração. A importância de Augustus Waller pode ser expressa pela denominação de degeneração Walleriana dada ao conjunto de fenômenos que ocorrem no axônio distal após uma lesão.

Em seus trabalhos publicados em 1914 e 1928, Ramon y Cajal demonstram definitivamente que fibras nervosas viáveis, em um nervo periférico degenerado, originam-se e crescem a partir do coto proximal e não através de autorregeneração da porção distal degenerada. Seu tratado de histologia e patologia revoluciona os conceitos sobre nervos periféricos, de tal forma que autores modernos consideram-no responsável pelo início da era moderna nas pesquisas sobre regeneração nervosa. No século $X X$, nomes como Tinel, Seddon, Moberg, Sunderland e outros se associaram com os grandes avanços nos estudos das lesões, diagnóstico e tratamento em nervos periféricos. Os conflitos e as guerras, apesar dos malefícios que sempre trazem, proporcionaram avanços à custa do sofrimento humano. Durante guerra civil americana, Weir Mitchell relatou suas observações sobre lesões de nervos periféricos por armas de fogo. Seu artigo foi publicado em 1864 e inclui a primeira descrição sobre causalgia. Em 1872, o mesmo autor publica seu clássico trabalho Lesões de nervos periféricos e suas consequências. Durante a 1a guerra mundial, Tinel na França e Hoffman na Alemanha estudam a regeneração de nervos reparados. Em 1915, Tinel publica seu trabalho sobre 
regeneração de nervos, descrevendo a dor como sinal de irritação e mal prognóstico e o choque como sinal de reinervação. Seddon (1948) classifica os diversos tipos de lesão de nervos periféricos como neurapraxia, axoniotmese e neurotmese, como já anteriormente esclarecido. Seus conceitos de reparo de nervos periféricos e enxertos de nervo são obedecidos até hoje. Sunderland (1945), na Austrália, estudou com detalhes a anatomia topográfica interna dos nervos periféricos. Seu trabalho trouxe o suporte para a teoria moderna de reparo interfascicular.

\subsection{2 - Atualidades no tratamento das lesões dos nervos periféricos}

Desde os últimos 20 anos a neurorrafia termino lateral foi adicionada às opções cirúrgicas, embora esta técnica já tenha sido descrita no início do século passado. Neurorrafia término lateral foi, primeiramente, descrita como uma abordagem alternativa para o tratamento da paralisia facial, com número insuficiente de resultados funcionais (BERIS et al., 2006).

Após a lesão onde a porção de um nervo não está disponível para reparo, o coto distal pode ser suturado com a lateral de um nervo adjacente intacto como um método alternativo de reconstrução para restaurar a recuperação funcional de órgãos-alvo sensitivo e motor (VITERBO et al., 1992; ZHANG et al., 2002). Embora o reparo término lateral tenha sido bem sucedida em ambientes clínicos e experimentais, os resultados imprevisíveis e conflitantes fazem sua eficácia questionável (AL QATTAN, 2001; ROVAK; CEDERNA; KUZON, 2001; ZHANG; FISCHER, 2002).

No início de 1990, Lundborg et al. e Viterbo et al., demonstraram a sutura da extremidade distal de um nervo ferido ao lado de um nervo intacto sem danificar a função do nervo receptor. Desde então, muitos estudos têm mostrado bons resultados para a regeneração motora por coaptação terminal lateral (THAM e MORRISON, 1998; ZHANG; FISCHER, 1998; YAN et al., 2002; WALKER et al., 2004). Esta técnica cirúrgica pode ser aplicada clinicamente quando um segmento proximal do nervo esta intacta e não em casos como lesões por avulsão do plexo braquial ou defeitos dos longos de nervo (KOSTAKOGLU, 1999; MENNEN, 2003). 
A sutura epineural, técnica clássica eleita para a reparação nervosa, consiste em unir a porção epineural dos cabos nervosos proximais e distais com o menor número possível de suturas, diminuindo, assim, o tempo de intervenção e causando menor traumatismo ao tecido nervoso (URBANIAK, 1982; SAWAMURA; ABE, 1997).

O conceito básico da neurociência subjacente à possibilidade de reparação de nervos periféricos cortados é conhecido desde há muito tempo (TERZIS; SUN; THANOS,1997) se a continuidade é restabelecida entre os cotos proximal e distal por sutura término-terminal, os axônios decorrentes da rica brotação terminal imediatamente do ponto de transecção crescerá rapidamente ao longo das colunas da glia no coto distal e, eventualmente, reinervará territórios desnervado.

Com a finalidade de comparar a eficácia da utilização de veias invertidas com artérias invertidas para servirem de conduto para regeneração de nervos periféricos, como o Isquiático, o presente artigo verificou que após 10 semanas das cirurgias experimentais ambos os grupos demonstraram resultados morfométricos equivalentes (BARCELOS et al., 2003).

Mesmo se a perda de substância ocorre entre os dois cotos tornando impossível realizar o reparo término terminal direto do nervo a colocação de uma ponte entre os dois cotos permite regenerar os axônios para alcançar as colunas gliais do coto distal e, em seguida, seu território inervação original (BATTISTON, 2005; LUNDBORG, 2005).

Foram comparados os parâmetros obtidos na avaliação eletrofisiológica do potencial de ação do nervo e do potencial de ação motor antes e após 24 semanas do reparo no nervo ciático do rato previamente seccionado no lado direito com a utilização de sutura, denominado grupo $A$, adesivo de fibrina, o grupo B ou uma combinação das duas técnicas, grupo C. Não houve diferença entre os grupos na avaliação do potencial de ação do nervo, Quando consideradas a latência e a velocidade de condução mensurados na reoperação e a razão entre a velocidade de condução medida na reoperação e o mesmo parâmetro antes da secção do nervo, durante a mensuração do potencial de ação motor, os animais do grupo B apresentaram melhores resultados em relação aos do grupo A. Os animais do grupo C apresentaram 
melhores resultados em comparação com os do grupo A quando considerada a razão entre a velocidade de condução medida em 24 semanas do reparo e antes da secção do nervo durante a avaliação do potencial de ação motor. Concluiu-se que os animais em que o reparo dos nervos foi realizado com o adesivo de fibrina apresentaram melhores resultados em comparação com a sutura quando considerados os parâmetros obtidos na mensuração do potencial de ação motor (MARTINS et al., 2004).

Em oito ratos, o nervo ciático foram seccionados e aproximados usando dois fios absorvíveis 10,0 e fundidos por meio de CO2, solda a laser miliwatt (100 mW, tempo de exposição por um segundo pulso, tamanho do ponto 320 um), com a adição de um solda de proteínas (albumina bovina) para reforçar o local de reparo. O grupo controle consistiu de oito ratos em que os nervos foram aproximado com duas suturas com fio 10.0, absorvíveis e ,posteriormente, colados utilizando um selante de fibrina (Tissucol), e oito ratos em que os nervos foram reparados com suturas microcirúrgicas convencionais. Em estudos histológicos, todos os nervos revelaram vários graus de regeneração axonal, com fibras nervosas mielinizadas nos segmentos distais. Houve pequenas diferenças em favor do grupo tratado com laser de reparação, em termos de cicatrização no local do reparo. Em todos os grupos, o número de axônios distais ao local de reparo foi maior em comparação com os proximais, mas o diâmetro do axônio foi significativamente menor do que nos nervos de controle. Verificouse que o reparo do nervo tratado com laser é pelo menos igual (MENOVSKY; BEEK, 2001).

Comparando-se, em estudo experimental, a eficiência de adesivo de fibrina com a micro sutura realizada com fio de nylon em microneurorrafia em tíbia de 28 coelhos adultos, concluem que, apesar de haver uma melhora na técnica de reparação, essa técnica livre de sutura não supõe uma alternativa superior às suturas não absorvíveis na reparação nervosa primária (MOY; PEIMER; KONIUCH, 1988).

Não foi observada nenhuma ruptura secundária nos nervos coaptados pela técnica adesiva, sugerindo que a força de tensão desenvolvida pelo gel de fibrina foi suficiente nos estudos experimentais realizados (BECKER; GUEUNING; GRAFF, 1984). 
Realizou-se um estudo experimental para comparar a regeneração de nervos reparados com adesivo de fibrina biológico e aqueles suturados com nylon. Os experimentos foram realizados em nervos peroneais de ratos, e os resultados mostraram que os nervos em que se utilizou adesivo de fibrina exibiam melhor e mais rápida reinervação do que aqueles reparados por sutura, sendo indicada sua aplicação na prática clínica (FALDINI et al., 1984).

Em um estudo semelhante avaliou-se a utilização da cola de fibrina na anastomose nervosa, e velocidade de condução do estudo obtido por eletrodos de superfície. No modelo experimental, foram avaliadas as diferenças de velocidade de condução nervosa no pré-operatório e períodos pós-operatórios, para o nervo facial esquerdo de 12 coelhos. No nervo facial o valor normal da velocidade de condução média foi de 36,53 m por segundo. No pós-operatório, a velocidade de condução média foi aproximadamente $81 \%$ do valor médio normal. Uma correlação significativa não foi observada entre a velocidade de condução pós-operatório e o número de axônios regenerados. A cola de fibrina pode ser utilizada para anastomose nervosa nesse modelo animal e nesse tipo morfológico de nervo (SANDRINI; PEREIRA JUNIOR; GAY-ESCODA, 2007).

Os métodos atuais de reparação de nervos periféricos seccionados consistem em se juntar cotos diretamente ou preencher as lacunas de grande porte com enxertos nervosos autólogos. Em ambos os casos a superfície de terminações nervosas no coto são, normalmente, cortadas perpendicularmente ao eixo longitudinal do nervo. O resultado dessas operações, no entanto, ainda não é satisfatório. Neste estudo, o autor realizou cortes nas estruturas nervosas em 90 ou 30 Graus, a regeneração funcional foi avaliada pela análise de "walking track", durante 12 semanas de acompanhamento. Depois o peso muscular foi medido e os estudos histológicos realizados. Esta última categoria incluiu a contagem das fibras nervosas e células de Schwann, bem como a visualização de formação de cicatriz e fibrose epineural. Nervos cortados obliquamente apresentaram melhor recuperação funcional do que transecções perpendiculares. Números de fibras nervosas em crescimento no coto distal do nervo bem como o número de células de Schwann foram significativamente maiores na secção oblíqua que nos nervos perpendicularmente operados. Além disso, os axônios em crescimento foram organizados com mais regularidade 
após o tratamento na secção oblíqua. Estes dados indicam que a adesão ou a enxertia, dos cotos em ângulo agudo é um método mais eficaz de reparo do nervo que o procedimento normal realizado no ângulo reto (KOTULSKA et al., 2006).

Em outro estudo investigou-se a hipótese de que a aplicação de um agente de redução de cicatriz no local do reparo do nervo permitiria uma melhor regeneração axonal. O nervo isquiático de ratos esquerdo foi seccionado e imediatamente reaproximado com quatro pontos na região epineural. Em cinco grupos de oito ratos, foi injetado fator de crescimento transformador-B3, a interleucina-10, ou soro fisiológico e em torno do local do reparo, tanto antes como depois da secção do nervo Outro grupo de oito animais agiu como o grupo falso-operado. Após 6 semanas, o resultado foi avaliado pelo registro do potencial de ação composto (PAC), medição dos níveis de colágeno utilizando Picosirius Red, e contando o número de axônios mielinizados proximal e distal para a reparação. Os PACs evocados por estimulação elétrica distal a reparação não foi significativamente diferente do que nos controles. As contagens de fibras mielinizadas foram sempre superiores distais ao local do reparo, mas não houve diferença significativa entre os diferentes grupos. Concluiu-se que a administração de uma dose baixa de IL-10 ao lado do nervo reparo de nervo ciático reduz a formação de cicatriz e permite uma melhor regeneração de axônios danificados (ATKINS et al., 2007).

Demonstrou-se que o Corglaes, um vidro, biodegradável biocompatível, quando usado sob a forma de tubo sólido, apoiou a regeneração do nervo facial divididos em ovinos. Os tubos foram totalmente biodegradáveis e não havia nenhuma evidência de uma resposta inflamatória no tecido 10 meses após a sua inserção (GILCHRIST; JEANS; HEALY, 2006).

Em um estudo semelhante ao anterior os autores utilizaram um envoltório de fibra de vidro. Material biodegradável e biocompatível. Doze ovinos foram utilizados em cada um dos três grupos, sendo um controle. O lado escolhido para a realização da neurotmese e reparo foi o nervo mediano do membro superior. A média e a variância das razões de cada uma das variáveis medidas nos três grupos de reparo foram semelhantes, sugerindo que a 
regeneração do nervo ocorreu em um nível semelhante em todos os grupos de reparação (GILCHRIST; JEANS; HEALY, 2006).

O sucesso da regeneração do nervo periférico ainda é limitado em condutos artificiais, especialmente sobre as lesões extensas (SUEMATSU, 1989). A maioria dos pesquisadores tem focado sobre condutas feitas de polímeros naturais tais como colágeno, fibronectina (BALDWIN; HADDAD, 2001), alginato (SUZUKI et al.,2000; HASHIMOTO et al., 2002), agarose (BORKENHAGEN et al., 1998; DILLON et al., 1998), e ácido hialurônico (WANG et al., 1998; MOHAMMAD et al., 2000). Tal como acontece com tecidos (como veia), essas são frequentemente incapazes de suportar toda extensão de lesões longas devido à possibilidade de um colapso, a formação de cicatrizes, e reabsorção precoce. Polímeros naturais também podem induzir respostas imunes indesejáveis com desvantagens adicionais, incluindo de lote para lote, a variação no isolamento em larga escala produzida. Para evitar esses problemas, biomateriais sintéticos estão sendo amplamente exploradas para a implantação neural.

Relatou-se pela primeira vez, a utilização de um tubo de silicone bioartificial, no qual o nervo isquiático de ratos foi inserido e preso por oito pontos de nylon, em um gap de 10 milímetros (LUNDBORG et al., 1996). Mais tarde relataram um enxerto semelhante com uma ponte de $15 \mathrm{~mm}$ feita de condutos de silicone contendo oito fibras de colágeno ou fibras PLA e copolímero ácido graxo.

Silicone tem sido veementemente útil para estudar a regeneração do nervo. Entretanto, o problema associado à compressão crônica do nervo foi confirmado com essas estruturas bioduráveis (DUCKER; HAYES, 1968; MERLE et al., 1989), que exigem uma reoperação posterior para remoção do tubo.

Sintéticos bioabsorvíveis possuem os principais benefícios de flexibilidade além de boas características químicas e mecânicas, falta de antigenicidade, facilidade de disponibilidade. Para promover a recuperação em longo prazo foram feitos materiais biodegradáveis, como um polilactina (PLA) ou poliglicólico (PGA) (WEBER; et al., 2000; EVANS et al., 2002), ou polifosfoésteres (PHB) (HAZARI et al., 1999) que têm atraído grande atenção do meio científico. 
Para investigar a eficácia na regeneração de nervo Isquiático com gap de $25 \mathrm{~mm}$, utilizaram-se vasos incluídos em tubos de silicone. Um tubo do material mencionado, contendo vaso sural, foi projetado em um modelo do rato e interpostos entre os cotos proximal e distal de um nervo lesado. Ao fim de 12 semanas, poucos axônios mielinizados foram vistos nas porções mais distais dos nervos regenerados, em 6 dos 10 ratos, não foi percebido transmissão de potencial de ação em nenhum deles. Todavia, em 24 semanas todos os ratos tinham desenvolvido tecido neural nos tubos, que evocou os potenciais de ação nos músculos. Os vasos no interior dos tubos demonstraram trazer benefícios, sendo potencialmente úteis para a reparação de nervos periféricos em humanos (KAKINOKI et al., 1997).

$\mathrm{Na}$ intenção de verificar a eficácia da utilização de tubos de polietileno na regeneração de nervos Isquiáticos, camundongos foram objeto de análise. Após realizar um gap de $4 \mathrm{~mm}$, um tubo de $6 \mathrm{~mm}$ de comprimento foi inserido entre os cotos distal e proximal do nervo isquiático. Sendo que em um grupo foi inserido apenas o tubo, outro com tubo e um preparo purificado de colágeno e, por fim, o terceiro com tubo de polietileno acrescido colágeno e fator de crescimento neural. Os três grupos continham quatro animais cada. Após 6 semanas, os animais foram sacrificados e os nervos avaliados, os dados revelaram que no grupo onde houve 0 incremento do fator de crescimento ocorreu maior numero de células marcadas com fator identificador denominado Horseradish Perosidase (HRP), que segundo o artigo, representa maior grau de regeneração axonal, quando comparado aos outros grupos examinados (SILVA, 1989).

Lesão do nervo periférico é rotineiramente reparada por uso de enxerto nervoso autógeno, em detrimento dos nervos doadores saudáveis. São muitas as estratégias alternativas para realizar reparo, como uso de esqueletos tubulares para guiar a regeneração dos nervos danificados, mas apesar dos progressos realizados na melhoria dos materiais estruturais para os tubos, a recuperação funcional permanece incompleta. Por esta razão desenvolveu-se um implante biossintético, constituído de um hidrogel transparente com matriz colágena. Este estudo suporta a utilização destes tubos como uma alternativa 
viável para transplante autólogo na reparação de lesões do nervo com formação de grandes lacunas (TANSEY et al., 2011).

A utilização de fatores de crescimento associada a tubulização foram utilizadas com a finalidade de recuperar nervo isquiático de ratos transeccionados experimentalmente. $\mathrm{O}$ enxerto foi preparado a partir do omento maior, rico em tecido adiposo. Notou-se recuperação funcional significativa nos animais submetidos a esta técnica (CASTAÑEDA; KINNE, 2002).

O emprego do tecido adiposo tem se mostrado bastante promissor na regeneração de nervos periféricos, por varias razões, primeiro porque estar presente no feixe vásculo-nervoso, na superfície mais externa da túnica adventícia, assim, em contato intima com o epineuro dos mesmos. E segundo lugar, o tecido adiposo pode ser facilmente encontrado e extraído, sem causar quaisquer prejuízos funcionais ou estéticos aos objetos da pesquisa ou mesmo para pacientes (D’ANDREA et al, 2008).

Com a intenção de verificar a eficácia na utilização de gordura autóloga, ROSA-JUNIOR (2010) realizou sua aplicação em veias invertidas e posteriormente, com expectativa de potencializar sua capacidade regenerativa, fez aplicação de LASER de baixa intensidade. Verificou por meio dos achados histológicos que o grupo submetido ao tratamento apresentou espessura de bainha de mielina semelhante ao grupo controle final.

Fracasso regenerativo é evidente em simples canais de orientação de silicone sobre uma lacuna crítica em comprimento a cima de $10 \mathrm{~mm}$ em um modelo de implantação do nervo isquiático do rato (DAHLIN; LUNDBORG, 2001). Esforços consideráveis para melhorar o ambiente de regeneração no interior do canal, incluindo a adição de fatores neurotróficos (SAHENK et al, 1996;. BOYD; GORDON, 2002), as moléculas de matriz extracelular (BALDWIN; KREWSON; SALTZMAN, 2001; DOWSING et al., 2000; LABRADOR; BUTI; NAVARRO, 1998; WELLS; KRAUS; BATTER, 1997) e células de Schwann (EVANS et al., 2002; HALDLOCK et al., 2000; ANSSELIN; FINK; DAVEY, 1997; BROWN et al., 1996; BRYAN; WANG; CHAKALIS-HALEY, 1996; FIELDS et al., 1989; BRYAN et al., 2003; TIMMER; ROBBEN; MULLER-OSTERMEYER, 2003) tenham sido aplicadas. Ainda assim, a falta de estrutura de orientação interior para reforçar a migração de células não neuronais através da abertura de lesão 
pode limitar a regeneração do nervo, especialmente sobre as lacunas de lesões longas.

Enxertos musculares aproveitam-se das semelhanças entre a membrana basal do músculo esquelético tubular e tubos endoneurais dos nervos em degeneração. Enxertos de músculo em veias foram reivindicados como os ensaios clínicos mais encorajadores para regeneração de nervos periféricos (BATTISTON et al., 2000). No entanto, ainda há alguma controvérsia quanto ao completo equilíbrio das proteínas musculares em desnaturação e a orientação correta dos tubos de retenção basal.

A reparação por meio da tubulização foi um método para definir as diversas funções das células e moléculas envolvidas na regeneração de nervo periférico. Esta abordagem envolve a superação de uma lacuna do nervo com uma prótese tubular. Desta forma, o local inicial da ferida e regeneração de tecidos posteriores são totalmente cerradas no interior do tubo e são passíveis de análise mais detalhada. Estudos prévios realizados em vários laboratórios têm mostrado que dentro de 7 dias de reparação de tubulização do nervo ciático de ratos, coto proximal e distal são contato por uma ponte de fibrina contendo várias células derivadas do sangue (eritrócitos leucócitos e macrófagos). Esses elementos formam uma armação primária para orientar a migração de fibroblastos, células de Schwann e eventualmente processo axonal (KLJAVIN; MADISON, 1991; SJOBERG; KANGE, 1989).

Em alternativa aos enxertos de nervo na reparação de lesões aos nervos periféricos, produziu-se um tubo de $12 \mathrm{~mm}$ de comprimento feito de 2hidroxietil metil-metacrilato poroso e estudou-se sua capacidade regenerativa para a reparação das lacunas de, aproximadamente $10 \mathrm{~mm}$, cirurgicamente criadas em nervos isquiáticos de ratos. Comparado in vivo à eficácia da capacidade regenerativa desses tubos artificiais, com padrão-ouro, o enxerto de nervo. A regeneração axonal dentro dos tubos foi observada pelas oito semanas, com parâmetros de resultados comparáveis aos enxertos. Esta conclusão foi reforçada pelos resultados eletrofisiológicos e histomorfométricos. Após 16 semanas os grupos que utilizaram os tubos tiveram uma resposta bimodal, com $60 \%$ deles apresentando uma resposta semelhante à auto enxertos e os outros $40 \%$ tiveram resultados significativamente menores em diversos parâmetros. A 
regeneração axonal em tubos artificiais foi semelhante aos com enxertos nas semanas 8 e 16, no entanto, uma distribuição bimodal de regeneração foi observada nos tubos na 16ª semana (BELKAS; MUNRO; SHOICHET, 2005).

São componentes essenciais de um enxerto de nervo, um conduto e uma matriz interna que possa atuar como um veículo para fornecer fatores de crescimento, citosinas e células transplantadas. Idealmente, os materiais de apoio para dos tubos devem ter características físicas e bioquímicas semelhantes às encontradas próximas ao nervo. Apesar de algumas tubulizações artificiais recentes serem promissores em relação à absorção, histocompatibilidade, permeabilidade, não imunogenicidade, e a adesão das células de Schwann, eles tem sido utilizados apenas para reparar falhas curtas em nervo periférico (HALDLOCK et al., 2000; EVANS et al., 2002).

Transplante de células de Schwann cultivadas em enxertos de nervo periférico tem demonstrado melhorar a regeneração nervosa em modelos experimentais onde há lesão do nervo periférico (LUNDBORG et al., 1997; HADLOCK et al., 2000; RODRIGUEZ et al., 2000; EVANS et al., 2002). No entanto, sua aplicação clínica ainda é controversa. Isso pode ser atribuído à dificuldade expansão, isolamento e purificação de células de Schwann in vitro, bem como a imunorreação halogênica de células de Schwann. 


\section{3-Material e Métodos}



Foram utilizados 45 ratos (Rattus norvegiccus) da linhagem Wistar, jovens, machos, com 60 dias de idade (Fig.5), pesando em média 250g, provenientes do Biotério Central da Faculdade de Odontologia de Bauru, Universidade de São Paulo (FOB - USP) - Campus de Bauru - SP. Em vista da morte de 2 animais do grupo GEEP-sg, e a soltura do ponto de sutura do tubo no coto distal e consequente ausência de regeneração do mesmo grupo em mais 2 animais, consideramos os grupos com 8 animais e não 12 como originalmente.

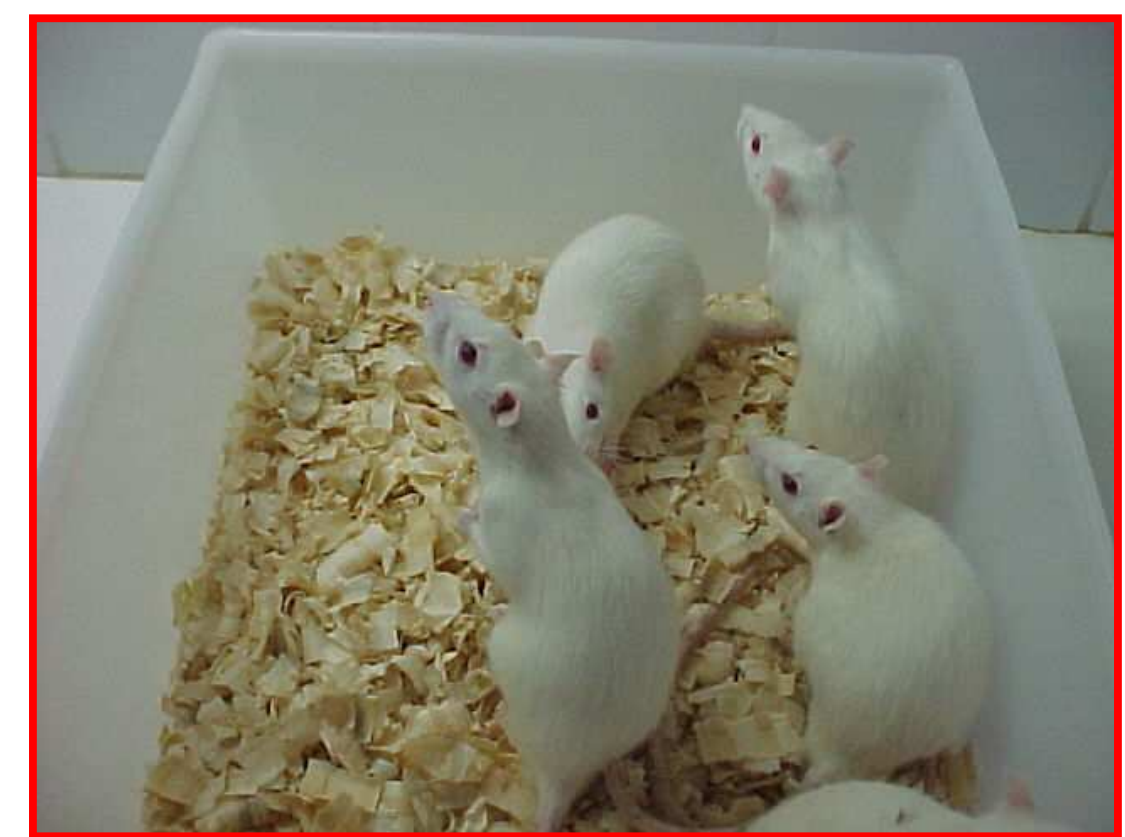

Fig.5: Imagem demonstrando correto acondicionamento dos animais em caixas apropriadas.

Os animais permaneceram em caixas apropriadas (fig.5) recebendo água e ração "ad libitum", sem restrições na movimentação, respeitando ciclos de 12 horas de luz, em temperatura média de $2^{\circ} \mathrm{C}$. O rato foi escolhido para este estudo devido ao fato que essa espécie, e especialmente 0 macho, é uma das mais frequentemente usadas na investigação de reparo de nervos periféricos

\section{$\underline{3.1 \text { - Distribuição dos animais em grupos: }}$}

Os 37 animais foram distribuídos em cinco grupos, sendo, três controles, e dois experimentais, assim constituídos: 
3.1.1 - Grupo Controle Inicial (GCl-60): Constituído de 7 animais. Nesse grupo, os animais foram sacrificados com sessenta dias de vida. Coletouse nervo isquiático, para se realizar a morfometria das fibras nervosas e obtenção dos seguintes dados: da área, do diâmetro das fibras e espessura da bainha de mielina. Através desse grupo, obtivemos dados morfométricos no início do experimento.

3.1.2 - Grupo Controle Final (GCF-150): Constituído de 7 animais. Nesse grupo, os animais foram sacrificados com cento e cinquenta dias após inicio do experimento. $O$ nervo isquiático foi coletado, para se realizar a morfometria das fibras nervosas e obtenção dos mesmos dados do grupo anterior. Através deste grupo, foram obtidos dados no final do experimento.

3.1.3 - Grupo Controle Desnervado (GCD-150): Constituído de 7 animais. Nesse grupo realizou-se uma incisão unilateral posterior de dois centímetros na coxa direita dos animais, divulsionando-se a musculatura subjacente, para exposição e secção do nervo isquiático com sessenta dias de vida e setenta e cinco dias após a primeira cirurgia. A extremidade proximal foi suturada no músculo adjacente, enquanto a extremidade distal foi suturada no tecido subcutâneo. Os animais foram sacrificados após os cento e cinquenta dias e, posteriormente, coletou-se a parte distal do nervo isquiático para que se realizar a morfometria das possíveis fibras nervosas presentes. Através desse grupo, obtivemos dados das fibras nervosas dos animais com quarenta e cinco dias de desnervação.

\subsection{4 - Grupo Experimental Enxerto de Polietileno sem} preenchimento (GEEPsp-150): Constituído de 8 animais, que foram sacrificados cento e cinquenta dias após o inicio do experimento. Realizou-se a exposição do nervo isquiático do lado direito e com o auxilio de um microscópio estereoscópico (DF Vasconcelos) seccionou-se e retirou-se um segmento de aproximadamente $1 \mathrm{~cm}$ de comprimento do nervo em questão. Após a secção, o nervo isquiático direito recebeu o enxerto de Polietileno Poroso sem preenchimento restabelecendo a comunicação entre o coto proximal e distal. 


\subsection{5 - Grupo Experimental Enxerto de Polietileno preenchido}

com gordura (GEEPcg-150): Constituído de 8 animais, sacrificados cento e cinquenta dias após o inicio do experimento. Nesse grupo, realizou-se a exposição do nervo isquiático do lado direito e com o auxilio de um microscópio estereoscópico (DF Vasconcelos) seccionou-se e retirou-se um segmento de aproximadamente $1 \mathrm{~cm}$ de comprimento do nervo em questão. Após a secção, o nervo isquiático direito recebeu o enxerto de tubo de polietileno poroso preenchido com gordura, restabelecendo a comunicação entre o coto proximal e distal. A gordura foi obtida junto à área de obtenção do enxerto.

\section{2 - Características Morfológicas dos tubos de Polietileno}

\section{Poroso:}

Os tubos de Polietileno Poroso foram confeccionados a partir de informações colhidas em outros artigos que lançaram mão do mesmo artificio. Todavia, no presente trabalho realizou alterações no modelo tradicional, como por exemplo a implantação dos poros e aumento do comprimento para $12 \mathrm{~mm}$ (Fig.6 e 7) .O tubo foi confeccionado pela empresa de materiais ENGIMPLAN, e os poros foram realizados á laser pelo Departamento de Física da Universidade de São Paulo de São Carlos, gentilmente coordenada pelo Professor Doutor Marcelo Andretta.

\section{Tubo de Polietileno Poroso 50 um}
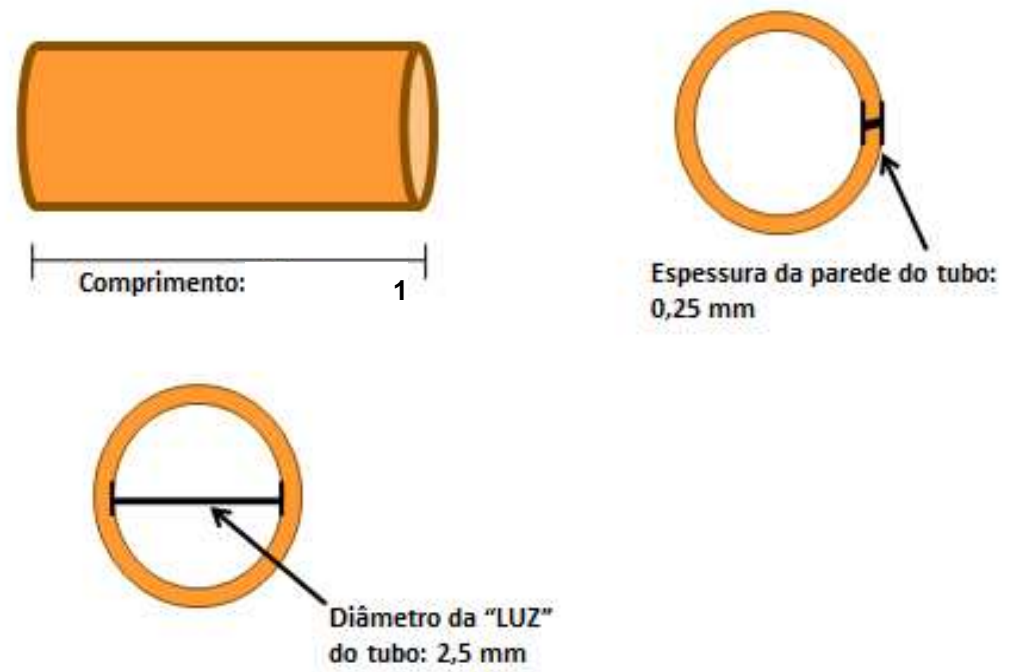

Fig.6: Demonstração esquemática do tubo de Polietileno Poroso. 


\section{Tubo de Polietileno Poroso 50 um}

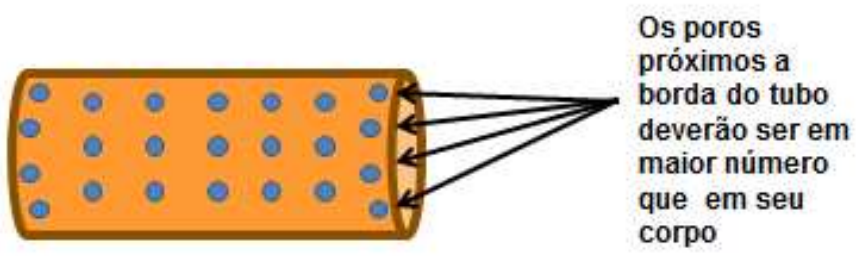

Os poros deverão ser em maior número corpo
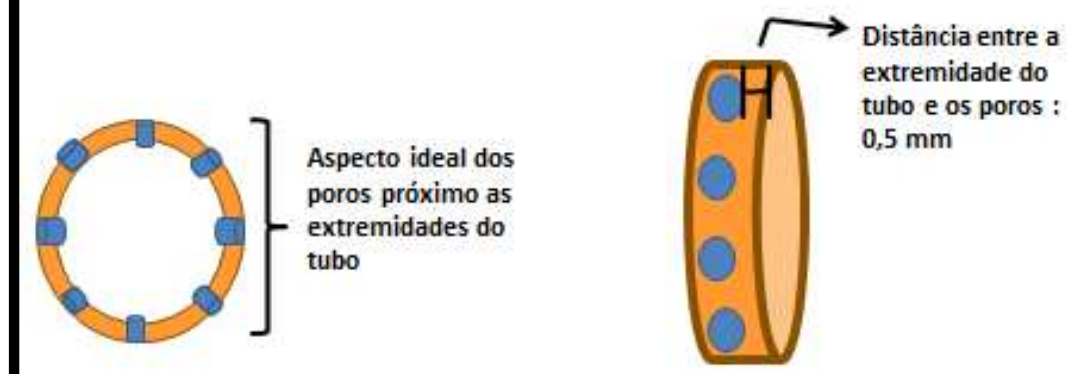

Fig.7: Demonstração esquemática do tubo de Polietileno Poroso.

\section{3 - Procedimentos Cirúrgicos e Coleta das Amostras:}

Todos os procedimentos cirúrgicos e de coletas, foram realizados por uma única pessoa, padronizando-os nos dois grupos experimentais, e nos três grupos controles. Pesaram-se os animais e os submeteram à anestesia geral através de injeção intramuscular de Cloridrato de Tiletamina, associado com Cloridrato de Zolazepam (50 mg / Kg) coxa esquerda (Fig.8). Serão adotadas técnicas assépticas em todos os procedimentos cirúrgicos.

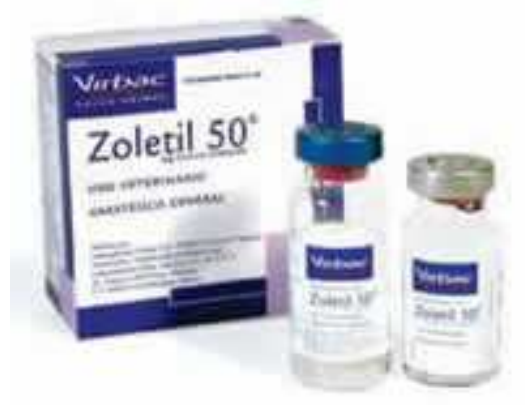

Fig.8: Exemplar do anestésico utilizado nos procedimentos cirúrgicos. 
Realizou-se a tricotomia da face dorsolateral do membro pélvico direito em todos os grupos (Figs: 9 e 10).

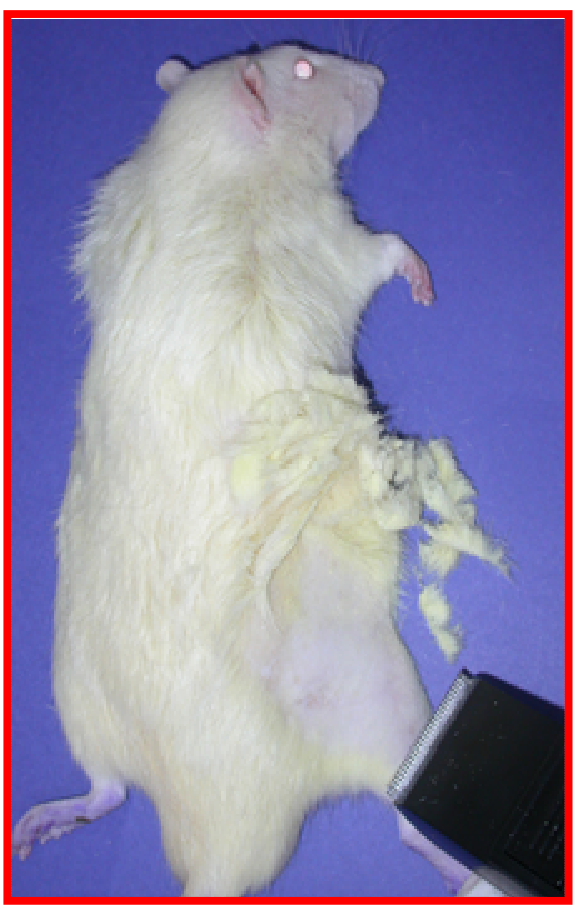

Fig.9: Realização de tricotomia na face lateral do membro inferior direito do rato.

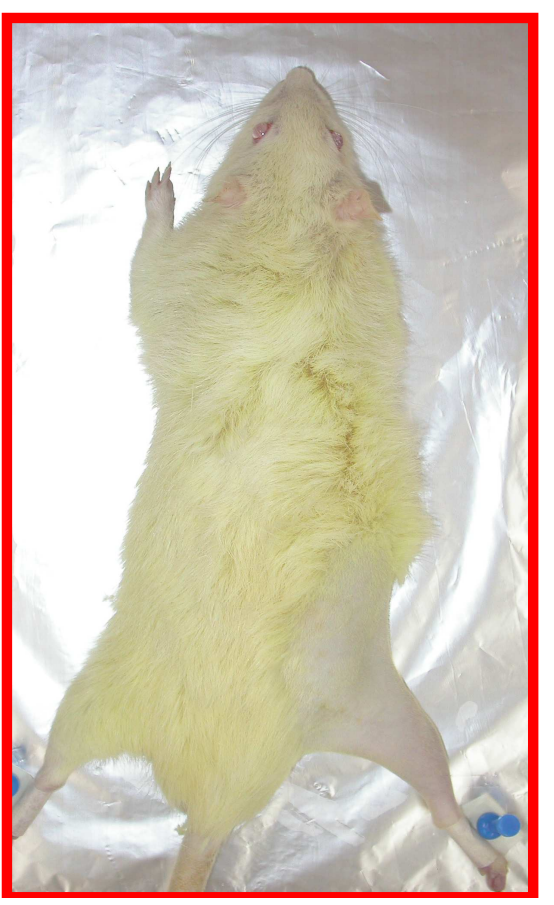

Fig.10: Animal com as patas fixadas na placa de cortiça com auxilio de fitas adesivas.

Nos grupos GCI-60, GCD-150 e GCF-150 os animais foram posicionados em decúbito ventral na placa de cortiça, fixadas as patas com fita adesiva, e posteriormente efetuou-se uma incisão longitudinal na face dorsolateral da coxa direita, com aproximadamente dois centímetros de comprimento. Rebateu-se a pele e a tela subcutânea e os músculos subjacentes para exposição e dissecação do nervo isquiático. Após a coleta de um segmento médio do nervo de, aproximadamente, $1,5 \mathrm{~cm}$ de comprimento dos grupos Inicial e Final (GCI-60 e GCF-150), e do segmento do coto distal do nervo ciático do Grupo Controle Desnervado (GCD-150), de aproximadamente um centímetro e meio, as amostras foram fixadas em Formol, Karnovsky e Glutaraldeído e, posteriormente, as incluímos em parafina, logo após destinamos as amostras de nervos para o processamento histológico. 
No grupo experimental (GEEPsg-150), os animais foram posicionados em decúbito ventral (Fig.11) numa placa de cortiça, fixados as patas com fita adesiva, e uma incisão longitudinal na face dorso lateral da coxa direita efetuouse com aproximadamente dois centímetros de comprimento, rebatemos a pele, a tela subcutânea e a divulsionamos os músculos adjacentes para exposição e dissecação do nervo isquiático (Fig.12). Após a remoção de um segmento medindo cerca de um centímetro, colocou-se o tubo de Polietileno Poroso (Fig.13), suturando seus cotos proximal e distal com fio de sutura mononylon 100 , não houve preenchimento, e para o grupo GEEPcg-150 houve preenchimento com gordura (Fig.14, 15, 16, 17 e 18).

Após a cirurgia, até os animais retornarem da anestesia, colocou-se em caixas aquecidas por luz incandescente a fim de evitar a hipotermia.

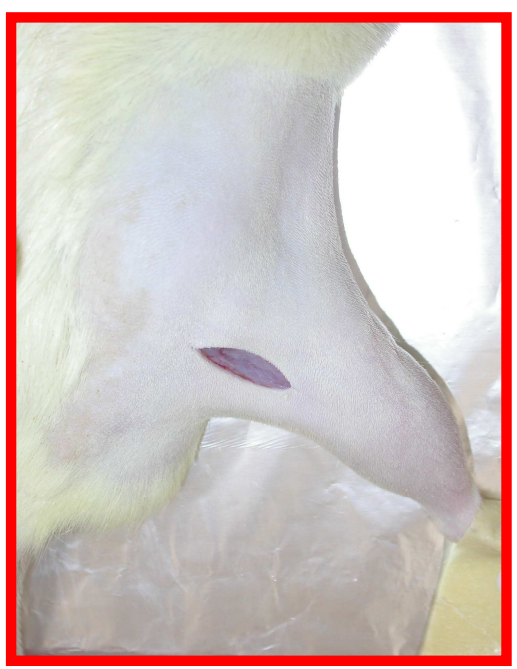

Fig.11: Incisão de $2 \mathrm{~cm}$ na face lateral da coxa direita do animal.

No período de 150 dias pós-operatório, os animais do grupo experimental (GEEPsg-150), submeteu-se à anestesia geral através de injeção intramuscular na região dorso lateral da coxa esquerda de Cloridrato de Tiletamina associado com Cloridrato de Zolazepam (50 mg / Kg), após a coleta dos referidos nervos e músculos, os animais formam sacrificados através de suplementação da dose do anestésico. 


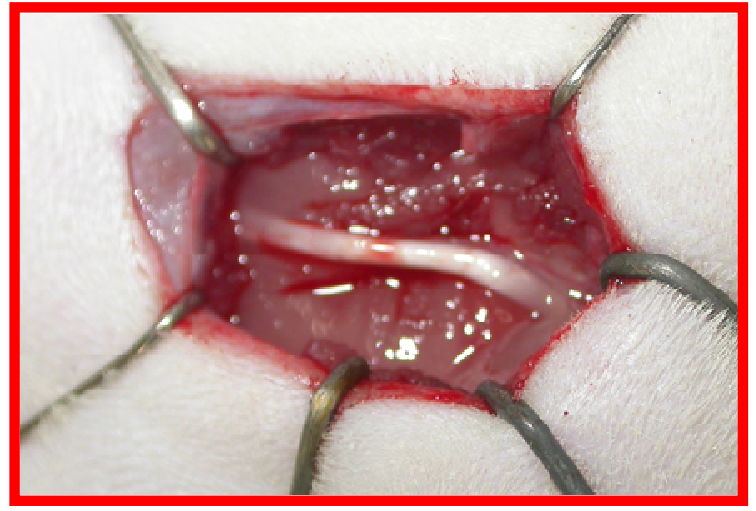

Fig.12: Após a incisão e divulsão dos tecidos subcutâneos e musculatura subjacente, notase exposição do nervo isquiático.

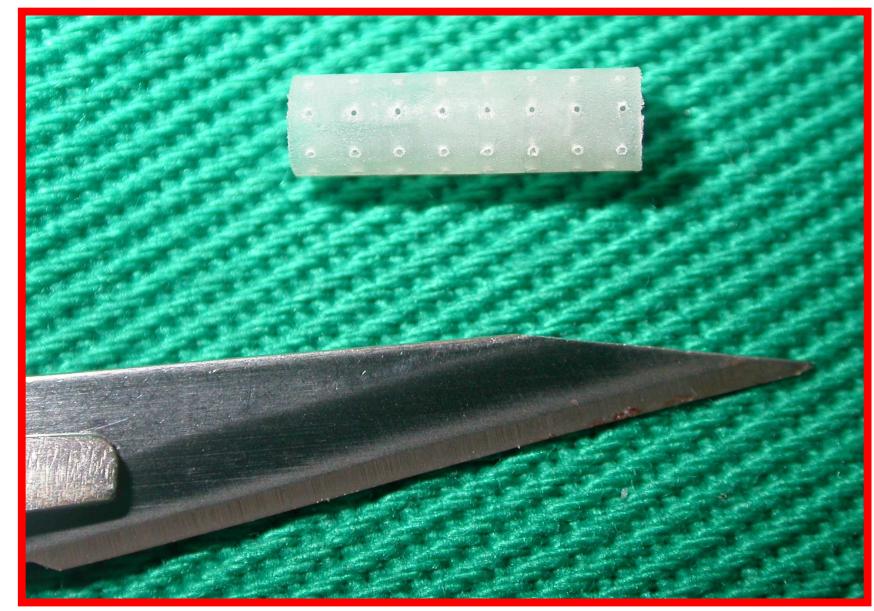

Fig. 13: Aspecto do tubo de polietileno poroso, podemos comparar seu tamanho com uma lâmina número 11.

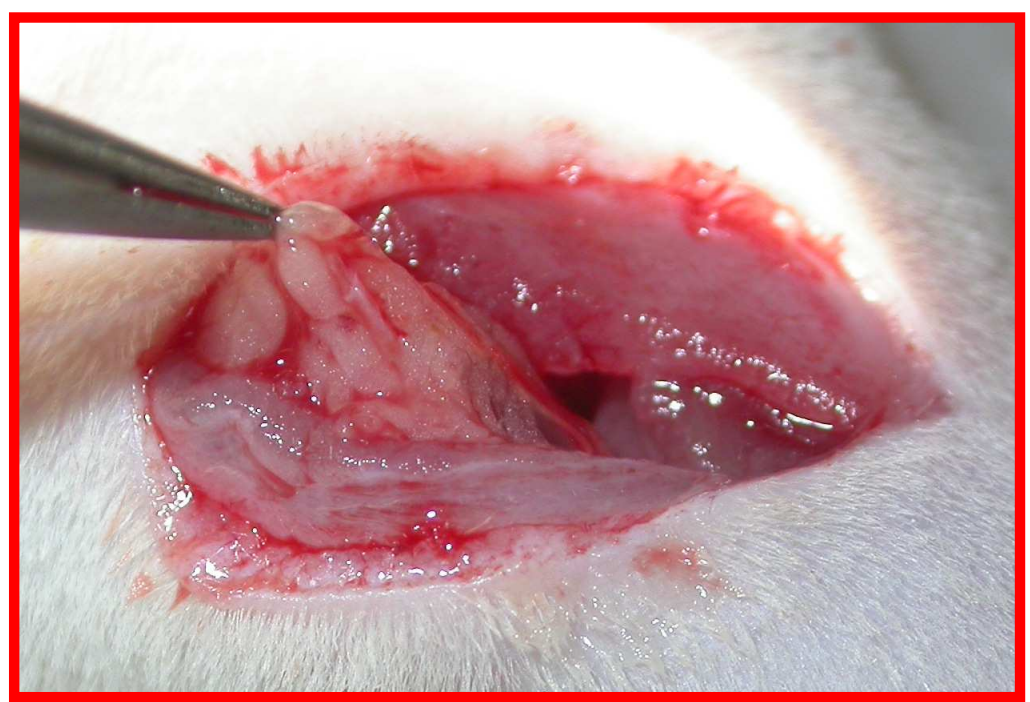

Fig.14: Demonstração da remoção da gordura in situ que, posteriormente, foi utilizada no grupo experimental com preenchimento. 


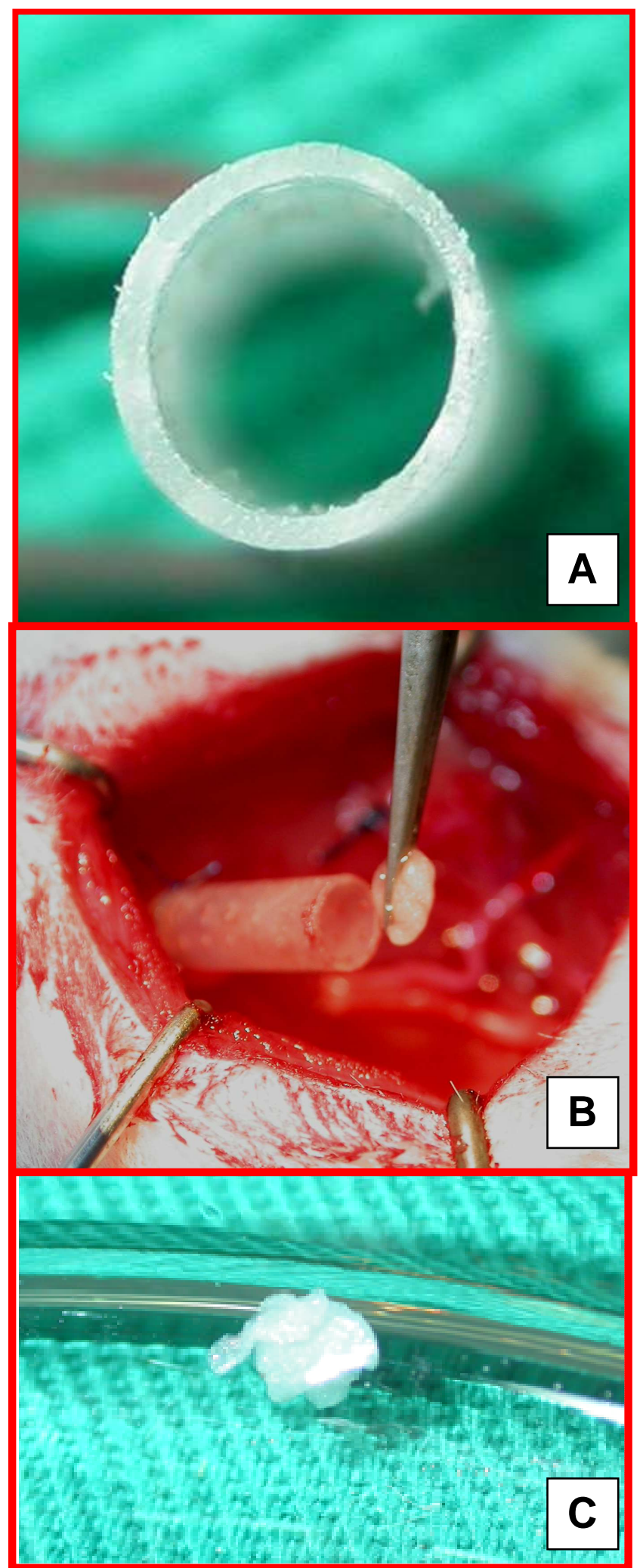

Fig.15: Em A - Vista aproximada do tubo de polietileno poroso, podemos notar a espessura de sua parede; Em B - Imagem revelando a inserção da gordura autógena no interior do tubo do grupo de enxerto experimental com preenchimento; Em C - Gordura inserida em recipiente com soro fisiológico $0,9 \%$. 


\section{\begin{tabular}{l|l}
3 - Material e Métodos & 63
\end{tabular}}

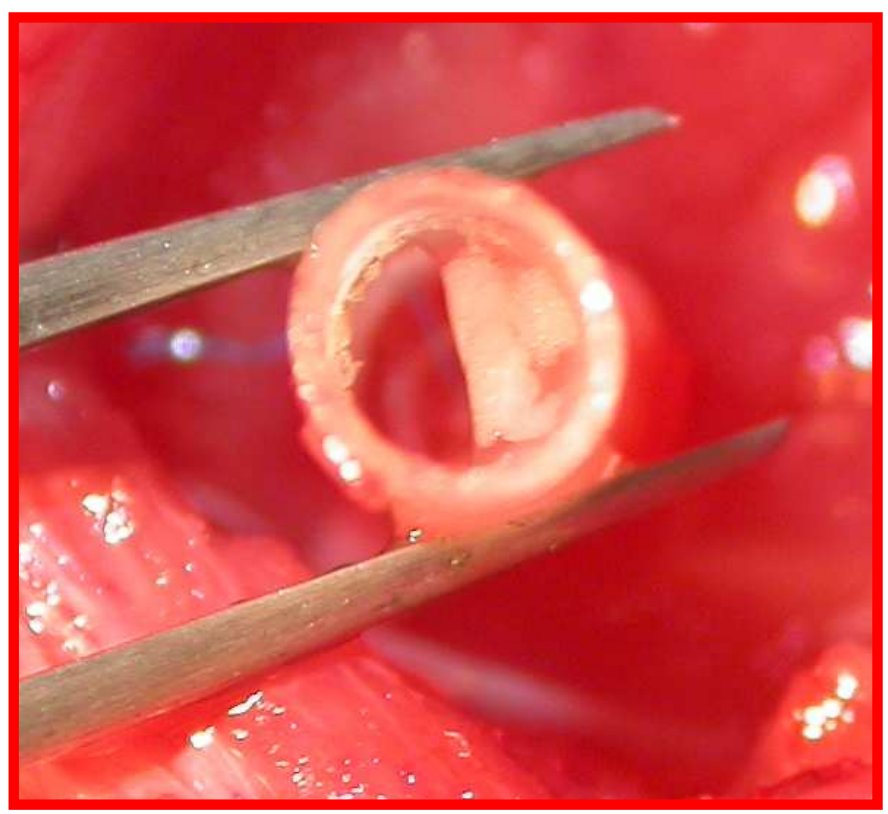

Fig.16: Verificamos por esta tomada a correta colocação do tecido adiposo, sem obliterar totalmente o lume do tubo de polietileno.

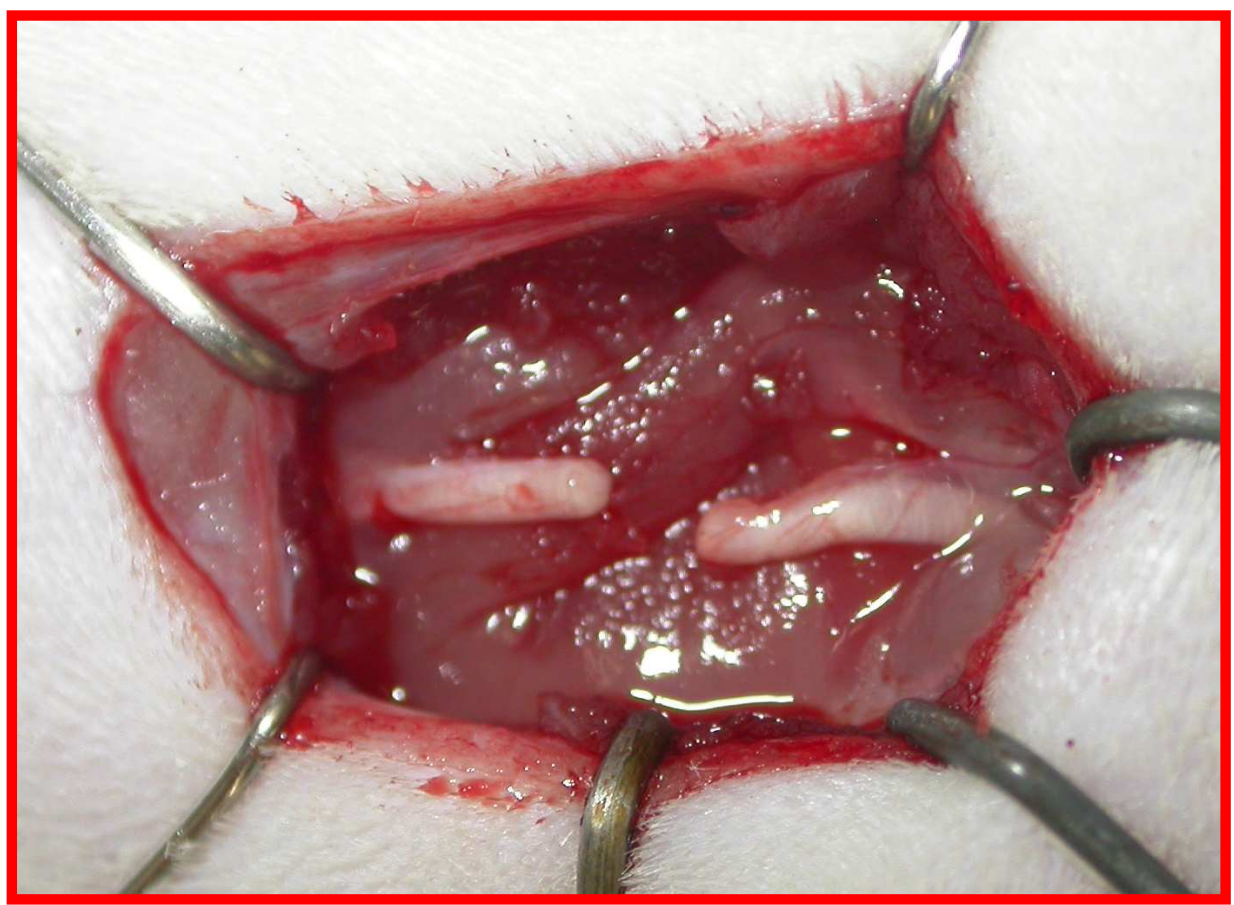

Fig.17: Nervo isquiático após a lesão cirurgicamente provocada. 


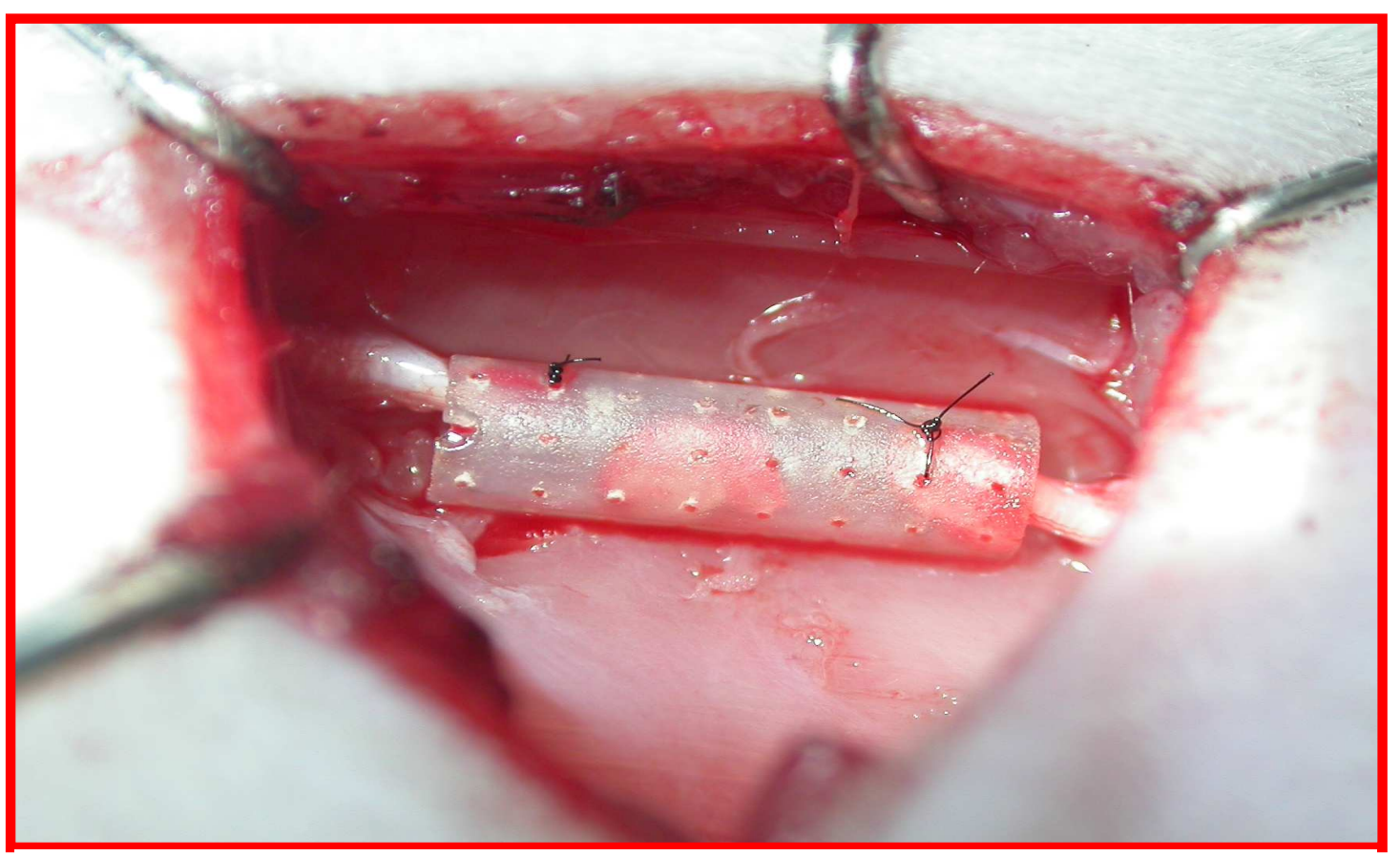

Fig.18: Tubo do grupo GEEP-CP, fixado em suas extremidades com fio mononylon 10.0. Note, por transparência a presença da gordura recostada na parede lateral do tubo.

\section{4 - Analise Funcional do nervo Isquiático:}

Antes dos animais serem sacrificados para a coleta do material, três deles, de cada grupo, foram selecionados aleatoriamente, para serem submetidos á avaliação funcional do nervo isquiático. Para tanto, os animais forma imobilizados, e a região plantar de suas patas posteriores foram pintadas com tinta de carimbo. No assoalho de uma canaleta de madeira, colocou-se uma faixa de papel para que os animais caminhassem e deixassem suas impressões no mesmo. Este procedimento foi repetido duas vezes por animal. As distancias entre as impressões dos membros posteriores foram avaliadas segundo a equação de Bain, Mackinon e Hunter (1989). Com base nos resultados de De Medinaceli, Fred e Wyat (1982). As impressões de difícil analises, pela má impressão foram descartadas, e as demais foram escaneadas e digitalizadas. Realizou-se as medições com auxílio do programa Image Pro-plus, e os dados obtidos foram submetidos ao tratamento estatístico obedecendo ao índice $\mathrm{P}<0,05$ para todas as amostras. 


\section{5 - Processamento Histológico dos Nervos (Isquiáticos):}

Para o tratamento histológico, as amostras de todos os Grupos, e dos nervos isquiáticos, passaram por um protocolo de inclusão em parafina, onde serão confeccionados os blocos, para posteriormente obter os cortes histológicos para coloração e avaliação morfométrica.

\section{6 - Processamento para análise morfométrica:}

Realizou-se a morfometria do nervo Isquiático, com mensuração de 220 fibras de cada animal de cada grupo, utilizando um micro computador com 0 software de captura e análise de imagem Image Pro-Plus 6.0, acoplado ao microscópio óptico Olympus BX-50. A morfometria dos nervos foi realizada para verificarmos a eficiência da regeneração nervosa nos diferentes grupos.

\section{7 - Forma de Análise dos Resultados:}

Os dados obtidos pelas diferentes técnicas foram confrontados e submetidos à análise estatística. 
66 |3-Material e Métodos 
4 - Resultados 



\section{1 - Observações Macroscópicas:}

Em todos os animais dos grupos experimentais notou-se uma paralisia da pata do lado onde o $\mathrm{n}$. isquiático foi seccionado, semelhante à chamada "Waiters tip hand", a mão de garçom (Fig.19), como nas lesões altas do plexo braquial (C5; C6).

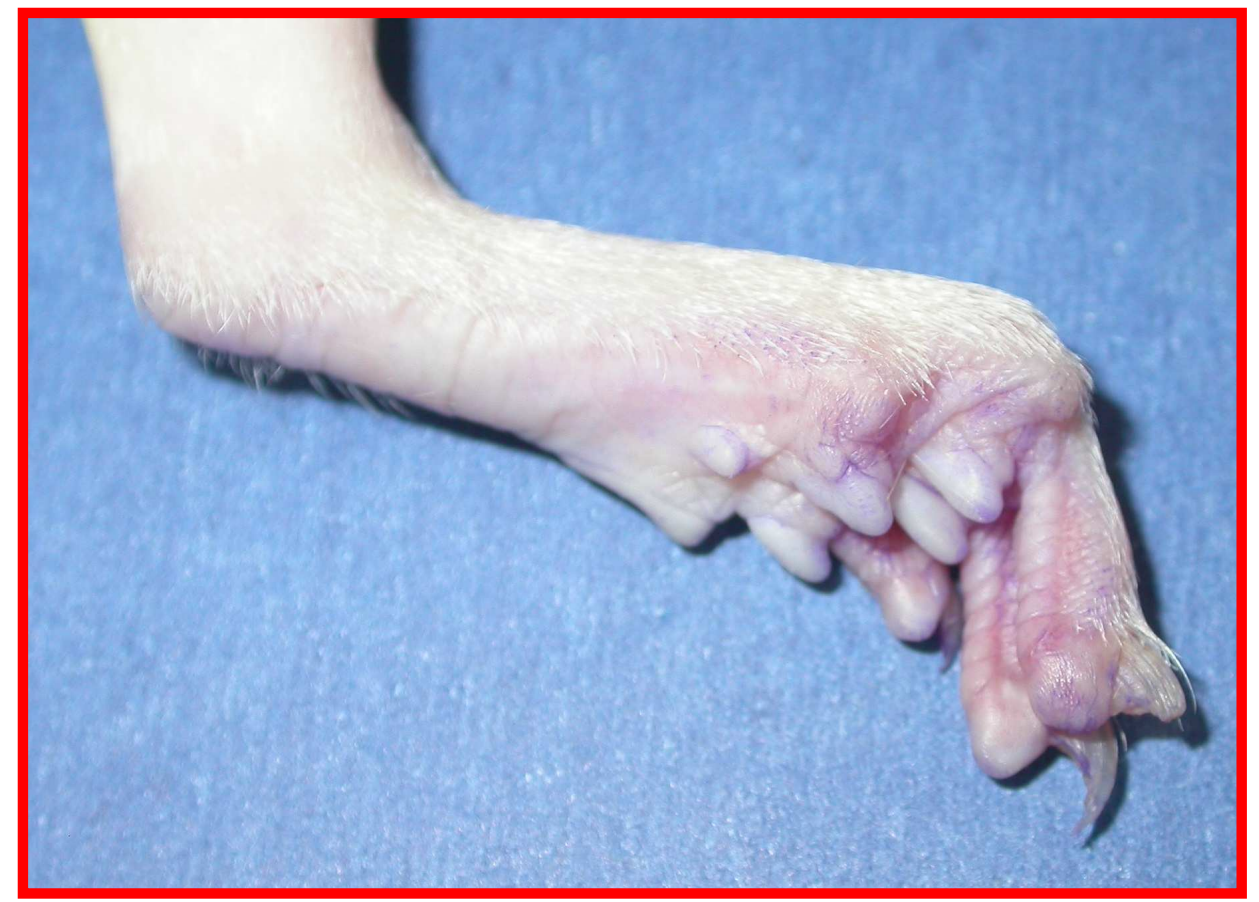

Fig.19: Nota-se paralisia da pata direita do animal do grupo GEEP-CP.

\section{2 - Procedimentos cirúrgicos:}

Durante os procedimentos cirúrgicos, as observações macroscópicas da dissecção do nervo isquiático para a realização da técnica de tubulização, foi levado em conta as possíveis variações anatômicas apresentadas na trifurcação do mesmo. Alguns animais apresentaram o nervo fibular comum já isolado desde a sua origem no plexo sacral.

Em alguns animais o Grupo Experimental foi observado uma fibrose próxima ao tecido adjacente à região anteriormente manipulada (Fig.20 e 21).

Não foi possível observar macroscopicamente alterações no comprimento do nervo isquiático nos grupos experimentais quando comparados 
com o controle, entretanto, nos músculos, essa diferença foi bastante evidente e visível macroscopicamente.

Em vista da utilização de material não reabsorvível, houve a necessidade de realizar cuidadosa remoção do tubo, este procedimento foi realizado com uma lâmina de bisturi com auxilio de um microscópio cirúrgico.

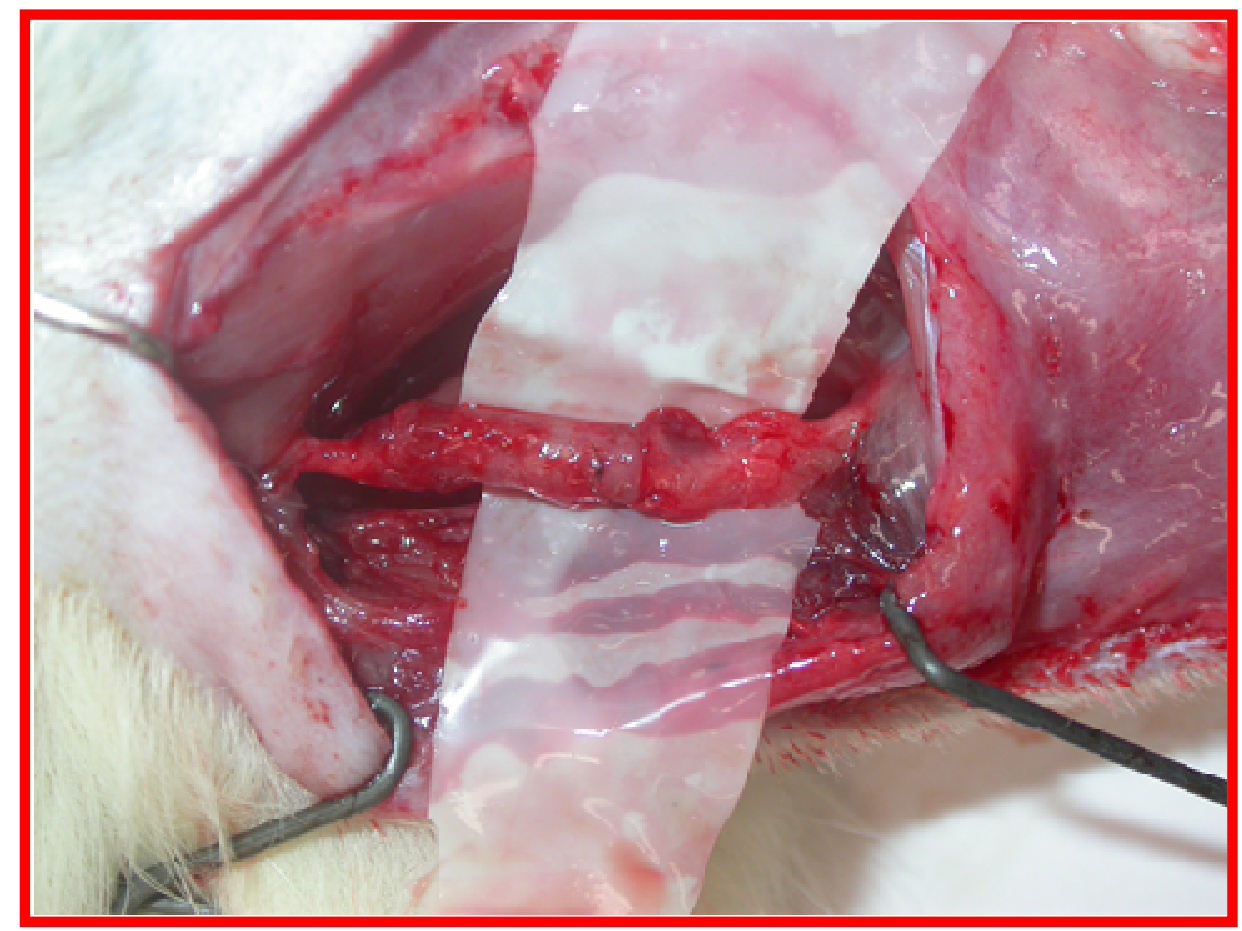

Fig.20: Incisão realizada na face lateral da coxa direita do animal do grupo experimental de enxerto com preenchimento. Nota-se densa formação de tecido conjuntivo circundando o tubo de polietileno poroso. Para melhor exposição da estrutura nervosa utilizamos fita de látex.

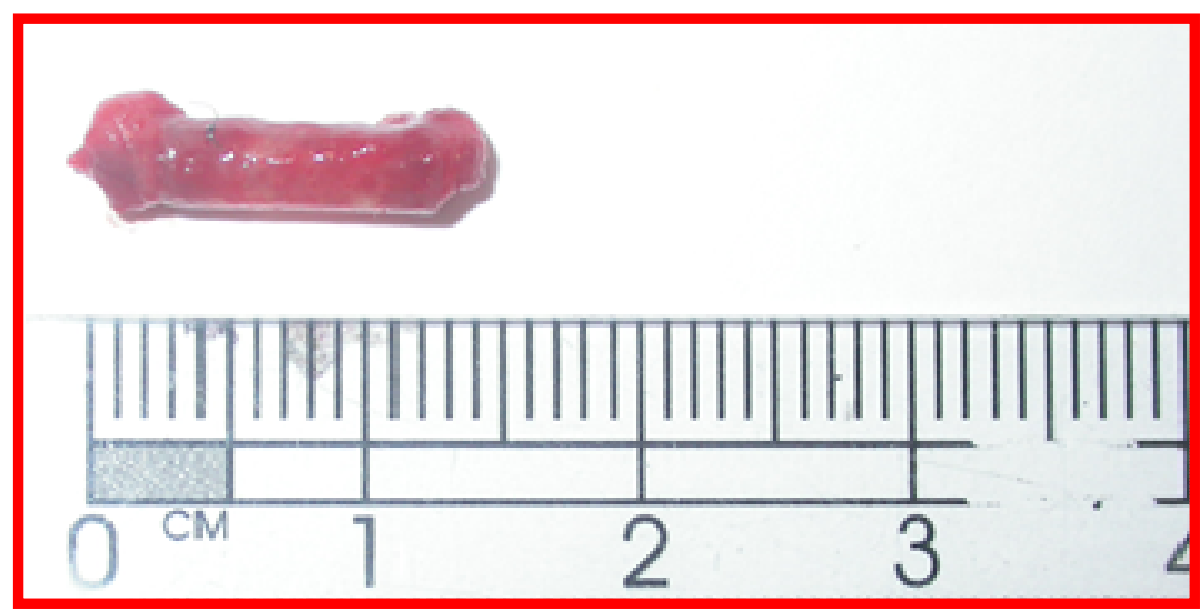

Fig.21: Após a remoção do tubo do sitio cirúrgico, observamos densa colonização por tecido conjuntivo. 
4- Resultados $\mid 71$

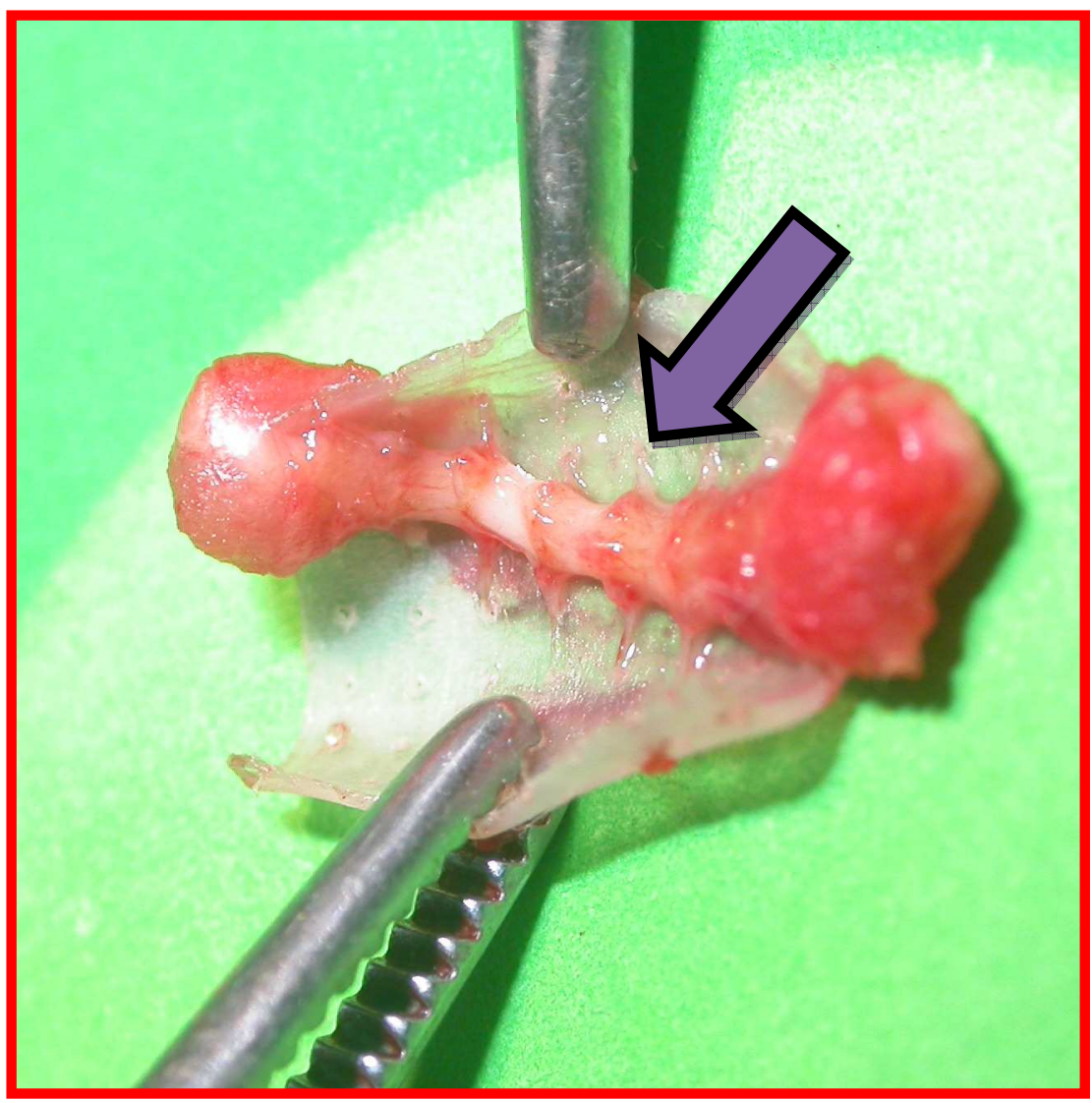

Fig.22: Animal do grupo experimental de enxerto com preenchimento com gordura. Observa-se evidente sinal macroscópico de regeneração nervosa (cabo de regeneração) como podemos notar na seta.

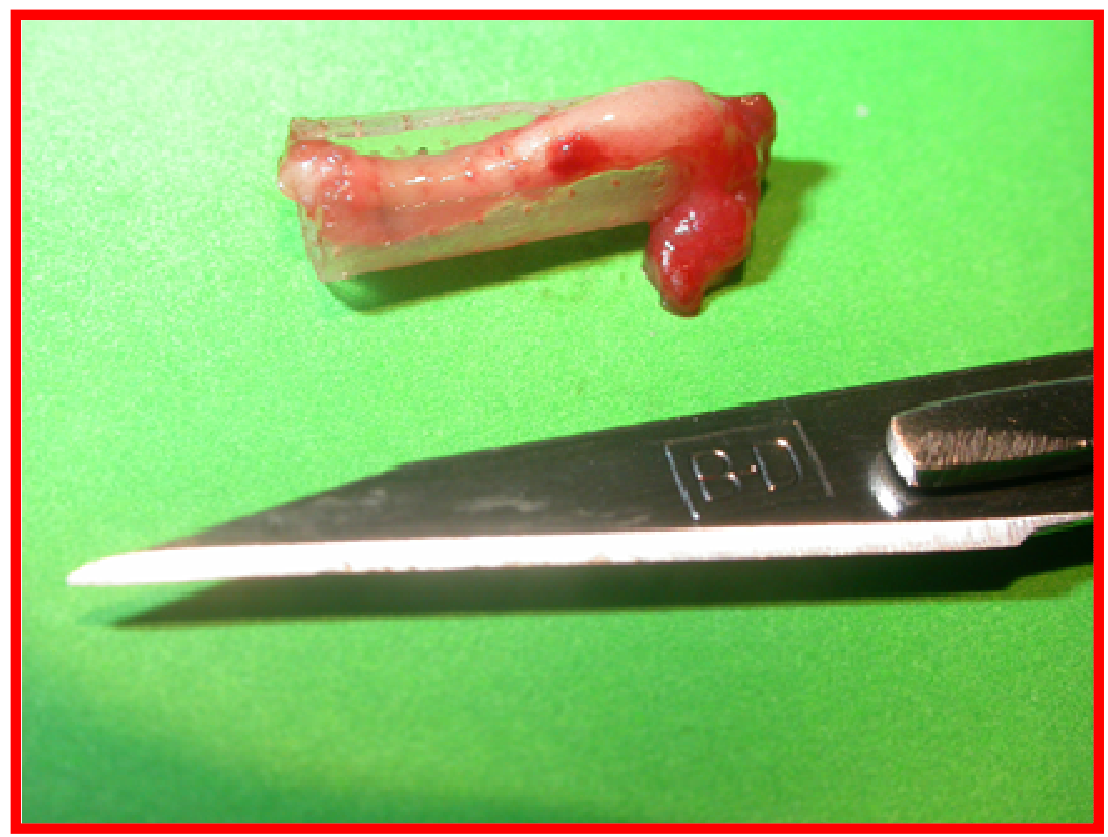

Fig.23: Animal do mesmo grupo experimental da foto anterior, contudo observa-se ausência de regeneração "em ampulheta". 
$\mathrm{Na}$ grande maioria dos grupos experimentais notou-se que após a remoção do nervo supostamente regenerado de dentro do tubo, apresentava a forma de "ampulheta" (Fig. 22).

\section{3-Observacões Histológicas:}

Em todos os animais dos grupos experimentais foi observado nos cortes histológicos dos nervos uma grande quantidade de tecido conjuntivo denso substituindo o tecido nervoso.

Nos dois grupos experimentais notamos irregularidades das fibras nervosas, entretanto mais acentuadamente no Grupo Experimental de Enxerto sem preenchimento. De modo geral, os cabos de regeneração mostraram-se constituídos por fibras nervosas mielínicas e amielínicas de diâmetros heterogêneos (Fig.25).

Nas laminas histológicas dos nervos impregnados com tetróxido de Ósmio observou-se que não houve uma boa fixação no centro do mesmo, provavelmente pela dificuldade de penetração do agente ou pelo tempo de permanência do material na solução (Fig.24).

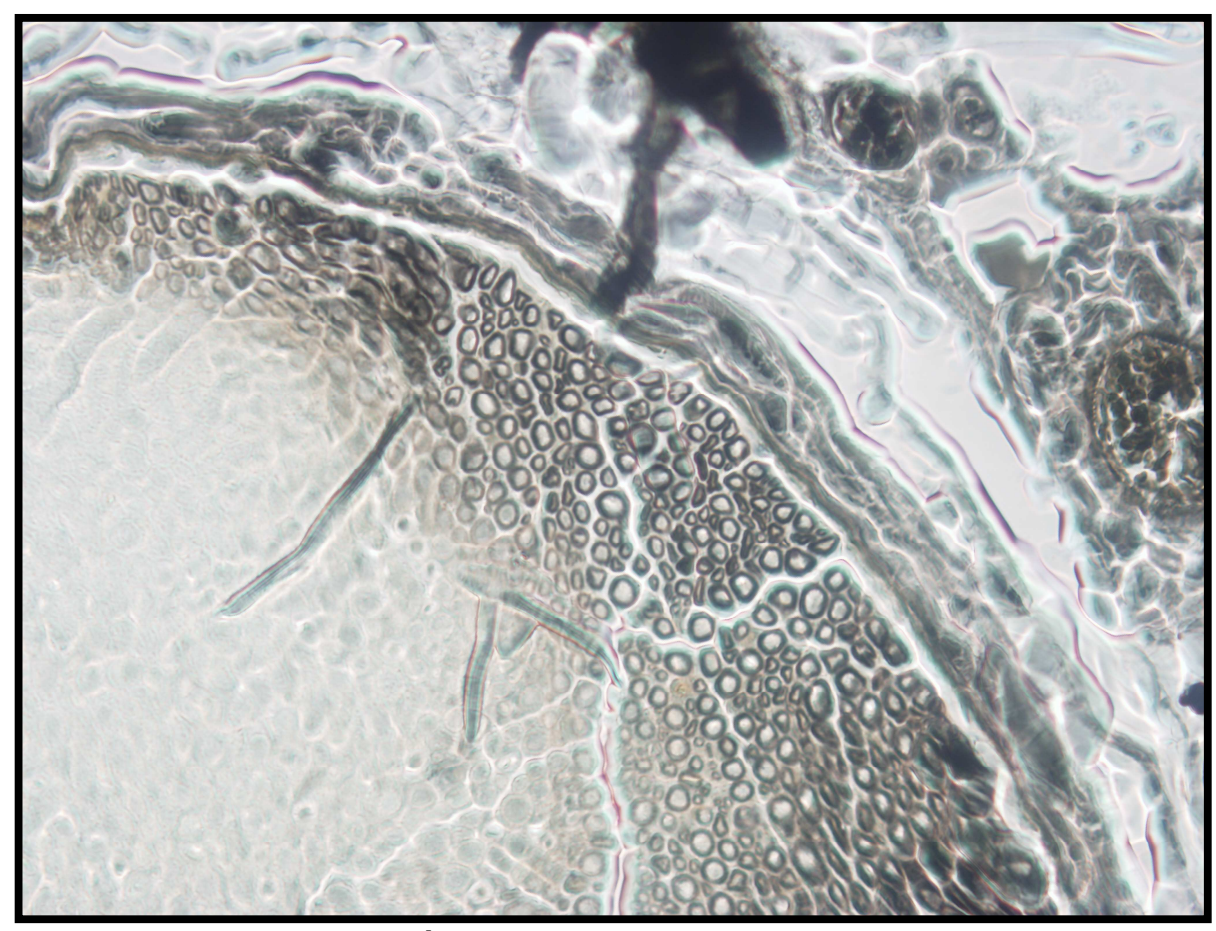

Fig.24: Imagem histológica em aumento de 400x demonstrando que não houve boa fixação com o tetróxido de Ósmio na porção central do nervo isquiático. 
4- Resultados $\mid 73$
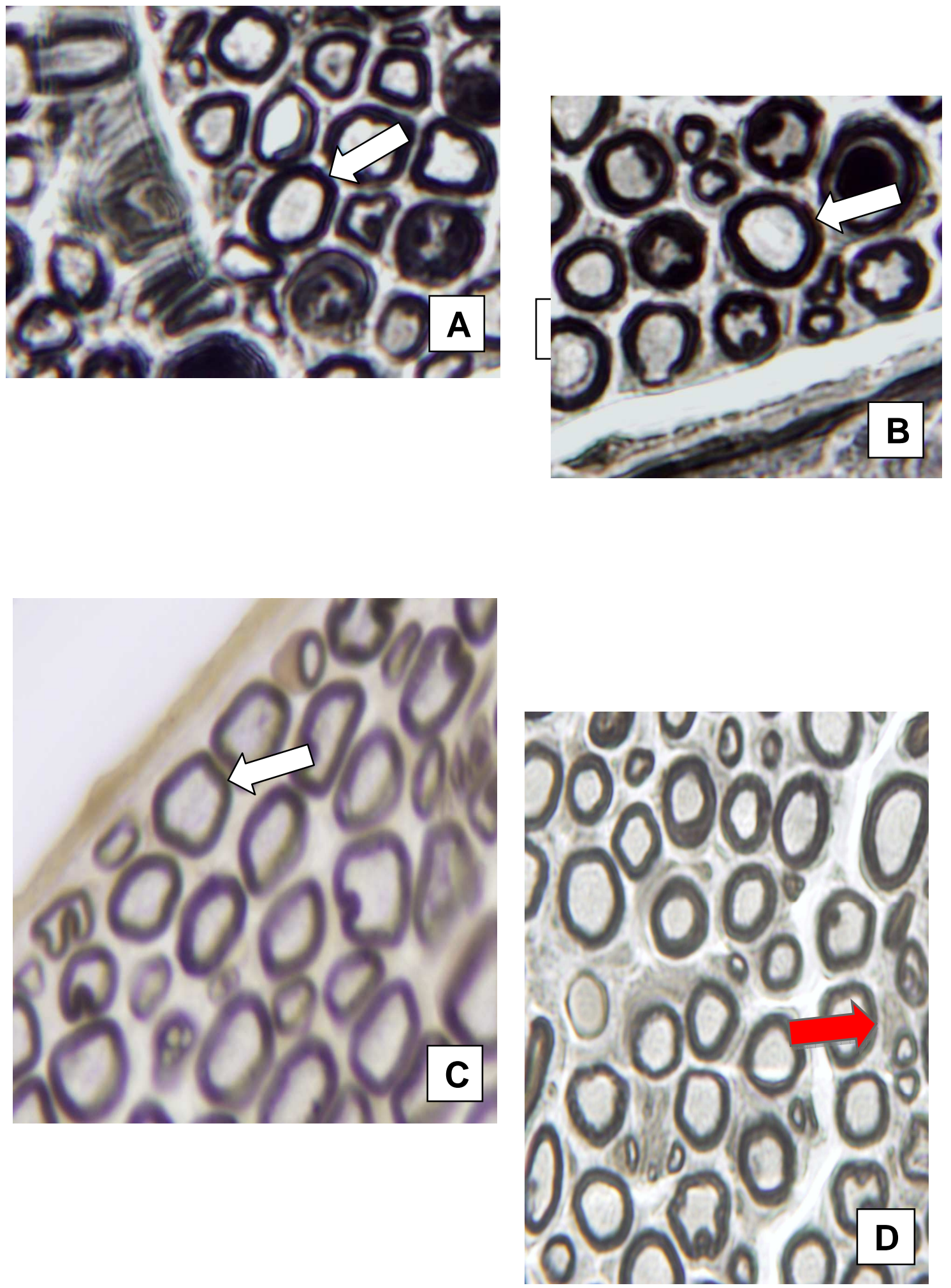

Fig. 25: Em A: GEEPcg150, em B: GEEPsg150, em C: GCI, em D: GCF, note as fibras mielínicas (seta branca), amielínicas (seta vermelha). 


\section{4-Pesos dos animais}

$\mathrm{Na}$ tabela a seguir podemos observar os pesos médios, iniciais e finais, além do ganho de peso em percentagem:

Tabela 1: Distribuição dos ganhos de massa iniciais, médias e finais.

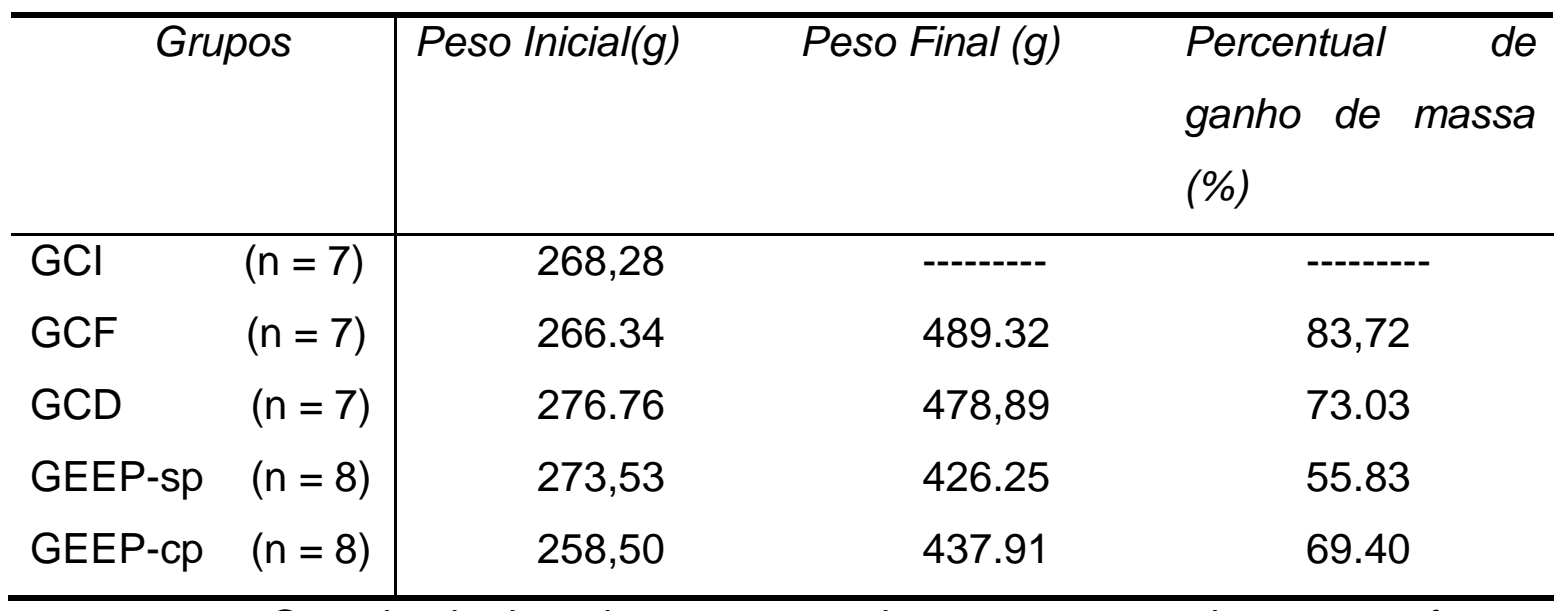

Os animais de todos os grupos tiveram aumento de peso conforme se pode observar na tabela a cima.

\section{5- Autofagia:}

Dois dos animais da pesquisa, um do grupo controle desnervado (GCD) e do grupo experimental enxerto polietileno poroso com preenchimento (GEEP-cp) desenvolveram autofagia após 4 semanas pós-operatória (fig.26).

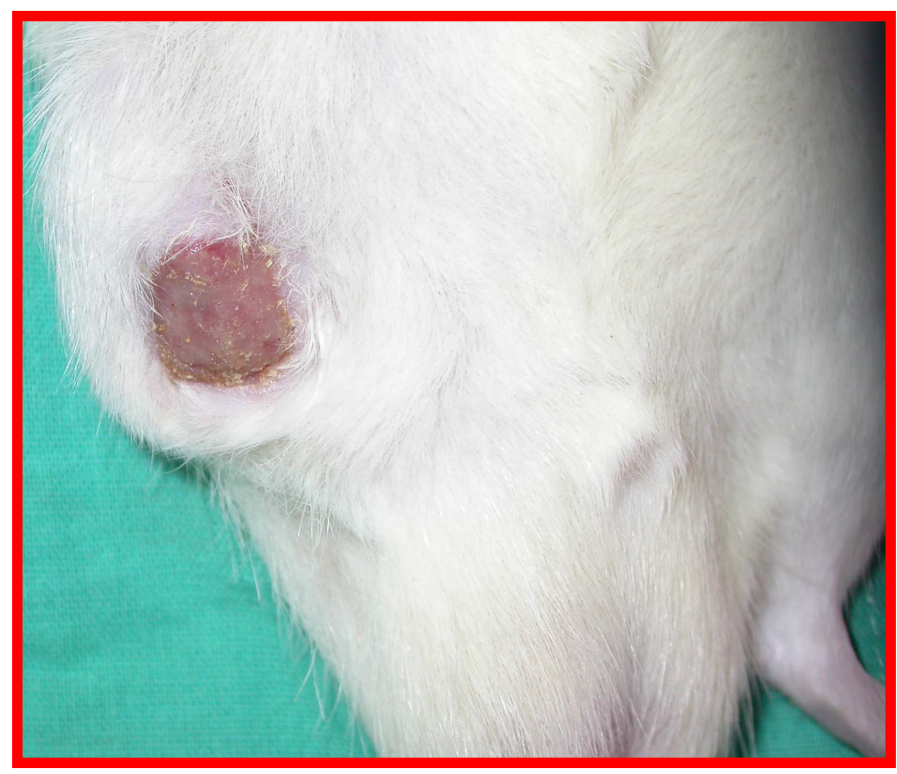




\section{6 - Aspectos morfométricos dos nervos:}

Para a análise dos dados morfométricos, foi utilizado a Análise de Variância e Teste de Tukey para a comparação entre os 5 grupos, sendo adotado nível de significância de $5 \%(p<0,05)$. Grupos com a mesma letra não possuem diferença estatisticamente significante entre si.

Quadro 4 - Dados morfométricos referente ao nervo Isquiático $(n=220)$. Onde: $\mathrm{AF}=$ Área da Fibra, $\mathrm{AA}=$ Área do Axônio, $\mathrm{DF}=$ Diâmetro da Fibra, $\mathrm{DA}=$ Diâmetro do Axônio, $A B=$ Área da Bainha e EB= Espessura da Bainha.

Fig.26: Autofagia do animal do Grupo controle desnervado

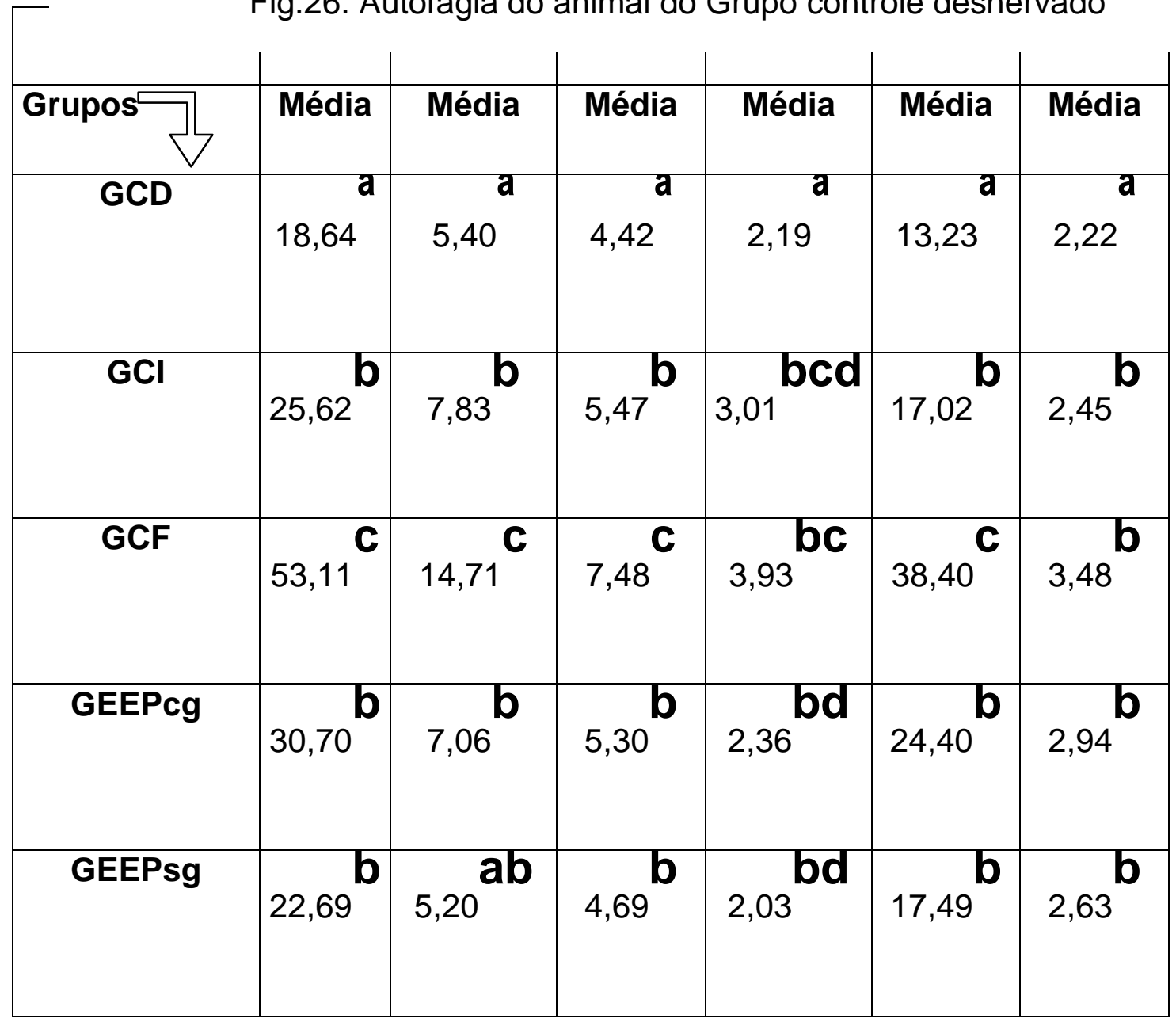




\section{Área das fibras}

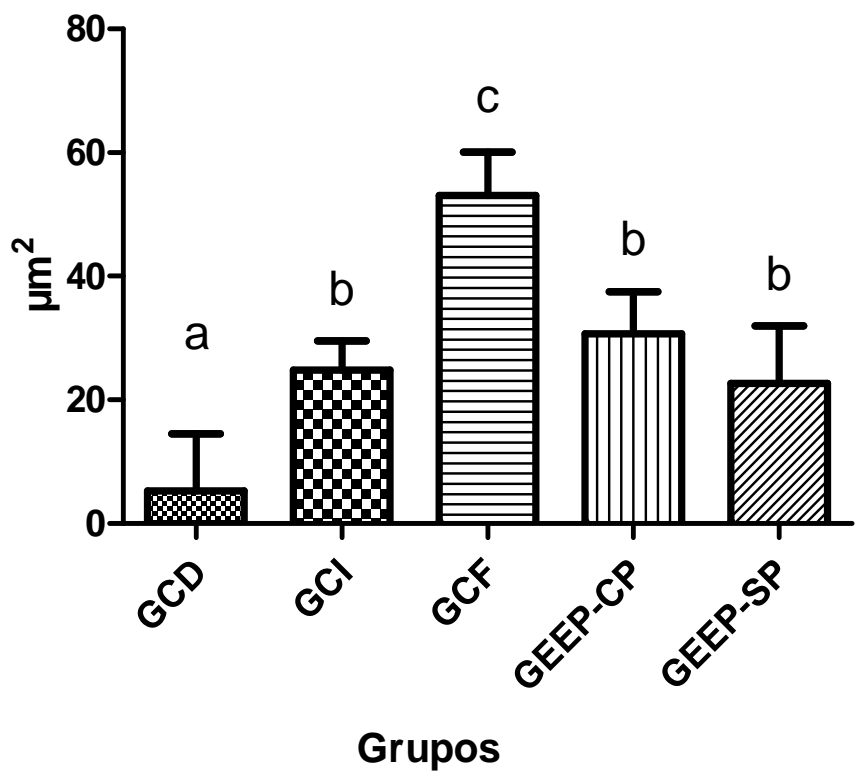

Fig. 27: Representação gráfica da média das áreas das fibras nervosas do nervos Isquiático $(\mathrm{n}=220)$.

\section{Área dos axônios}

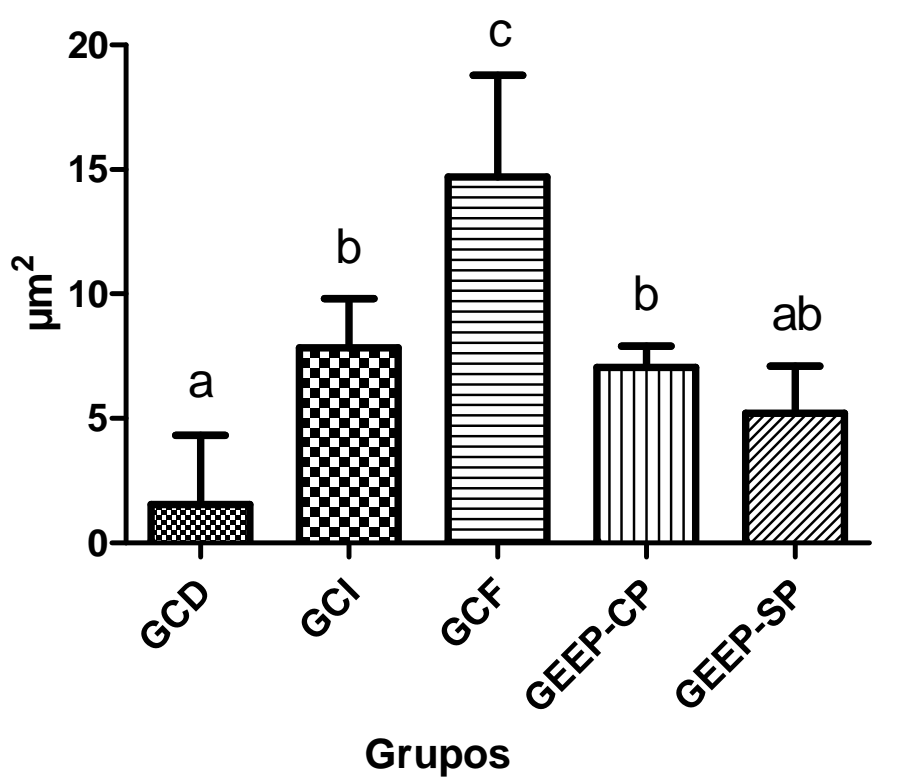

Fig. 28: Representação gráfica da média da área dos axônios do nervo Isquiático $(n=220)$. 
O resultado da morfometria referente à variável - área das fibras nervosas do nervo Isquiático - está representado na figura 27. Podemos observar nos dados que nenhum grupo experimental obteve valor estatisticamente não significante quando comparados com o grupo GCF-150, no entanto, quando comparamos os grupos experimentais entre si, notamos que não possuem valores estatisticamente significantes embora o GEEPcg ter valor maior $30,70 \mu \mathrm{m}^{2}$ contra $22,69 \mu \mathrm{m}^{2}$ do GEEPsg .

No que tange a variável - área dos axônios do nervo Isquiático observada na figura 28 , notamos que nenhum dos grupos experimentais obteve valor estatisticamente não significante quando comparado com o Grupo Controle Final, contudo quando comparados entre si não possuem diferenças estatísticas mesmo que o GEEPcg tenha apresentado valor superior $\left(7,06 \mu \mathrm{m}^{2}\right)$ ao GEEPsg $\left(5,20 \mu \mathrm{m}^{2}\right)$.

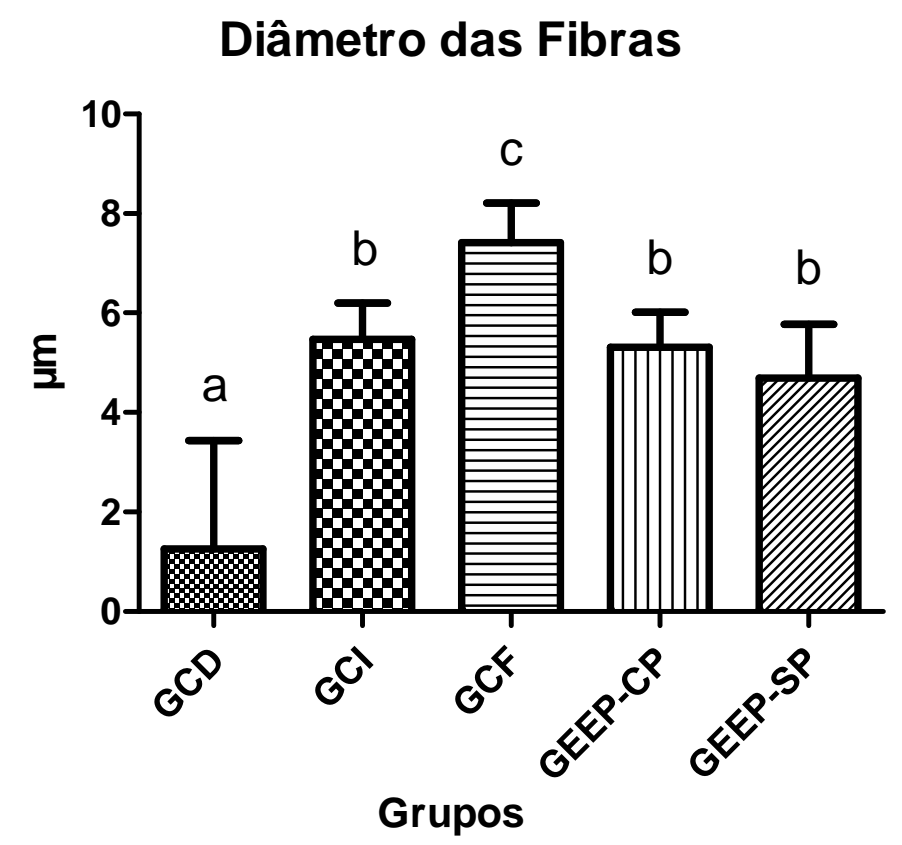

Fig. 29: Representação gráfica da média do diâmetro fibras nervosa do nervo Isquiático $(n=220)$. 
No que diz respeito ao diâmetro das fibras do nervo Isquiático representados na figura 29 , observamos pelos valores mensurados que os grupos experimentais apresentaram resultados estatisticamente diferentes quando comparados com o GCF-150. Todavia, quando analisados entre si, os grupos experimentais não apresentaram valores estatísticos significativos mesmo com valores diferentes entre si (GEEPcg $=5,30 \mu \mathrm{m}$ e GEEPsg $=4,69$ $\mu \mathrm{m})$.

Quanto ao diâmetro dos axônios do nervo Isquiático representados na figura 30, observamos que os grupos experimentais apresentaram diferença significante quando comparados ao Grupo Controle Final, já quando avaliados entre si não representam diferença significantes embora apresentem valores diferentes (GEEPcg $=2,36 \mu \mathrm{m}$ e GEEPsg $=2,06 \mu \mathrm{m}$ ).

\section{Diâmetro dos Axônios}

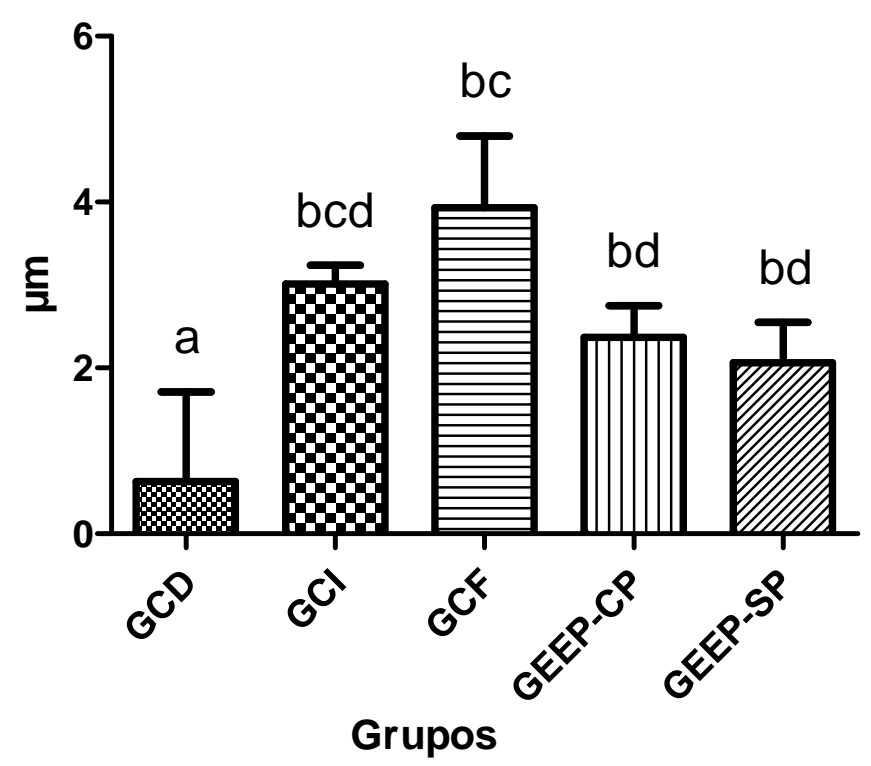

Fig.30: Representação gráfica da média do diâmetro dos axônios (n $=220$ ). 


\section{Área das Bainhas de Mielina}

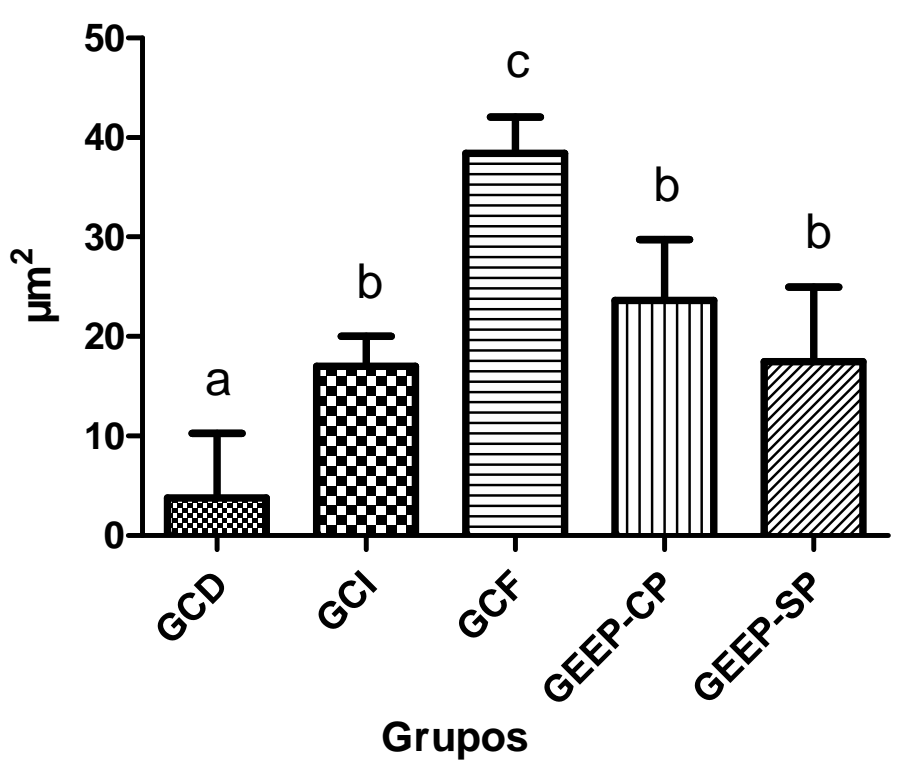

Fig.31: Representação gráfica da área das bainhas de mielina do nervo Isquiático $(n=220)$.

Pelos valores da variável área da bainha de mielina do nervo Isquiático, na figura 31, podemos ressaltar que o GCF apresentou resultados estatisticamente significantes quando confrontados aos grupos experimentais, que por sua vez analisados não apresentam resultados expressivos apesar de diferentes $\left(24,40 \mu \mathrm{m}^{2}\right.$ para GEEPcg e $17,49 \mu \mathrm{m}^{2}$ para GEEPsg).

Avaliando o quesito espessura da bainha de mielina do nervo Isquiático, na figura 32, diferentemente dos outros, não houve diferenças estatísticas entre o GCF $(3,48 \mu \mathrm{m}), \mathrm{GCl}(2,45 \mu \mathrm{m})$, GEEPcg $(2,94 \mu \mathrm{m})$ e GEEPsg $(2,63 \mu \mathrm{m})$. 


\section{Espessura das Bainhas de Mielina}

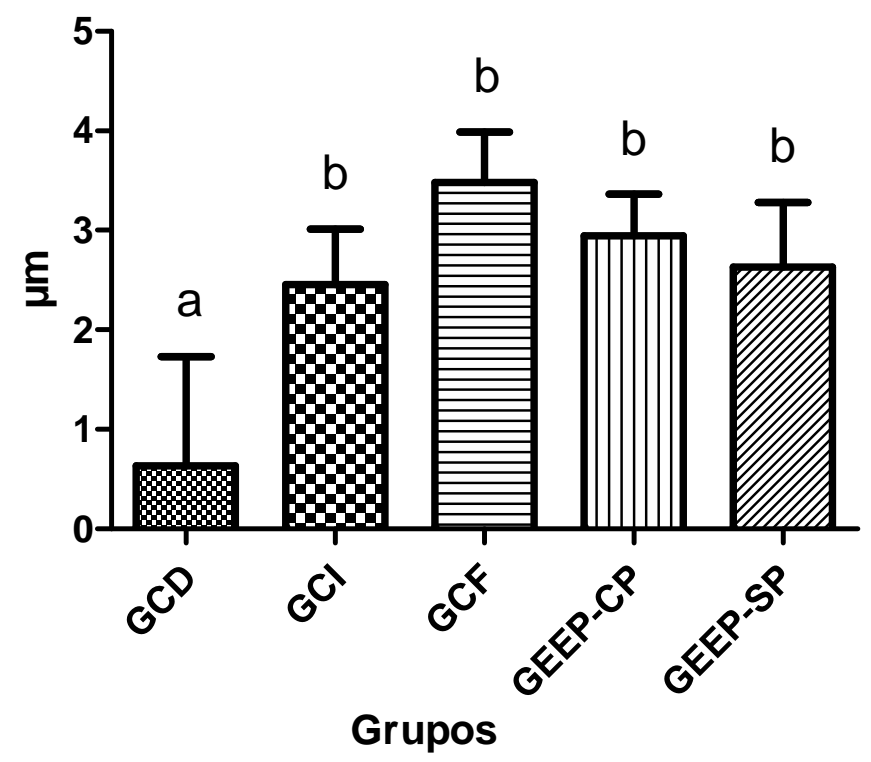

Fig.32: Representação gráfica da Espessura das Bainhas de Mielina do nervo Isquiático $(n=220)$.

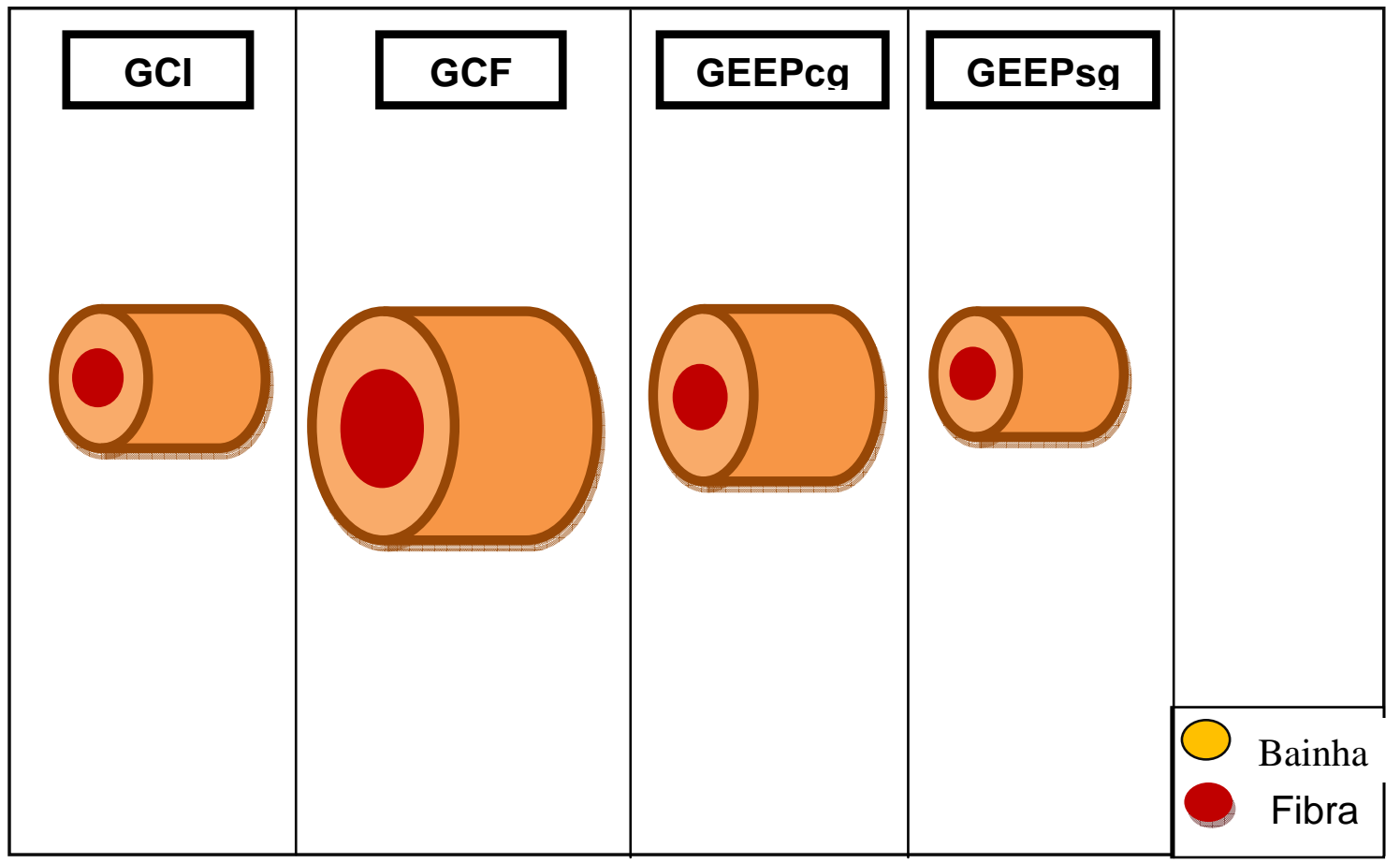

Fig. 33: Imagem representando as fibras nervosas do nervo Isquiático dos grupos GCl, GCF, GEEPcg e GEEPsg da esquerda para direita respectivamente, considerando todas as variáveis possíveis. 


\section{7 - Análise funcional do nervo Isquiático:}

A análise funcional do nervo Isquiático se deu por meio da marcha ou "footprint", valores próximos de -100 referem-se a nervos isquiáticos seccionados, próximos a 0 (zero) referem-se a animais do grupo controle (normais).

Quadro 5: Dados referentes as médias dos valores colhidos das marchas dos animais.

\begin{tabular}{|l|c|}
\hline & Valores das marchas \\
\hline Grupos & Média \\
\hline GCD $(n=3)$ & $-80,97$ \\
\hline GCF $(n=3)$ & $-0,78$ \\
\hline GEEPcg $(n=3)$ & $-75,59$ \\
\hline GEEPsg $(n=3)$ & $-63,50$ \\
\hline
\end{tabular}

A análise dessas variáveis mostrou que os valores médios foram diferentes, especialmente quando comparamos os grupos experimentais ao grupo controle final. $\mathrm{O}$ grupo que mais se aproximou da normalidade foi 0 GEEPsg $(-63,50)$. 
82 4-Resultados 


\section{5 - Discussão}



Com a intenção de obter resultados mais confiáveis, algumas variáveis durante o delineamento do projeto mereceram atenção especial, pois são fundamentais para a padronização dos procedimentos. Os processamentos de todas as amostras seguiram protocolos específicos de acordo com a finalidade do material. Para o processamento dos nervos com finalidades morfométricas, seguiu-se o protocolo do laboratório de Patologia da Faculdade de Odontologia da Universidade de São Paulo (FOB-USP). Além disto, as experiências prévias obtida de trabalhos anteriormente desenvolvidos bem como a infraestrutura do biotério e dos laboratórios onde foram realizadas as técnicas empregadas contribuíram para obtenção de resultados mais confiáveis.

A utilização de ratos como animais experimentais, normalmente se deve ao fato de seu fácil manejo, baixo custo de manutenção e semelhança nos processos de degeneração e regeneração com o dos humanos (FALDINI, 1984; SILVA; LANGONE, 1989; SJOBERG; KANGE, 1989; KLJAVIN; MADISON, 1991; SJOBERG; KANGE, 1989; TERZIS, 1997; KAKINOKI et al., 1997; DAHLIN; LUNDBORG, 2001; MENOVSKY; BEEK, 2001; CASTAÑEDA; KINNE, 2002; BARCELOS et al., 2003; MARTINS et al., 2004; KOTULSKA et al., 2006; ATKINS et al., 2007; TANSEY et al., 2011). Com respeito ao sexo dos animais, foram utilizados apenas machos com intuito de minimizar as variáveis hormonais e circadianas, decorrentes do ciclo estral e ação dos hormônios adenohipofisários. A idade do plantel influencia grandemente, por isto utiliza-se na corrente cientifica, animais jovens que apresentam capacidade regenerativa aumentada. Em nosso trabalho utilizamos ratos machos e jovens, estando de acordo com a maior parte da literatura consultada.

Animais da mesma idade podem apresentar variação de peso antes do experimento. Por esta razão, no dia do procedimento é comum os mesmos serem separados em caixas especialmente confeccionadas, em numero não superior a 5 por compartimento (BARCELOS et al., 2003). Em nosso experimento os animais foram igualmente pesados e separados por caixas.

Os procedimentos cirúrgicos se deram com auxilio de microscópio cirúrgico, haja vista que propiciam maior precisão (BARCELOS et al., 2003; 
MARTINS et al., 2004; KOTULSKA et al., 2006; ATKINS et al., 2007). Na pesquisa em questão utilizou-se o microscópio do tipo DF Vasconcelos.

Os sacrifícios acontecem, normalmente aos 150 dias de pósoperatório, uma vez que as maiores respostas funcionais e histomorfométricas acontecem até a $12^{\text {a }}$ semana, após este período não são encontrados alterações significantes que justifiquem um período superior a este (BARCELOS et al 2003; KOTULSKA et al., 2006). Na pesquisa em questão os sacrifícios aconteceram com 150 dias de pós-operatório para os grupos experimentais

Com respeito ao procedimento anestésico, utiliza-se injeção intramuscular, que é consenso na literatura, todavia ocorre grande variação no sal anestésico, com Tiopental sódico (JEANS; GILCHRIST; HEALY, 2006), Pentobarbital sódico (KAKINOKI et al., 1997; RODRIGUES; SILVA, 2001; RAHAL et al.,2003; BARCELOS et al., 2003; TANIGAWA; SAITO; IIDA, 2005; OZBEK; KURT, 2006; SANANPANICH et al., 2007),associação de ketamina, Xylasine e Atropina (MENOVSKY; JOHAN; BEEK, 2001; BELKAS et al., 2005), associação de Diazapan e Ketamina (MARTINS et al., 2005), Cloridrato de Ketamina (SANDRINI; PEREIRA-JUNIOR; GAY-ESCODA, 2007), associação de Fentanyl, Fluanisone e midazolan (ATKINS et al., 2007), associação de Cloridrato de Tiletamina, associado com Cloridrato de Zolazepam (MORAES et al., 2004; MORAES et al., 2005), em nosso trabalho a técnica anestésica está em conformidade com esses últimos autores.

O nervo isquiático é escolhido pela maioria dos pesquisadores uma vez que apresenta fácil acesso, ser ricamente vascularizado, além de possuir vasos intraneurais semelhantes aos nervos periféricos humanos, ser nervo misto, sensitivo e motor (PAASSEN; MEEK; GRAMSBERGEN, 2005), A presente pesquisa utilizou o nervo isquiático como alvo de suas atenções em concordância com os autores supracitados.

A lesão de escolha para estudo da regeneração é a neurotmese (SEDDON, 1943), por se tratar do estado mais grave e de mais difícil recuperação. Neste tipo de lesão, quando ocorre perda significativa de tecido, há necessidade de tubulização para guiar os brotamentos axonais do coto proximal até o coto distal. As lesões provocas, de acordo com a literatura, 
variaram de $4 \mathrm{~mm}$ (SILVA; LANGONE, 1989) á $25 \mathrm{~mm}$ (KAKINOKI et al., 1997). Os animais das cirurgias desse trabalho sofreram lesões de $10 \mathrm{~mm}$.

A forma em que a lesão é gerada foi objeto de assunto de pesquisa já que pode influenciar nos resultados finais da regeneração, dados indicam que a adesão ou a enxertia, os cotos em ângulo agudo é um método mais eficaz de reparo do nervo que o procedimento normal realizado no ângulo reto (KOTULSKA et al., 2006), em nosso trabalho, a lesão foi provocada em ângulo reto .

A tensão exercida no sítio da sutura do enxerto com o nervo é maléfica ao processo regenerativo, o tecido cicatricial oblitera a luz por onde deverá passar a nova inervação. Por esta razão o tubo de polietileno poroso apresenta comprimento de $12 \mathrm{~mm}$, enquanto que as lesões provocadas limitaram-se a $5 \mathrm{~mm}$. É importante mencionar que após gerar a lesão ocorre uma retração natural, aumentando ainda mais o gap entre os cotos proximal e distal.

Com a evolução da engenharia genética e aprimoramento da cirurgia experimental, o uso de componentes com fatores de crescimento e células tronco, no interior dos tubos biológicos e não biológicos, tem sido cada vez mais comuns (D'ANDREA, 2008). A gordura por apresentar estas características, além de ser facilmente encontradas no sitio cirúrgico podendo ser removida sem prejuízo funcional e estético, esta sendo largamente utilizada. Um dos grupos experimentais com enxerto de polietileno poroso receberam pequenas porções de células adiposas recolhidas in situ.

A utilização de materiais não biológicos sempre apresentaram resultados controversos, entretanto, a literatura atual tem mostrados resultados promissores, com a utilização de materiais a base de vidro, biodegradáveis, biocompatíveis, e sem evidência de uma resposta inflamatória no tecido 10 meses após a sua inserção (GILCHRIST, 1994; JEANS; GILCHRIST; HEALY, 2006). Vários pesquisadores têm focado sobre condutas feitas de polímeros naturais tais como colágeno (ELLIS; YANNAS, 1996; TOBA et al., 2001; TANSEY et al., 2011) , fibronectina (BALDWIN; KREWSON; SALTZMAN, 1996; AHMED; UNDERWOOD; BROWN, 2000), alginato (SUZUKI et al.,2000; HASHIMOTO et al., 2002), agarose (BORKENHAGEN et al., 1998; DILLON et 
al., 1998), e ácido hialurônico (WANG et al., 1998; MOHAMMAD et al., 2000). Silicone tem sido veementemente útil para estudar a regeneração do nervo com resultados interessantes (DUCKER; HAYES, 1968; MERLE et al., 1989; KAKINOKI et al., 1997). Materiais biodegradáveis, como a polilactina (PLA) ou poliglicólico (PGA) (WEBER et al., 2000; EVANS et al., 2002;), ou polifosfoésteres (PHB) (HAZARI et al., 1999); ou ainda Hidroxietil metilmetacrilato poroso, polietileno (SILVA; LANGONE, 1989). Nosso trabalho esta de acordo com a afirmação de que os avanços tecnológicas estão trazendo aumento significativo nos índices de sucesso dos materiais não biológicos.

A utilizaçâo de materiais não biológicos, em especial, os tubos de polietileno poroso, garantem menor invasibilidade cirúrgica uma vez que não necessitam de dois sítios cirúrgicos, a exemplo do que ocorre com os materiais biológicos. Haja vista quando se usa veia invertida ou artéria invertida ocorre abordagem operatória em campo sadio (BARCELOS et al., 2003; BATTISTON, 2005; LUNDBORG, 2005).

Os nervos foram fixados aos tubos com auxilio do fio monofilamentar de nylon 10.0. Isso porque, além de ser economicamente mais viável, apresenta fácil manipulação e é resistente.

Os poros, que certamente foram a grande novidade estrutural dos tubos parecem permitir nutrição de pequenos capilares circunvizinhos ao enxerto de modo a acelerar o processo de regeneração. Outros trabalhos que lançaram mão dos materiais não biológicos desenvolveram tubos sem porosidade (SILVA; LANGONE, 1989; KAKINOKI et al., 1997; TANSEY et al., 2011).

A autofagia ou automutilação podem ser atribuídas à perda de sensibilidade na pata do animal causada pela secção do n. Isquiático no momento do procedimento cirúrgico (BARCELOS et al., 2003). Dos 37 animais pesquisados 2 deles sofreram automutilação, um do Grupo controle desnervado (GCD) e outro do Grupo experimental enxerto com preenchimento (GEEP-cg).

No sacrifício notou-se de alterações na marcha. Além disto, verificamos que na pata onde foi realizado o procedimento operatório ocorreu o fenômeno semelhante ao "Waiters tip hand" ou simplesmente, mão de garçom. 
Esta alteração, acredita-se permanecer, pois as alterações morfofuncionais ocorrem até a décima segunda semana pós-operatória.

As lâminas foram fixadas com tetróxido de Ósmio, metodologia utilizada por vários autores (SUZUKI et al.,2000; HASHIMOTO et al., 2002; BARCELOS et al., 2003; BATTISTON, 2005; LUNDBORG, 2005). Corroborando novamente com os pesquisadores, quanto a análise morfométrica, foram realizadas aferições com o objetivo de obter a área da bainha de mielina e a espessura da bainha.

A coleta das amostras do nervo na região do enxerto se deu no terço médio, estando em conformidade com a literatura (RODRIGUES e SILVA, 2001; BARCELOS, 2003).

A neovascularização nos enxertos nervosos é fundamental no processo regenerativo (FERRARI et al., 1999; RODRIGUES e SILVA, 2001) .Os vasos no interior dos tubos demonstraram trazer benefícios, sendo potencialmente úteis para a reparação de nervos periféricos em humanos (KAKINOKI et al., 1997). Por estar de acordo com estas assertivas que nos tubos de polietileno foram realizados poros com auxílio de laser perfurante.

A utilização de tubos sintéticos pareceram formar uma armação primária para orientar a migração de fibroblastos, células de Schwann e eventualmente processo axonal (SJOBERG; KANGE, 1989; KLJAVIN; MADISON, 1991). De modo que em nossa pesquisa não verificamos a presença de axônios externamente aos limites dos tubos de polietileno poroso.

Em nossas observações histológicas do terço médio dos enxertos e do terço médio do coto distal, de todos os grupos, constatamos a presença de fibras nervosas mielínicas e amielínicas heterogêneas, a neoformação de perineuro e a organização intraneural de fascículos com tamanhos e números variados concordando com os autores consultados (FERRARI et al., 1999; RODRIGUES e SILVA, 2001).

Em nosso experimento, notamos axônios em regeneração, em todos os animais de todos os grupos experimentais. Sugeriu-se que os axônios cresceram do coto proximal do nervo ciático, atravessaram o espaço intersegmentar e atingiram o coto distal deste nervo, pois, em todas as 
variáveis analisadas foram maiores os parâmetros no terço médio do enxerto do que na região do coto distal.

Levando em conta a análise funcional dos nervos estudados, verificamos que apesar de estatisticamente não relevante, o grupo GEEPsg, mostrou melhores resultados quando comparado ao outro, o GEEPcg. Contudo, se verificarmos o desenvolvimento proporcional da área do axônio em relação à espessura da bainha de mielina, o índice de mielinização (ROQUE, 2008), encontramos melhores resultados no segundo grupo mencionado. Duas hipóteses nesse caso podem ser creditadas, a primeira é que de fato os achados funcionais não apresentaram relevância para serem considerados quando comparados os grupos experimentais, o segundo é que a análise da proporção área vs espessura, apesar de ter sido mais bem sucedida no grupo com preenchimento com tecido adiposo, não ser relevante, certamente novos trabalhos nessa linha de pesquisa deverão ser realizados.

$\mathrm{Na}$ morfometria quando comparamos as variáveis do nervo Isquiático, notamos que o grupo GEEPcg obteve maior desempenho em todas elas. E na variável espessura da bainha de mielina, obteve resultado estatisticamente igual ao grupo controle final (GCF), corroborando com ROSA-JUNIOR (2010). Analisando os resultados em suas variáveis, notamos que a presença do enxerto autólogo de tecido adiposo pareceu contribuir sensivelmente nos resultados morfométricos em especial nas variáveis área e espessura da bainha concordando o mesmo.

Certamente, existem mais perguntas que respostas para a avaliação da regeneração de nervos periféricos, e é exatamente atrás desses questionamentos que a maioria dos autores verificados vem se debruçando. Entretanto, atenção especial deve ser dado a utilização de células tronco na regeneração dos tecidos. A utilização de tubos não biológicos mostrou-se promissora, haja vista que minimiza os traumas cirúrgicos, uma vez que reduz uma abordagem cirúrgica. 
6 - Conclusões 

Baseado na análise da literatura nacional e internacional, no projeto de pesquisa desenvolvido pelo Departamento de Ciências Biológicas, disciplina de Anatomia, podemos concluir que:

1) O enxerto de Polietileno poroso mostrou-se benéfico para a regeneração do nervo Isquiático;

2) Apesar de apresentar consistência semirrígida o polietileno mostrou ter resistência a pressões já que não foi observado colapso estrutural do mesmo;

3) A utilização da gordura como fator trófico na regeneração pareceu ser favorável quando comparado a não utilização;

4) O emprego de materiais não biológicos é favorável do ponto de vista cirúrgico, uma vez que reduz o número de abordagens cirúrgicas;

5) O grupo GEEPcg mostrou resultados morfométricos mais próximos ao grupo controle final. 
94 6-Conclusões 
Referências 

Al-qattan MM. Terminolateral neurorrhaphy: review of experimental and clinical studies, J Reconstr Microsurg 2001;17:99-108.

Ansselin $A D$, Fink $T$, Davey DF. Peripheral nerve regeneration though nerve guides seeded with adult Schwann cells. Neuropath Appl Neurol 1997; 23:387-398.

Artico M, Cervoni L, Nucci F, Giuffré R. Birthday of peripheral nervous system surgery: the contribution of Gabriele Ferrara (1543-1627). Neurosurgery. 1996;39(2):380-2; discussion 382-3.

Atikins S, Loescher A, Boissonade FM, Smith KG, Occleston N, O'kane S, et al. Interleukin-10 reduces scarring and enhances regeneration at a site of sciatic nerve repair. . J Peripher Nerv Syst 2007;12:269-276.

Atikins S, Smith KG, Loescher AR, Boissonade FM, Ferguson MWJ, Robinson PP. The effect of antibodies of TGF- $\beta 1$ e TGF- $\beta 2$. J Peripher Nerv Syst 2006; 11:286-293.

Atolini Junior, N. et al. Paralisia facial periférica: incidência das várias etiologias num ambulatório de atendimento terciário. Arq. Int. Otorrinolaringol., São Paulo, 2009; 2(13):167-171.

Baldwin KM, Haddad F. Effects of different activity and inactivity paradigms on myosin heavy chain gene expression in striated muscle. J Appl Physiol 2001;90:345-357

Batista KT, Almeida CEF. Epidemiologia das lesões traumáticas tardias de nervo periférico do membro superior. Rev. Soc. Bras. Cir. Plást. 2008; 23(1):26-30. 
Battiston BB, Pierangelo G, Vigasio A, Brunelli G. Experimental investigation of cross-nerve transfers relating to repair of brachial plexus avulsion injuries. Microsurgery 1990;2(11):91-94.

Barcelos AS, Rodrigues AC, Silva MD, Padovani CR. Inside-out vein graft and inside-out artery graft in rat sciatic nerve repair. Microsurgery 2003; 23(1):66-71.

Becker CM, Gueuning CO, Graff GL. Sutures of fibrine glue for divided rat nerves. Journal of Reconstructive Microsurgery. 1984; 2(1):139-45.

Belkas JS, Munro CA, Shoichet MS, Midha R. Peripheral nerve regeneration though a synthetic hydrogel nerve tube. Restor Neurol Neurosci. 2005; 23:19-29.

Beris A, Lykissas M, Korompillias A, Mitsionis. End-to-side nerve repair in peripheral nerve injury. J Neurotrauma 2007;5(24):909-16.

Borkenhagen M, Clemence JF, Slgrist H, Aebischer P. Three-dimensional extracellular matrix engineering in the nervous system. J Biomed Mater Res 1998;40:392-400.

Bosch, E. P.; Smith, B. K. Disorders of peripherical nervs. In: BRADLEY, W. G. et al. (Ed.). Neurology in Clinical Pratice: Principles of diagnosis and management. 4. ed. London: Butterworth Heinemann, 2005:2299-2394.

Boyd JG, Gordon T. A dose-dependent facilition and inhibition of peripheral nerve regeneration by brain-derived neurotrophic factor. Eur $\mathrm{J}$ Neurosci 2002;15:613-626.

Brackmann DE. Porous polyethylene prosthesis: continuing experience. Ann Otol Rhinol Laryngol 1986;95:76-77. 
Bryan DJ, Wang KK, Chakalis-Haley DP. Effect of Shwann cells in the enhancement of peripheral-nerve regeneration. $J$ Reconstr Microsurg 1996;12:439-445.

Brown RE, Erdmann D, Lyons SF, Suchy H. The use of cultured Schwann cells in nerve repair in a rabbit hind-limb model. $J$ Reconstr Microsurg 1996;12:149-152.

Brunelli GA, Vigasio A, Brunelli GR. Different conduits in peripheral nerve surgery. Microsurgery. 1994;15(3):176-8.

Cai J, Peng X, Nelson KD, Eberhart R, Smith GM. Permeable guidance channels containing microfilament scaffolds enhance axon growth and maturation. J Biomed Mater Res A. 2005; 75(2):374-86.

Cartarozzi LP, Zanon RG, Oliveira ALR. Regeneração nervosa periférica após esmagamento do nervo ciático e tratamento com interferon beta. Departamento de Anatomia, Instituto de Biologia - UNICAMP; CNPq.

Castaneda F, Kinne RK. Omental graft improves functional recovery of transected peripheral nerve. Muscle Nerve 2002; 26(4):527-32.

Cunha AS, Lemos SPS, Silva CF, Barros-Filho TP, Costa MP, Ferreira MC. Utilização da veia glicerolada na regeneração neural. Estudo experimental em ratos. ACTA ORTOP BRAS 2007; 4:210-213.

D'andrea F, De Francesco F, Ferraro GA, Desiderio V, De Rosa, Papaccio G. Large-scale production of human adipose tissue from stem cells: a new tool for regenerative medicine and tissue banking. Tissue Eng Part C Methods 2008; 14(3):233-42.

Dahlin LB, Lundborg G. Use of tubes in peripheral nerve repair. Neurosurg Clin N Am 12(2):341-352. 
De Sá, M. The end to side pheripheral nerve repair functional and morphometric study using the peroneal nerve of rats. J. Neurosci. Methods 2004; 1(136):45-53.

Dillon GP, Yu XJ, Bellamkonda RV. The polarity and magnitude of ambient charge influences three-dimensional neurite extension from DRGs. J Biomed Mater Res 2000;51:392-400.

Dourado E, Gomes ACA, Gomes PFS, Ribeiro TPA. Técnicas microcirúrgicas de reparação nervosa: procedimentos convencionais e alternativos. Rev Cir Traumatol BMF 2003; 3(2):49-54.

Dowsing BJ, Hayes A, Bennet TM, Morrison WA, Messina A. Effects of LIF dose and laminina plus fibronectina on axotomized sciatic nerves. Muscle nerve 2000;23:1353-1364.

Ducker TB, Hayes GJ. Experimental improvements in the use of silastic cuff for perioheral nerve repair. J Neurosurg 1968; 28:582-587.

Evans GR, Brandt K, Katz S, Chauvin P, Otto L, Bogle M, et al. Bioactive poly (L-lactic acid) conduits seeded with Schwann cells for peripheral nerve regeneration. Biomaterials 2002;23:841-848.

Faldini A, Puntoni P, Magherini PC. Comparative neurophysiological assessments of nerve sutures perfomed by microsurgical methods and with fibrin glue: experimental study. Ital. Jnl. Orthop Traumatol 1984;10:527-32.

Fawcett JW, Keynes RJ . Fawcett JW, Keynes RJ . Muscle basal lamina: a new graft material for peripheral nerve repair. J Neurosurg. 1986 ;65(3):35463. 
Ferrari F, Rodrigues AC, Malvezzi CK, Silva MDP, Padovani CR. Inside-out vs standard vein graft to repair a sensory nerve in rats. Anat Rec 1999; 256 : 227-232.

Fields RD, Le Beau JM, Longo FM, Ellisman MH. Nerve regeneration through artificial tubular implants. Progr Neurobiol 1989; 33: 87-137.

Fu Sy, Gordon T. Contributing factors to poor functional recovery after delayed nerve repair: Prolonged denervation. J Neuroc 1995,15(5):38863895.

Geuna S, Papalia I, Tos P. End-to-side (terminolateral) nerve regeneration : A challenge for neuroscientists coming from na intringuing nerve repair concept. Brain Res Rev 2006; 52: 381-88.

Gilchrist $T$, Jeans La, Healy D. Peripheral nerve repair by means os a flexible biodegradable glass fibre wrap: A comparison with microsurgical epineural repair. J Plastic Recons Aesth Surgery 2006;60:1302-1308.

Girolami U, Anthony Dc, Frosh MP, Nachemson AK. Tissue specifity in nerve regeneration. Scandinavian J Plast Recons Surgery 1986;20:279283.

Grant GA, Goodkin R, Kliot M. Evaluation and surgical management of peripheral nerve problems. Neurosurgery. 1999;44(4):825-39; discussion 839-40.

Haldlock T, Sundback C, Hunter D, Cheney M, Vacanti JP. A polymer foam conduit seeded with Schwann cells promotes guided peripheral nerve regeneration. Tissue Eng 2000;6:119-127.

Hashimoto T, Suzuki Y, Kitada M, Kataoka K, Wu S, Suzuki K, et al. Peripheral nerve regeneration though alginate gel: Analysis of early 
outgrowth and late increase in diameter of regenerating axons. Exp Brain Res 2002;146:356-368.

Hazari A, Wiberg M, Johansson-Ruden G, Green C, Terenghi G. A resorbable nerve conduits as an alternative to nerve autograft in nerve gap repair. Br J Plast Surg 1999;52:653-657.

Heijke GCM, Klopper PJ, Van Doorn IBM, Baljet B. Processed porcine collagen tubulization versus conventional suturing in peripheral nerve reconstruction: an experimental study in rabbits. Microsurgery 2001;21:8495 ;

Hu J, Zhu QT, Liu XI, Xu Y, Zhu JK. Repair of extended peripheral nerve lesions in rhesus monkeys using acellular allogenic nerve grafts implanted with autologous mesenchymal stem cells. Exp Neurol 2006; 204(2):658-66.

Hudson AR, Hunter D, Kline DG, Bratton BR. Hudson AR, Hunter D, et al. Histological studies of experimental interfascicular graft repairs. J Neurosurg. 1979;51(3):333-40.

Jeans LA, Gilchrist T, Healy D. Peripheral nerve repair by means of a flexible biodegradable glass fibre wrap: A comparison with microsurgical epineurial repair. J Plast Reconst Aesthet Surg 2007; 60(12):1302-8.

Junqueira LC, Carneiro J. Histologia Básica. São Paulo: KOOGAN;11ํㅡㄹ ed: 2009.

Kakinoki R, Nishijima N, Ueba Y, Oka M, Yamamuro T, Nakamura T. Nerve regeneration over a $25 \mathrm{~mm}$ gap in rat sciatic nerves using tubes containing blood vessels: the possibility of clinical application. Int Ortop 1997; 21:332336. 
Kljavin IJ, Madison RD. PNS Axonal regeneration within tubular prosthesis: Effects of laminina and collagen matrices on cellular ingrowth. Cells Materialls 1991; 1:17-28.

Kendall FPI. Músculos: provas e funções. 5. ed. São Paulo, SP: Manole, 2007.

Kostakoglu N. Motor and sensory reinnervation in the hand after an end-toside median to ulnar nerve coaptation in the forearm, Br J Plast Surg 1999; 52:404-407.

Kotulska K, Marcol W, Larysz-Brysz M, Tendera Z, Malinowska-Kolodziej I, Slusarczyk W, et al. Effect of oblique nerve grafting on peripheral nerve regeneration in rats. Microsurgery 2006;26:579-584.

Lacanna, S. N. Entubulation of sciatic nerve of rats with poly-l lactide-co plactide. J. Bras. Neurocirurg 2008;3(19):37-40.

Lavrador RO, Buti M, Navarro X. Influence of collagen and laminin gels concentration on nerve regeneration after ressection and tube repair. Exp Neurol 1998;149:243-252.

Lech, O. Princípios básicos. In PARDINI AGJ. Cirurgia da mão: Lesões não traumáticas. Rio de Janeiro: Medsi 1990;1-33.

Lemos SPS. Nervo alógeno conservado em glycerol na regeneração de nervos periféricos: estudo experimental em ratos. Faculdade de Medicina, Universidade de São Paulo, São Paulo (SP); 2008.

Lundborg G. Chronic nerve compression. In: Lundborg G (ed) Nerve injury and repair, 2 nd edn. Churchill Living-stone 2005.

Machado A. Neuroanatomia functional. 2a Ed: Atheneu, São Paulo; 2004.

Madison RD, Archilbald SJ. Point sources of Schwann cells result in growth into a nerve entubulation repair site in the absence of axons: Effects of freeze-thawing. Exp Neurol. 1994;128(2):266-75. 
Magill CK, Tong C, Kawamura D, Hayashi A, Hunter DA, Parsadanian A, et al. Reinnervation of the Tibialis Anterior Following Sciatic Nerve Crush Injury: A Confocal Microscopic Study in Transgenic Mice. Exp Neurol. 2007; 207(1): 64-74.

Martins SF. Mecanismos básicos da regeneração de nervos. Arq. Bras. Neurocir., São Paulo, 2005;1(24):20-25.

Martins SR, Siqueira MG, Silva CF, Godoy BO, Plese JPP. Electrophysiological evaluation of sciatic nerve regeneration rat, with use of suture, fibrin glue or combination of both techniques. Arq Neuropsiquiatr 2005; 63 (3-A):601-604.

Mazzer PYCN. Avaliação qualitativa e quantitativa das lesões agudas por esmagamento do nervo isquiático do rato. Acta Ortop. Bras 2006;4(14): 220-225.

Mennen U. End-to-side nerve suture in clinical practice, Hand Surg 2003; 8:33-42.

Menovsky T, Beek J. Laser, fibrin glue, or suture repair of peripheral nerves: a comparative functional, histological, and morphometric study in the rat sciatic nerve. J Neurosurg 2001;95:694-699.

Merle M, Dellon AL, Campbell JN, Chang PS. Complications from silicone polymer entubulation of nerves. Microsugery 1989;10:130-133.

Mohammad JA, Warnke PH, Pan YC, Shenaq S. Increased axonal regeneration thourgh a biodegradable amnionic tube nerve conduit: Effect of local delivery and incorporation of nerve growth factor-hyaluronic acid media. Microsurgery 2000;44:59-64. 
Monte-Raso, V. V.. Os efeitos do ultra-som terapêutico nas lesões por esmagamento do nervo ciático em ratos: análise funcional da marcha. Rev. Bras. Fisioter., São Carlos 2006;1(10):113-119.

Moraes JRE, Camplesi AC, Correia PHA, Shimano AC, Ferraro GC, Moraes FR. Snake venom derived fibrina adhesive in dog uterine healing. Biomechanical study 2005;2(11):129-142.

Moraes JRE, Correia PHA, Camplesi AC, Moraes FR. Experimental use of fibrin glue derived from snake venon in non-pregnant canine uterus. J Venom Anim Incl Trop Dis 2004; 2(10):133-143.

Moraes, LHR. A reinervação do músculo extensor longo dos dedos (EDL) de ratos (Rattus Norvegicus). Seria influenciada pelo uso do laser de baixa potência e do tecido adiposo na técnica de tubulização (dissertação). Bauru (SP): Faculdade de Odontologia de Bauru, Universidade de São Paulo; 2010.

Moy OJ, Peimer CA, Koniuch MP. Fibrin seal adhesive versus nonoabsorable microsuture in peripheral nerve repair. The Journal of Hand Surgery 1988; 2(13):273-8.

Murray, B. Trauma of the nervous system: Pheripheral nerve trauma. In: BRADLEY, W. G. et al. (Ed.). Neurology in Clinical Pratice: Principles of diagnosis and management. 4. ed. London: Butterworth Heinemann, 2005: 1179-1198.

Oliveira Ef, Mazzer N, Barbieri CH, Delbel EA. The use of a muscle graft to repair a segmentary nerve defect: An experimental study using the sciatic nerve of rats as model. J Neurosci Methods. 2004;133(1):19-26. 
Ozbek S, Kurt A. Simultaneous end-to-side coaptations of two severed nerves to a single healthy nerve in rats. J Neurosurg Spine 2006;4:43-50.

Pan HC, Yang DY, Ho SP, Sheu MI, Chen CJ, Hwang SM, et al. Escalated regeneration in sciatic nerve crush injury by the combined therapy of human amniotic fluid mesenchymal stem cells and fermented soybean extracts, Natto. J Biomed Science 2009; 23(8):16:75.

Pellegrino C, Franzini C. An electron microscope study of denervation atrophy in red and white skeletal muscle fibers. J Cell Biol. 1963;17(2):32749.

Rahal SC, Amaral MSP, Pai VD, Barraviera SRCS, Caporali EHG, Crocci AJ. Effect of fibrin glue derived from snake venom on the viability of autogenous Split-thickness skin graft. J Venom Anim Toxins Incl Trop Dis 2004;2(10):161-172.

Ramón Y Cajal S. Degeneration and regeneration of nervous system. London: Oxford University Press 1928.

Rodrigues AC, Pai VD, Mota DI, Silva MDP, Padovani. Contribuição ao estudo das unidades motoras do músculo pectíneo do gato (felis domestica). Rev Bras Ciên Morfol 1994;11(2):149-158.

Rodrigues AC, Silva MDP. Inside-out versus standard artery graft to repair a sensory nerve in rats. Microsurgery 2001; 21:102-107.

Rosa-Junior, GM. Enxerto venoso preenchido com gordura no reparo de nervo periférico: Uma nova proposta.(dissertação). Bauru (SP): Faculdade de Odontologia de Bauru, Universidade de São Paulo; 2010.

Roque DD. Enxerto venoso ao avesso e normal, com ou sem preenchimento de músculo, em regeneração nervosa de ratos. 2008. 129f. Tese (Doutorado em bases gerais de cirurgia) - Faculdade de Medicina, Universidade Estadual Paulista, Botucatu. 
Rovak JM, Cederna PS, Kuzon WM. Terminolateral neurorrhaphy: a review of the literature, J Reconstr Microsurg 2001.17:615-624.

Samii M, Koerbel A, Safavi-Abbasi S, Rocco F, Samii A, Gharabaghi A. Using and end-to-side interposed sural nerve graft for facial nerve reinforcement after vestibular schwannoma resection. J Neurosug 2006; 105:920-923.

Sahenk Z, Seharaseyon J, Mendell JR. CNTF potenciates peripheral-nerve regeneration. Brain Res 1994;655:246-250.

Sananpanich K, Galea M, Morrison WA, Messina A. Quantitative characterization of regenerating axons after end-to-side and end-to-end coaptation in a rat brachial plexus model: A retrograde tracer study. J Neurotrauma 2007; 24(5):864-875.

Sandrini FAL, Pereira -Junior ED, Gay-Escoda C. Rev Bras Otorrinolaringol 2007; 73(2):198-201.

Sawamura $\mathrm{Y}$, Abe H. Hypoglossal - facial nerve side-to-end anastomosis for preservation of hypoglossal function: Results of delayed treatment with a new technique. J. Neurosurg 1997;86:203-6.

Seddon HJ. Three types of nerve injury. Brain, Oxford, 1943(66):37-288;

Silva CF. Addition of nerve growth factor to the interior of a tubular prosthesis increases sensory neuron regeneration in vivo. Brazilian $\mathrm{J}$ Med Biol Res 1989; 22: 691-94.

Silva JB, Gehlen D, Roman JA, Menta C, Atkinson EA, Machado DC, et al. Bone marrow and platelet-rich plasma stem cells effects on nervous regeneration and functional recovery in an acute defect model of rats' peripheral nerve. Acta Ortop Bras 2006; 14(6):273-75.

Siqueira R. Lesões nervosas periféricas: uma revisão. Rev Neurocienc 2007;15/3:226-233. 
Spector JG, Lee P, Derby A, Frierdich GE, Neises G, Roufa DG. Rabbit facial nerve regeneration in NGF-containing silastic tubes. Laryngoscope. 1993;103(5):548-58.

Suematsu N. Tubulation for peripheral nerve gap: Its history and possibility. Microsugery 1989;1(10):71-74.

Sunderland S. Nervios perifericos y sus lesions. 2a ed: Salvat, Barcelona; 1985.

Suzuki Y, Tanihara M, Ohnishi K, Hashimoto T, Endo K, Nishimura Y. Reconstruction of rat peripheral nerve gap with-out using freeze-dried alginate gel. J Biomed Mater Res 2000;49:528-533.

Tanigawa N, Saito T, Ogawa K, lida H. Origin of regenerated axons in nerve bypass grafts. J Neurotrauma 2005; 22(5):605-612.

Tansey KE, Seifert JL, Botterman B, Delgado MR, Romero MI. Peripheral Nerve Repair Through Multi-Luminal Biosynthetic Implants. Ann Biomed Eng. 2011; 24:211-15.

Terzis JK, Sun DD, Thanos PK. History and basic science review: past, present, and future of nerve repair. J Reconstr Microsurg 1997;13:215- 225.

Tham, S. K. e Morrison, W. A. Motor collateral sprouting through an end-toside nerve repair, J Hand Surg [Am] 1998; 23:844-851.

Timmer M, Robben S, Muller-Ostermeyer F, Nikkhah G, Grothe C. Axonal regeneration across long gaps in silicone chambers filled with Schwann cells overexpressing high molecular weight FGF-2. Cell Transplantation 2003;12:265-277.

Urbaniak JR. Fascicular nerve suture. Clinical Orthopaedics and related research. 1982;163:57-64. 
Viterbo F, Faleiros HRP. Técnicas de neurorrafia. In: Mélega JM. Cirurgia plástica: Fundamentos e Arte. Medsi: Rio de Janeiro 2002;477-483.

Xiong G, Ozaki N, Sugiura Y. Transplanted embryonic spinal tissue promotes severed sciatic nerve regeneration in rats. Arch Histol Cytol 2009; 72 (2):127-138.

Zhang F, Fischer KA. End-to-side neurorrhaphy. Microsurgery 2002; 22:122-127.

Yan JG, Matloub HS, Sanger JR, Zhang LI, Riley DA, Jaradeh SS. A modified end-to-side method for peripheral nerve repair: large epineurial window helicoid technique versus small epineurial window standard end-toside technique, J Hand Surg [Am] 2002;27:484-492.

Yoshitani M , Fukuda S, Itoi S, Morino S, Tao H, Nakada A, et al. Experimental repair of phrenic nerve using a polyglycolic acid and collagen tube. J Thorac Cardiovasc Surg. 2007;133(3):726-32.

Walker Jc, Brenner MJ, Mackinnon SE, Winograd JM, Hunter DA . Effect of perineurial window size on nerve regeneration, blood-nerve barrier integrity, and functional recovery, J Neurotrauma 2004;21:217-227.

Wang KK, Nemeth IR, Seckel BR, Chakalis-Haley DP, Swann DA, Kuo JW, et al. Hyaluronic acid enhances peripheral nerve regeneration in vivo. Microsurgery 1998;18:270-275.

Weber RA, Breidenbach WC, Brown RE, Jabaley ME, Mass DP. A randomized prospective study of poluglicolic acid conduits for digital nerve reconstruction in humans. Plast Reconstr Surg 2000;106:1036-1045.

Wells MR, Kraus K, Batter DK, Blunt DG, Weremowitz J, Lynch SE, et al. Gel matrix vehicles for growth factor application in nerve gap injuries repaired with tubes: A comparison of biomatrix, collagen and methylcellulose. Exp Neurol 1997;146:395-402. 
110 Referências 